Portland State University

PDXScholar

$11-1-1993$

\title{
The Times, Trial, and Execution of David McLane: The Story of an American Spying in Canada for the French in 1796-1797
}

Mark Allen Thorburn

Portland State University

Follow this and additional works at: https://pdxscholar.library.pdx.edu/open_access_etds

Part of the Canadian History Commons

Let us know how access to this document benefits you.

Recommended Citation

Thorburn, Mark Allen, "The Times, Trial, and Execution of David McLane: The Story of an American Spying in Canada for the French in 1796-1797" (1993). Dissertations and Theses. Paper 4649.

https://doi.org/10.15760/etd.6533

This Thesis is brought to you for free and open access. It has been accepted for inclusion in Dissertations and Theses by an authorized administrator of PDXScholar. Please contact us if we can make this document more accessible: pdxscholar@pdx.edu. 


\begin{abstract}
OF THE THESIS OF Mark Allen Thorburn for the Master of Arts in History presented November 1, 1993.

Title: The Times, Trial, and Execution of David Mclane: The story of an American Spying in Canada for the French in $1796-1797$.
\end{abstract}

APPROVED BY MEMBERS OF THE THESIS COMMITTEE:
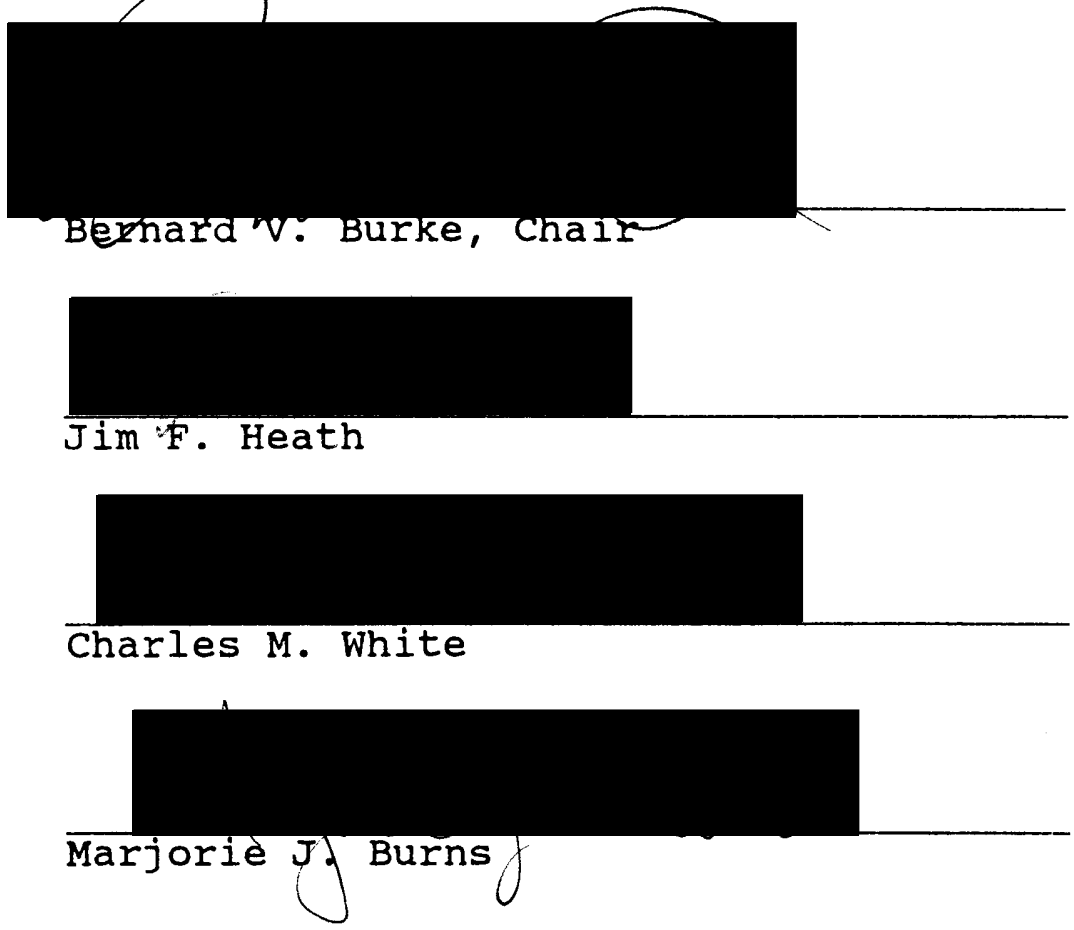

The thesis primarily examines the 1797 trial of David Mclane in Quebec City for spying, the steps taken by the British authorities to ensure a conviction, and McLane's activities in 1796 and 1797 in Vermont and 
Lower Canada on behalf of the French Minister to the United states, Pierre Adet. McLane did not receive a fair trial because the colonial administration in Lower canada so thoroughly manipulated the legal system that a guilty verdict was assured. But, ironically, McLane was a guilty man, having been hired by Adet to find sympathizers who would help instigate a rebellion in the colony; he was also employed to gather military intelligence and to help the French seize Lower Canada.

The paper also looks at the attempts of the French between 1793 and 1797 to stir up unrest in the colony and their intentions to spark a rebellion and/or to invade Lower canada. Furthermore, the work discusses the fear that the colony's English community felt due to their perception of the French threat and to their belief that the local Francophone population might rise en masse in an insurrection. Finally, the thesis examines the steps that the English took in response to those fears.

The transcript of the McLane trial was found at the Willamette University College of Law Library and the pre-trial depositions of the prosecution's witnesses were located in the collection of the oregon Historical society. Many of the research materials were obtained from the libraries of Portland State University, Lewis and Clark College, willamette University, oregon state University, the University of oregon, the University of New Brunswick, 
and the University of Western Ontario or were obtained through the interlibrary loan offices at Portland state University and the Salem Public Library. Materials were also obtained directly from Canadian historian F. Murray Greenwood, the editorial office of the Dictionary of Canadian Biography, the National Archives of Canada, the City Archives of Providence, Rhode Island, and Dr. Claire Weidemier McKarns of Encinitas, California. Most of the early Lower Canadian statutes and other information concerning Lower Canadian and British legal history were found at the oregon supreme court Library. Also, most of the biographical information concerning McLane's early years and his family was found at the Genealogical section of the oregon State Library and through the family history centers at the Corvallis (oregon) and the South Salem (oregon) Stakes of the Church of Jesus Christ of Latter-Day saints. 
THE TIMES, TRIAL, AND EXECUTION OF DAVID MCIANE:

THE STORY OF AN AMERICAN SPYING IN CANADA FOR THE FRENCH

IN $1796-1797$

by

MARK ALLEN THORBURN

A thesis submitted in partial fulfillment of the requirements for the degree of

MASTER OF ARTS

in

HISTORY

Portland State University

1993 
TO THE OFFICE OF GRADUATE STUDIES:

The members of the Committee approve the thesis of Mark Allen Thorburn presented November 1,1993 .
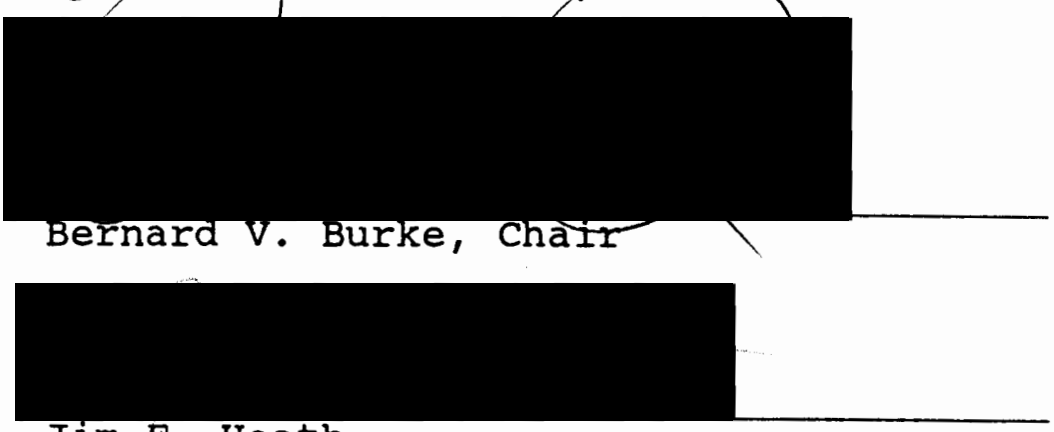

Jim.F. Heath

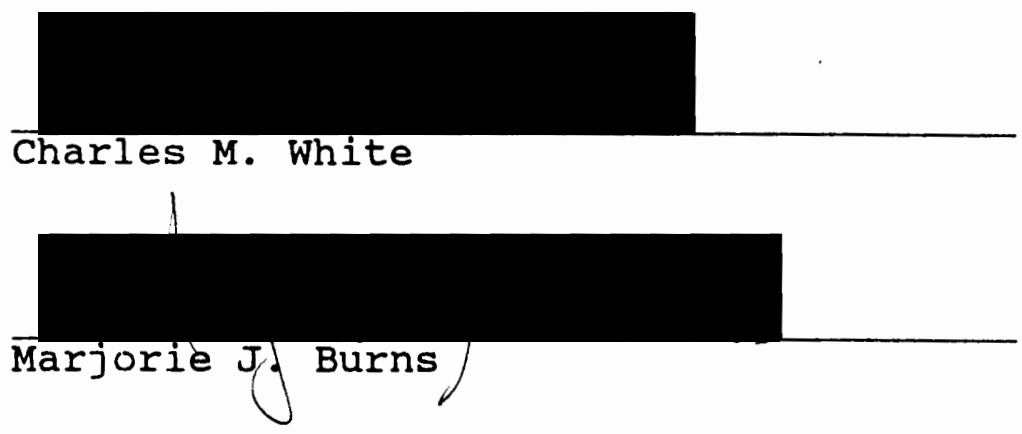

APPROVED:

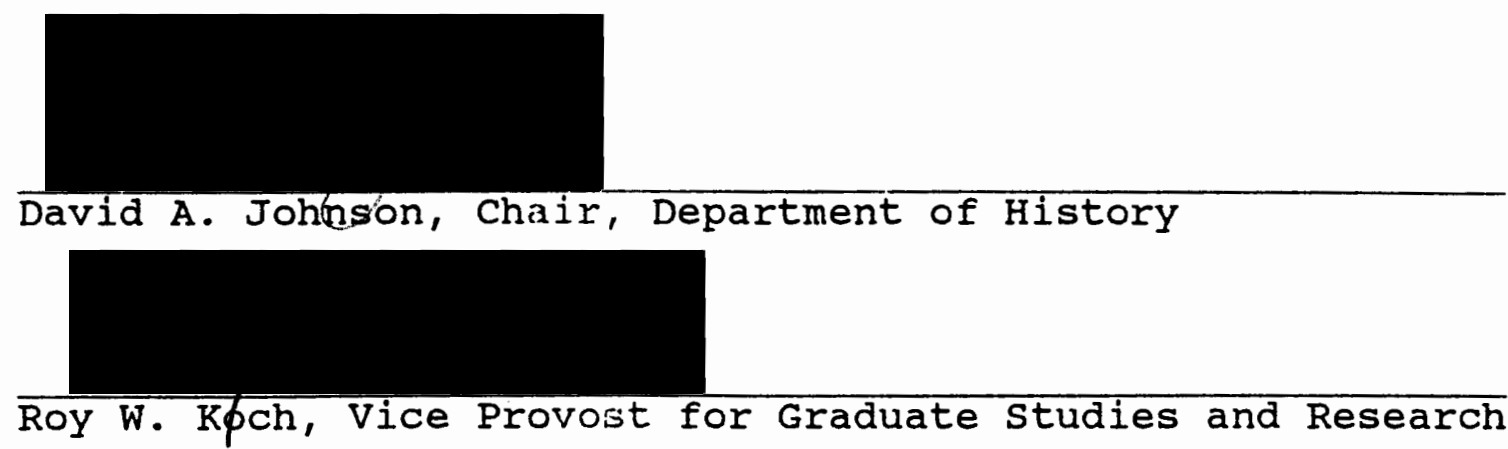




\section{ACKNOWLEDGMENTS}

I would like to thank the members of my thesis committee, Dr. Bernard Burke, Dr. Marjorie Burns, Dr. Jim Heath, and Dr. Charles White, as well as Maureen orr Eldred of Portland State University's Office of Graduate studies, for the time and energy they spent in reviewing my thesis, for the comments and suggestions they offered regarding its final editing, and for their encouragement and recommendation that I continue researching the events surrounding David McLane's life.

I am also grateful to Dr. F. Murray Greenwood for providing me with a copy of the manuscript of his most recent work, Legacies of Fear: Law, Politics and Ideology in Quebec/Lower Canada During the Period of the French Revolution (1784-1811), which was not yet published when I did the research for this thesis, and for helping me find the transcript of the Mclane trial.

In addition, I would like to thank Dr. Claire

Weidemier McKarns for providing important information about her ancestor, Thomas Butterfield, who played a major roie in the McLane affair.

Evelyn Crowell, the Interlibrary Loan Librarian at Portland State University's Branford P. Millar Library and 
her staff, as well as Lee Ellington, secretary for the Department of History at Portland state University, Jane Graham, the Associate Editor of the Dictionary of Canadian Biography, Sylvia Guidry, the Microforms Library Assistant at the University of New Brunswick's Harriet Irving Library, Carole Pace, the city Archivist for Providence, Rhode Island, Miriam Johnson, Interlibrary Loan Director at the Salem Public Library in Salem, oregon, Patricia Kennedy of the state and Military Archives Programme, Manuscript Division, Historical Resources Branch, National Archives of Canada, Johannah Sherrer, the Director of the Aubrey Watzek Library at Lewis and clark College, and Barry Taylor and John Tyndall, assistant librarians with the University of Western Ontario Library system, all have my gratitude for their patient and quick help in response to my many requests for assistance. And, most importantly, I want to thank my loving Companion, Donna McElroy, for her patience and understanding while I was working on this thesis, for her many hours of reading and editing the drafts of this work, for her valuable questions, comments, and suggestions, and for just being there when I needed her. 
TABLE OF CONTENTS

PAGE

ACKNOWLEDGMENTS . . . . . . . . . . . . . $i$ ii

PREFACE . . . . . . . . . . . . . . . . vii

CHAPTER

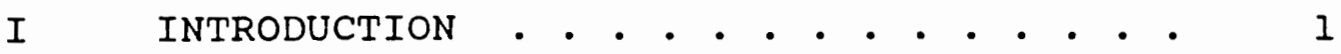

II HISTORY OF CANADA, 1760-1791 . . . . . . 6

III FRENCH INVOLVEMENT IN CANADA, 1791-1796 . 10

Genet and Meziere . . . . . . 10

Fauchet and Thorn ...... 20

The Directory and Ira Allen . . . . 24

Adet and Friends . . . . . . . 29

IV FEARS OF THE ENGLISH COMMUNITY IN CANADA 35

V THE LIFE OF DAVID MCLANE . . . . . . . 47

VI MCLANE'S RECRUITMENT OF FRENCH SYMPATHIZERS

IN CANADA . . . . . . . . . . . 59

VII MCLANE'S INTELIIGENCE GATHERING AND

MILITARY EFFORTS • • • . . . . . 93

VIII MCLANE'S ARREST, ATTEMPTED RESCUE, AND

THE COURT THAT TRIED HIM . . . . 106

IX THE GRAND JURY . . . . . . . . . . . 123

$\mathrm{X}$ THE LAWYERS AND THE INDICTMENT . . . . . 134 
XI THE JURY . . . . . . . . . . . . . . 142

XII TESTIMONY, LEGAL ARGUMENTS, AND SENTENCING 150

XII CONCLUSION • . . . . . . . . . . . . 172

SOURCES CONSULTED • . . . . . . . . . . . . . . 175 
PREFACE

Mclane's name was spelled by his contemporaries and subsequent historians in a variety of ways. He, however, spelled it "McLane" and, occasionally, "M'Lane." Therefore, except when quoting a primary source or when citing a reference, his name shall always be spelled as "McLane" in this paper.

In the 1790's, "Canada" consisted of what became, in 1791, the colonies of Upper Canada (now ontario) and Lower Canada (now Quebec) and it did not include New Brunswick, Nova Scotia, Prince Edward Island, the island of Newfoundland, or the western provinces. Whenever the term is used in this paper, it will be used in the context of that meaning.

Furthermore, in the 1790's, the Francophone population in Canada referred to themselves as "Canadiens" and to the English-speaking colonists as the "English." The Anglicized "Canadian" is used in this paper to refer to the Canadiens and the English-speaking colonists are referred to as the "English" and the "British."

Finally, the transcript of David McLane's trial for treason, as well as a transcript of the arraignment and the 
grand jury proceedings, is included in:

William Vondenvelden, The Trial of

David M'Lane for High Treason at the City of

Quebec, in the Province of Lower-Canada, on

Friday, the Seventh day of July, A.D. 1797:

Taken in Short-hand at the Trial (Quebec:

W. Vondenvelden, Law Printer to the King's Most

Excellent Majesty, 1797)

Vondenvelden was the court reporter at the trial as

well as the royal law printer for the colony. The

transcripts were reprinted in:

William Vondenvelden, "Trial of

DAVID MACLANE for High Treason; before the

Court holden under a Special Commission of oyer and Terminer, at the City of Quebec in the

Province of Lower Canada, on Friday the 7 th day of July: 37 GEORGE III. A.D. 1797," in Vol. 26,

A Complete Collection of State Trials and

proceedings for High Treason and other Crimes

and Misdemeanors from the Earliest Period to

the Year 1783, with Notes and other

Illustrations: Complied by T.B. Howell, Esq.

F.R.S.F.S.A. and Continued from the year 1783

to the Present Time, by Thomas Jones Howell

(London: T.C. Hansard, 1819), 721-828.

In the preparation of this thesis, the latter was

used. Also, for convenience, all footnote citations contained in this work that refer to the transcripts are made in the format suggested by Aniform System of

Citation, 12th Edition (Avon, Massachusetts: Lorell Press, 1976) which is the generally recognized guide in the legal profession as to how to cite legal cases in footnotes. Therefore, the citation in this text to the transcripts is: 
For example, page 800 of the transcripts will be cited as:

26 State Trials $721,800$.

Both sources of the transcripts are cited amongst the "Sources Consulted" on page 175 as according to

Kate L. Turabian's A Manual for Writers of Term Papers,

Theses, and Dissertations Fifth Edition (Chicago and

London: University of Chicago Press, 1987). 
CHAPTER I

INTRODUCTION

On the morning of July 21, 1797, David McLane, an American, was taken from the jail in Quebec City, placed upon a hurdle, and brought to the gallows erected upon the Glacis outside the walls of the local garrison. Escorted by the sheriff, the peace officers of the district, a guard of fifty soldiers, and an immense crowd of spectators, Mclane reached the place of his execution at about 10:15 AM. Once there, while wearing white linen grave clothes and a white cap on his head, Mclane rose up from the cart and engaged in fervent prayer for a few minutes with the attending ministers, the Rev. Mr. Mountain and the Rev. Mr. Sparks. Mclane then informed the executioner that he was ready and, as directed, climbed the ladder that lead to the noose. /1/ He then turned to the crowd and said that:

this place gives me pleasure; I am now going where I have long wished to be, and you, who

126 State Trials 721, 826-828; Quebec Gazette, $27 \mathrm{July}$ 1797; William Renwick Riddell, "Canadian state Trials: The King v. David Mclane," in Royal Society of 
now see me, must all follow me in a short time, some of you perhaps in a few days; let this be a warning to you to prepare for your own deaths. /2/

And then, to the soldiers standing at attention around the gallows, McLane said:

you, with arms in your hands, you are not secure here, even with your arms, I am going where I shall be secure without them. /3/

Mclane then drew the cap over his face while exclaiming "Oh God receive my soul! I long to be with my Jesus" and, while young women screamed out offers of marriage in the vain hope of saving him, he dropped his handkerchief which signaled the executioner to kick away the ladder upon which the prisoner was standing. McLane struggled only briefly, but his body hung for twenty-five

I (continued)

Canada: Transactions, 3rd ser., 10 (May, 1916), sect. II: 327-328; F. Murray Greenwood, "The Treason Trial and Execution of David McLane," in Glimpses of Canadian Iegal History, eds. Dale Gibson and W. Wesley Pue (Winnipeg: Legal Research Institute of the University of Manitoba, 1991), 1; F. Murray Greenwood, Legacies of Fear: Iaw, Politics and Ideology in luebec/Lower Canada During the period of the French Revolution (1784-1811), TMs [photocopy], pg. 304-305n38, Original in possession of F. Murray Greenwood, White Rock, British Columbia, Published: October, 1993 by the Osgoode Society, Toronto.

Remarks of David McLane, July 2I, 1797, spoken to the public witnessing his execution, quoted in 26 state Trials $721,827$. spoken to the military guard present at his execution, quoted in 26 state Trials $721,828$. 
minutes. A platform with a raised block was then brought near the gallows and a fire was made. /4/ After the body was taken down, McLane's head was:

cut off, and the executioner holding it up to public view proclaimed it the "head of a traitor." An incision was made below the breast and a part of the bowels taken out and burnt; the four quarters were marked with a knife, but were not divided from the body. /5/

The entire execution, the first in British

North America for treason, took about two hours. /6/

There is no doubt that David Mclane was a French spy. The account books of Pierre Adet, the French Minister to the United States, record four payments ordered by Adet to "Major Macklay" along with four receipts signed by Mclane. The payments, totaling $\$ 345$, are dated october 13 and 16 , 1796, December 27, 1796, and January 31, 1797. The entry Ibid.

A slightly different, and definitely more gruesome, description of the execution, can be found in [Anonymous], The Trial, Condemnation and Horrid Execution of David M'Lean, Formerly of Pennsylvania, for High Treason Against the British Government, at the city of quebec, on the 2Ist day of July last, who was hanged, drawn, guartered, and beheaded on the above day, with all the attendant circumstances of cruelty and barbarity. (Windham, CT: No publisher listed, 1797), 10-12. State Trials," 321, 328n1; Greenwood, Legacies of Fear, $304 n 38$. 
for December 27th includes Adet's notation that McLane "has been employed by me to obtain intelligence about Canada - he has made a trip into that country" and the entry for January 3 lst states that the payment made on that date was an advance to support a mission entrusted to "major M'Klay." /7/

But even if McLane was innocent, he still would have been convicted and hanged. Britain was currently fighting for her life against France and the English colonists in Canada were horrified at that prospect that, with Austria's recent withdrawal from the alliance against the French, the Directory might invade England itself. Furthermore, McLane's arrest on May 10, 1797, was preceded by four years of spying and plotting by French agents and American conspirators hoping to wrest Canada from British rule and the colonial officials in Lower Canada were aware of these activities. More importantly, McLane's capture came at a time when the government and the British ruling class in Lower Canada not only expected an immediate French invasion, but also intensely feared both the vast canadian majority in the province and the possibility that they would rise en masse in an armed rebellion. These fears

7 Greenwood, Legacies of Fear, 141; L.O.C., France, Archives des Affaires etrangeres, Correspondance politique, Etats-Unis, Supp., Vol. 19, no page numbers cited, in (and presumably translated by) Greenwood, "The Treason Trial," 2n2. 
were greatly exaggerated, but were nevertheless real, and the colonial government was determined to make an example of Mclane to deter potential traitors and spies. Thus, while McLane received a technically fair trial, the government, the prosecutors, and the court manipulated the law to guarantee a guilty verdict and McLane's death. 
CHAPTER II

HISTORY OF CANADA, 1760-1791

To understand the fears of the English in Lower Canada in the 1790's, a brief examination of the colony's history is required. In 1760 , during the middle of the Seven Years War, the French city of Quebec fell and Canada was surrendered to the British. Three years later, France formally ceded the colony (except for the small islands of Miquelon and st. Pierre) to England and the British continued to govern Canada by military rule until 1774. In the latter year, the English Parliament adopted the Quebec Act which changed the colony's name to "Quebec," restored civilian control, and permitted the canadians to participate in the local government. These and other elements of the Quebec Act were looked upon with disfavor by the English colonists on the Atlantic coast and were among the reasons behind the bitterist military conflict to-date in North America, the American Revolution. After Great Britain acknowledged the political independence of the United states, it asked for leniency for those colonists in "the states" who remained loyal to the crown during the war, but these loyalists were harshly treated, their property often confiscated, and they were frequently 
declared enemies of the new nation. As a result of this and the desire to live under British rule, 20,000 loyalists emigrated from the United States to Nova Scotia and New Brunswick and another 10,000 to western Quebec in the 1780's. But in addition to the treatment of the loyalists, distrust and even hatred of the Americans were engendered for decades to come by the ferocity of the Revolution, the United States' occupation of Montreal and the battle for Quebec city during the war, and by the frequent calls in America for an attack on Canada and for seizure of the st. Lawrence River as a waterway. /8/

The influx of the loyalists into Quebec brought to a head a conflict between the canadians and the British that had existed since the adoption of the Quebec Act. Under the Act, the civil law that was enforced in canada and, therefore, the law which determined real property rights, was French. However, under that legal system, settlers

8 F. Frith Jeffers, History of Canada, History primers, New and Enlarged Edition (Toronto: Canada Publishing Company, 1894), 37-42; Eugene Perry Link, Democratic-Republican Societies, 1790-1800, Columbia studies in American Culture Series (New York: Octagon Books, 1973), 141; Patricia Kennedy, state and Military Archives Programme, Manuscript Division, Historical Resources Branch, National Archives of Canada, ottawa, Ontario, August 11, 1993, Unrecorded telephone interview by Mark Thorburn. 
held their land by seigniorial tenure, which was both foreign to and unpopular with the English. /9/ And there were other long-standing frictions between the English settlers and the canadians, including nationalism, ethnic and religious hostility, cultural diversity, the possession of political and financial power, patronage, and the dreams of empire-building. /10/

In order to separate the two communities, Quebec was divided in 1791 into two colonies: Upper canada (now ontario) with 20,000 inhabitants, almost entirely British,

9 Jeffers, History of Canada, 43-45.

Established by the French to encourage the colonization of North America, seigniorial tenure meant that Canada was divided into portions of varying sizes that were given to those in the king's favor. These land-owners, called "seigneurs," would, in turn, divide their property (the "seigneuries") among settlers who lived upon the land for as long as they paid to the seigneurs, who still owned the property, an amount based upon the value of the land, the structures built upon it, and the income derived from it. In contrast, under English law, a person desiring to own a piece of land would pay for it just once, would receive a deed from either the government or the previous owner, would own the land free and clear of anyone else's claims of ownership, and, except for taxes, would be free from all future payments on the land. Jeffers, History of Canada, 45.

10 For a detailed anaylsis of the differences between the Canadians and the English colonists between 1759 and 1837 and of the historiography of the conflict, see F. Murray Greenwood, "The Development of a Garrison Mentality Among the English in Lower Canada, 1793-1811" (Ph.D. diss., University of British Columbia, 1970), I-22. 
and Lower Canada (now Quebec) with 130,000 residents of which the vast majority were canadians. /11/ However, despite their minority status, the English lawyers and merchants, as well as the seigneurs, remained the governing class in Lower Canada, but they were scared to death that their rule might crumble; the colony's defenses were inadequate against either an external or internal threat and when the French Revolution turned violent in 1791 and France and Britain went to war the following year, the English became convinced that the Canadians, most of whom were farmers with guns living along the two expected invasion routes, would rise up in support of a French invasion force which might appear at any time. And to top it all off was the knowledge and fear, and a belief in the efficacy, of French spies. /12/

11 One historian, Michel Tetu, states that, in 1794, 25,000 English and 150,000 Canadians lived in Lower Canada, thus giving the British approximately $14 \%$ of the colony's population. However, F. Murray Greenwood estimates that, at the time of McLane's trial, the English were outnumbered by the Canadians by fifteen to one, which would make the British community in Lower Canada equal to only six percent of the population. Sir Robert Prescott, the governor of Lower Canada in 1797, believed that the proportion of British colonists to Canadians was even lower; 70 to 2000 or little more than three percent of the province's population. Michel Tetu, "Quebec and the French Revolution," Canadian Parliamentary Review, 12:3 (Autumn, 1989): 4; Greenwood, "The Treason Trial," 3 . Greenwood, "Garrison Mentality," 23-24; Greenwood, "The Treason Trial," 2-3. 
CHAPTER III

FRENCH INVOLVEMENT IN CANADA, 1791-1796

GENET AND MEZIERE

To a certain extent, the fear of French agents roaming Lower Canada was justified. After the cession of canada in 1763, the prevailing attitude in the old Regime was that Britain's retention of Canada was to France's advantage; first, it encouraged the British colonies in North America to revolt and, after the United states won its political independence, a Canada under British rule was a useful counterweight to the growing power of the new republic (which France hoped would be a weak and dependent satellite state). Later, during the first few years of the French Revolution, there was little interest in France regarding canada. /13/ But by late 1792, Paris

13 R. Flenley, "The French Revolution and French Canada," chap. in Essays in Canadian History Presented to George Mackinnon Wrong for His Eightieth Birthday (Toronto: Macmilian Company of Canada, Ltd, 1939), 47-48, 53; Mason Wade, "Quebec and the French Revolution of 1789: The Missions of Henri Meziere," Canadian Historical Review 16:4 (December, 1950), 345; Thomas G. Paterson, J. Garry Clifford, and Kenneth J. Hagan, American Foreign Policy: A History to 1914, 3d ed. (Lexington, MA: D.C. Heath and Company, 1988), 16, 29. 
anticipated going to war with Britain and Spain and was prepared to make the United States as strong as possible in order to weaken both powers' strength in the Americas. Therefore, when Edmond Genet became the French Minister to the United States that December, he was instructed to spread the principles of liberty and independence to the territories bordering the United States, including Canada, as well as to seek a Franco-American alliance that would perhaps lead "to reuniting the beautiful star of Canada to the American Constellation." Genet was also to convince the Americans that, in the event of an Anglo-French conflict, it was in the United States' interest to seize Canada and Nova Scotia and, if necessary, he was to tell Congress that France would support such an expedition with a formidable fleet and troops. /14/

14 Flenley, "The French Revolution and French Canada," 56; Wade, "Quebec and the French Revolution," 345-346; Meade Minnigerode, Jefferson. Friend of France, 1793: The Career of Edmond Charles Genet, Minister Plenipotentiary from the French Republic to the United States, as Revealed by His Private Papers, 1763-1834 (New York: G.P. Putnam's Sons, 1928), 142, 143-144; "Memoire Pour Servir d'Instruction au Citoyen Genet Adjudant-General-Colonel, Allant en Amerique en Qualite de Ministre Plenipotentiare de la Republique Francaise Pres le Congres des Etats Unis," 2 xbre 1792, in F.J. Turner, ed., Correspondance of French Ministers, 1791-1797, Vol. 2, Annual Report of the American Historical Association for the Year 1903 (Washington, Government Printing office, 1904), 203-204, quoted in (and presumably translated by) Wade, "Quebec and the French Revolution," 346. 
Once in the United States, Genet wrote to the to the French consuls in New York and Boston and told them that it was urgent to introduce "the ferment of independence." /15/ Genet soon decided that one of the best ways to accomplish these goals was through "addresses and printed matter of a sort suited to make spring up in their hearts the sacred faith of liberty" that would be printed in Boston and distributed through channels to be found by the local French consul. Finally, to assist the consul in Boston with these tasks, Genet hired a twenty year old Canadian, Henri Meziere. /16/

Born in Montreal to a prominent lawyer, Meziere studied at the College de Montreal where he read the works of Rousseau and had devoted himself to spreading the gospel of the rights of man throughout canada. Deciding that the colonial government would soon be after him, Meziere fled

15 Wade, "Quebec and the French Revolution," 347-348; Genet a Dannery, 7 juin 1793, and Genet a Hauterive, 4 juin 1793, L.0.C., Genet Papers (17931801), both quoted in (and presumably translated by) Wade, "Quebec and the French Revolution," 347-348.

16 Genet a Dannery, 7 juin 1793, L.O.C., Genet Papers (1793-1801), quoted in (and presumably translated by) Wade, "Quebec and the French Revolution," 347-348. 
to the United States in early 1793 and met Genet in Philadelphia that May, hoping to obtain employment and passage to France. /17/

Genet first had Meziere prepare a memorandum regarding the military situation in Canada. The report, which was submitted on June 12th, described the British military in the region and claimed that the Canadians would have no reluctance to shake off British rule. Meziere further indicated that the best way to begin stirring up a revolution was to circulate an address amongst the Canadians, but that it should not be done until French troops were on the borders of Canada lest the patriotic fever prematurely die. /18/

17 Wade, "Quebec and the French Revolution," 348-349; Flenley, "The French Revolution and French Canada," 54 .

Wade, "Quebec and the French Revolution," 349-351. 
Based upon these recommendations, Genet wrote an eight page pamphlet entitled the Les Francais libres a leurs

freres les canadiens that urged the Canadians to:

Imitate the example of the peoples of America and France. Break with a government which degenerates daily, and which has become the bitterest enemy of popular freedom.

Canadians! arm yourselves, call to your aid your allies the Indians, count upon the support of your neighbors, and on that of France. /19/

Genet then instructed Meziere to:

go to the frontiers of Canada, establish Correspondence with Canadians whose sentiments correspond to his, and convey to them the address . . . in which I have developed the political views of the Republic with regard to the canadians. /20/

19 Edmond Charles Edouard Genet, "Les Francais libres a leurs freres les Canadiens," juin 1793, Canadian Archives, Q. 69 (2), 224-226, quoted in (and presumably translated by) Flenley, "The French Revolution and French Canada," 56-57.

A slightly different translation is found at Mason Wade, The French Canadians, 1760-1967 (Toronto: Macmillan of Canada, 1968), 98.

An extract, in French, is found in william Kingsford, The History of Canada (Toronto: Rowsell and Hutchinson, 1894), Vol. 7, 387n.

Edmond Charles Edouard Genet, "Instructions pour le Cit. Meziere, agent de la Republique francaise aupres des Canadiens," 1793, L.0.C., France, Archives des Affaires etrangeres, Correspondance politique, Etats-Unis, Supp., vol. 28, pt. 2, 382-382v, in (and presumably translated by) Wade, "Quebec and the French Revolution," 354 . 
That July, Meziere went to Cumberland Head on Lake Champlain and hired Jacques Rous, a Canadian who had emigrated to the United States in 1777 , to serve as his agent and courier in canada. It is possible that, at this time, Rous was a double agent; it is known that he later worked for John Richardson, head of the British secret service in Montreal. Meziere provided Rous with personal letters to "people in Montreal, whom I believe to be the most discreet and best disposed" as well as 350 copies of Genet's pamphlet and other materials to be distributed amongst the population. /21/ Two months later, after

21 Wade, "Quebec and the French Revolution," 354-355; Meziere a Genet, 20 septembre 1793, I.O.C., France, Archives des Affaires etrangeres, Correspondance politique, Etats-Unis, vol. 38, pt. 3, 235-238v, in (and presumably translated by) Wade, "Quebec and the French Revolution," 355. 
going to Montreal, Rous reported that the British knew of Meziere's presence and had ordered Meziere's arrest. /22/ Rous also reported that all of the materials given to him, except for Genet's address, had been distributed in Montreal; the pamphlets were kept because "with a people wholly plunged in the dense shadows of ignorance and

Indeed, the British did know of Meziere's presence. On september 9, 1793, Lieutenant J.H. Schoedde, the Commanding officer of the 6oth Regiment at Fort Ontario wrote:

By very late advice from New York,

I am informed that a Mr. Mezieres [sic]

(for some time secretary to Genet) is now on his way to Canada, as it is said with a view of fomenting divisions amongst the Canadians. Schoedde to Le Maistre, September 9, 1793, Canadian Archives, Series 2 , Vol. 673,21 , in Douglas Brymner, "French Republican Designs on Canada," chap. in Report on Canadian Archives (Ottawa: S.E. Dawson, 1892), Note $D, 57$.

And two weeks later, the colonial governor in Upper Canada was writing:

I have just received Information by a Person of credibility, that a French Man by the name of Mazeres or Meziere, has been sent by Mons. Genest [sic] the French Resident in the United States, into Lower Canada. Simcoe to Clarke, september 24,1793 , Canadian Archives, series $C$, Vol. 673 , 20, in Brymner, "French Republican Designs on Canada," Note D, 57. 
slavery, it is not fitting to suddenly cause to shine the sun of Iiberty at noon." /23/ Rous further said that the public opinion in Montreal was "forever fixed in favour of the French" and that "nothing is so common, even in the country, as the cry of Vivent les Francois!" Furthermore, Rous indicated that "nothing [would be] so easy as to attack them [the British military forces] at the mouth of the st. Lawrence" and that "the French flag would only have to show itself to free Canada." /24/ Based on this, Meziere recommended to Genet an immediate naval expedition against Quebec, the distribution of more pamphlets and addresses in Canada, and his own return to the border with a plan to be followed by the Canadians when the French navy arrived. /25/

Wade, "Quebec and the French Revolution," 355-357: Meziere a Genet, 20 septembre 1793, L.O.C., France, Archives des Affaires etrangeres, Correspondance politique, Etats-Unis, vol. 38, pt. 3, 235-238v, in (and presumably translated by) wade, "Quebec and the French Revolution," 356.

24 Wade, "Quebec and the French Revolution," 357; Meziere a Genet, 20 septembre 1793, I.O.C., France, Archives des Affaires etrangeres, Correspondance politique, Etats-Unis, vol. 38, pt. 3, 235-238v, in (and presumably translated by) Wade, "Quebec and the French Revolution," 356-357. 
Ironically, just after Meziere had left for the Canadian border in July, a mutinous French fleet from San Domingo arrived in the United States. Genet quickly decided to use the vessels to destroy the Newfoundland fisheries, retake St. Pierre and Miquelon, attack Halifax, and recover any French prisoners who were held there by the British. /26/ Then, on its way back to New York, the fleet would:

sound the dispositions of our former brothers the French of Acadia, make descents on their coasts, not to pillage them, but to spread among them our principles, our Constitution of June 24, 1793, our patriotic songs, the Bulletin, and [the] revolutionary addresses that I have drawn up for the Canadians. /27/

27 L.O.C., France, Archives des Affaires etrangeres, Correspondance politique, Etats-Unis, vol. 39 , pt. 2, 110, in (and presumably translated by) Wade, "Quebec and the French Revolution," 359. 
In all, the attack fleet consisted of two ships of the line, five field-pieces, troops, and arms. /28/ The ships sailed on October lith and, among their passengers, was Meziere who had been attached by Genet to the fleet as a political agent. Meziere, however, never got to Canada; once at sea, a naval council of war decided that it was impossible to fulfill the essential part of Genet's plan without undue risk and that it was better to sail for France. On November 2nd, Meziere found himself at Brest. /29/

Historian Mason wade indicates that 300 troops, all volunteers who came to America with the San Domingo fleet, along with a company of dragoons, the origin of which he does not explain, sailed with the squadron for Canada. F. Murray Greenwood, however, states that Genet recruited 2500 men, mostly American adventurers and Irish and French residents of New York City, to sail with the fleet, but does not indicate how many actually went. And Lord Dorchester, the Governor of Lower Canada in 1794, had it on good information that the fleet included 2500 troops as well as two ships of the line, two large frigates, a sloop of war, and two armed brigs. Wade, "Quebec and the French Revolution," 359; Greenwood, "Garrison Mentality," 26; Brymner to Carling, December 31, 1891, in Brymner, "Introduction," chap. in Report on Canadian Archives, xxxix.

Wade, "Quebec and the French Revolution," 359-361, 362-363; Greenwood, "Garrison Mentality," 26-27; Flenley, "The French Revolution and French Canada," 57.

Even if the fleet had obeyed Genet's orders, the British would have been waiting for them. An English spy was in the San Domingo squadron and, as a result, the British authorities in Halifax knew the fleet's plans in detail and had assembled 4000 men for 
FAUCHET AND THORN

The French Revolution and the war between France and Great Britain proved to have a divisive effect upon the United states. Initially, the French political and social upheaval met with near unanimous approval in America, but King Louis' execution and the Reign of Terror that followed repulsed the conservative followers of the Federalist Party. In contrast, the Democratic-Republicans applauded the events in France and began organizing societies similar to the French Jacobian clubs. Furthermore, the Federalists favored Anglo-American trade and cooperation while the Republicans wanted to reduce the United States' economic ties to the British. President Washington proclaimed the United states' neutrality in the Anglo-French war on April 22, 1793. However, Genet took several steps while in the United States that brought Franco-American relations close to a breaking point. Not only did Genet attempt to stage a rebellion and an invasion of Lower Canada from the United states, but he also commissioned fourteen privately

29 (continued)

defense long before the ships sailed. Wade, "Quebec and the French Revolution," 361; Brymner to Carling, December 31, 1891, in Brymner, "Introduction," xxxix. 
owned American ships as French privateers to raid British commerce. He also planned the capture of Spanish-held Louisiana with an expedition consisting primarily of American volunteers, encouraged pro-French editorials in the American press, and even appealed once directly to the American people over Washington's head. Eventually, Genet was deemed so objectionable that washington asked Paris to order its diplomat home. On october 11, 1793, the same day that Genet's invasion fleet sailed, the French government decided to recall the envoy. He was replaced by Jean Fauchet who, once in the United States, reflected upon the growing coolness of Franco-American relations. Based on his observations, Fauchet recommended that France do two things; first, focus on Louisiana as the center of French influence in North America and, second, keep the United states uneasy by leaving Canada in British hands. /30/ But Fauchet apparently reconsidered his position regarding Canada towards the end of his tenure as Minister when Stephen Thorn wrote to him in November, 1794 .

Thorn, a young man from Granville, New York, was an ardent supporter of liberty who became thoroughly disgusted when the United States government failed to fully support

30 Paterson, American Foreign Policy, 42-46; Wade, "Quebec and the French Revolution," 362 ; Flenley, "The French Revolution and French Canada," 57 . 
Genet and the revolutionary cause in France. Sometime in 1794, on his own initiative, Thorn traveled across Lower Canada making discreet inquiries about the attitudes of the canadians. Thorn discovered that they were aware of what was going on in Europe, including the fact that the French armies had driven their enemies out of France and had launched successful counteroffensives. He also received the impression that the British officials in Canada were trying to suppress the news of the French victories and that the canadians were groaning under British oppression and longing for freedom. Thorn concluded that the only reason the Canadians did not rebel was because they lacked the necessary arms and that, given the means, they would overthrow the colonial government. Thorn then developed, by the autumn of that year, an association of English-speaking radicals residing in Upper and Lower Canada and the northern parts of the United states who were interested in promoting revolution in Canada. /31/

That November, Thorn went to Philadelphia and shared his impressions of Canada and the canadians with Fauchet, suggesting that the French might want to help their former

31 T.S. Webster, "A New Yorker in the Era of the French Revolution: Stephen Thorn, Conspirator for a Canadian Revolution," The New York Historical Society Quarterly 53:3 (1969): $251-253$. 
colonists regain their freedom and assist canada in becoming a department of France. Within a few weeks, Thorn was on his way to France, probably with letters of introduction to various influential Frenchmen. During the summer of 1795, Thorn met several times with the French spy, Robert Pelleve, and, on August 7th, submitted to the Committee of Public Safety a plan for the seizure of Canada. /32/ According to Thorn, many of the people who would participate in the operation were Americans who had settled in Canada after the Revolution and he even suggested two residents of Vermont, as well as himself, as officers in the expedition, one of whom was Ebenezer Allen, the older brother of Ira Allen. /33/

On August 14th, Pelleve reported to his superior, General Laurent Jean Francois Truguet that if the Committee of Public Safety was to approve Thorn's plan, then it would have to be carried out with great speed and secrecy. Later that month, with the knowledge of the French government, Pelleve sent Thorn to Britain as a spy. Thorn returned to Paris by the following February, but in the meantime, a new Ibid., 253-254, 256-257.

33 Ibid., 255; David Maunsell, Lawton V. Crocker, and Dorman B.E. Kent, Gazetteer of Vermont Heritage, (Chester, VT: The National Survey, 1966), 24-26. 
constitution for France had been adopted, the National Convention had dissolved, and the Directory had come to power. On February 27, 1796, Thorn resubmitted his proposals to Truguet, who was now the French Minister of Marine and Colonies. However, Thorn never received a response from Truguet or the Directory, although he did later play a role in the plots of Ira Allen. /34/

\section{THE DIRECTORY AND IRA ALLEN}

Best known as the founder of Vermont, Ira Allen was not, unlike Meziere and Thorn, working for any noble cause when he planned to incite rebellion in Canada; instead, his motive was entirely pecuniary. The Allen family had strong economic ties with Lower Canada, but by 1795, Ira was in serious financial difficulties and a canal between Lake Champlain and the st. Lawrence through the rapids of the Richelieu River, as well as the right of navigation on the st. Lawrence, were essential to his prosperity. In late 1795, Allen left for London with fellow Vermonter John Graham to convince the British of the need for a canal, but intending to incite a rebellion in Lower Canada to get his way should Britain fail him. To finance his Revolution," 255-256, 257-261, 260n14. 
trip, Allen secured bills of credit from General William Hull (of War of 1812 fame) and it was Hull who suggested that the arms that Allen sought could be purchased cheaply from the French who had no ammunition for the foreign-made muskets and cannons that they had captured. /35/

Allen arrived in London on January 2, 1796 and met soon thereafter with the Home Secretary, the Duke of Portland. Allen's plan for a canal, however, was eventually rejected by the British who viewed it as an avenue for invasion rather than as a stimulus for Lower Canada's economy. Allen then left for Paris on May 20th. That June and July, Allen negotiated with members of the Directory (primarily General Lazare carnot) to instigate a rebellion amongst the canadians. /36/

35 Ibid., 260; Jeanne A. Ojala, "Ira Allen and the French Directory, 1796: Plans for the Creation of the Republic of United Columbia," William and Mary Quarterly $36: 3$ (July 1979): 436-438; Chilton Williamson, Vermont in Quandary: 1763-1825 (Montpelier: Vermont Historical Society, 1949), 224-226.

36 Webster, "A New Yorker in the Era of the French Revolution," 260; Ojala, "Ira Allen and the French Directory," 438; Williamson, Vermont in Quandary, 229. 
Allen's goal was the creation in Lower Canada of a republic that would be closely tied to France and, he hoped, the United States. /37/ According to the records of the Directory, Allen indicated that:

Canada is inclined toward revolution, and if the people can count on the support of France they will soon turn their efforts towards independence. But French aid from the commencement of the revolution and assurance of French support are necessary to give proper boldness to the friends of liberty. /38/

In return, France would have "the honor and satisfaction of bringing liberty to the unfortunate French oppressed by kings and priests," its relations with the United states would improve, and its foreign trade would greatly expand. Allen also predicted that if the war

37 Ojala, "Ira Allen and the French Directory," 436. ojala points out that while Allen had originally indicated that the proposed revolution in Canada was to create a republic or to join the colonies to the United states, he later repudiated the idea. ojala, "Ira Allen and the French Directory," 438-439, 441. no author given), messidor an 4, Archives Nationales, Series AF III, Carton $186 \mathrm{~b}$, in (and translated by) ojala, "Ira Allen and the French Directory," 442-448. 
between France and Britain continued, then the loss of Canada and an increase in the British national debt would lead to a revolution in Britain within three years and leave France and the new Canadian republic as the "masters of the seas." /39/ on July 11th, French government agreed to sell to Allen 20,000 foreign-made guns (with bayonets) and twenty-five pieces of artillery and to loan to him a sum equal to forty percent of the purchase price. It was also agreed that Allen would take the arms to Vermont from where, in the spring or summer of 1797 , he would lead an expedition into the st. Lawrence Valley while a French fleet simultaneously entered the st. Lawrence. And finally, before the invasion, the canadians would be prepared to receive their liberators by a group of secret agents operating under the direction of the French Minister to the United states. /40/

[Ira Allen], "Propositions to accomplish a revolution in the English colonies of North America and to create a republic under the name of Reunited Columbia (or to join them to the United states of America) and an indication of some advantages which would result for the French Republic," Document 4 , n.d. Archives Nationales, Series AF III, Carton 186b, in ojala, "Ira Allen and the French Directory," 438-439.

40 Ojala, "Ira Allen and the French Directory," 439-440; Webster, "A New Yorker in the Era of the 
On November 5, 1796, Stephen Thorn, now in Ostend, Holland, chartered the olive Branch to take Allen and the weapons and munitions to New York; on November 12th, the ship sailed with its passenger and cargo. However, Graham, who was still in London, betrayed Allen to the English and, after eight days at sea, the olive Branch came across a British naval vessel who forced it to put about and sail for Plymouth, England. Allen was then imprisoned and the arms were declared to be contraband and were seized. /41/

40 (continued)

French Revolution," 260-261; Williamson, Vermont in Quandary, 229-230: Flenley, "The French Revolution and French Canada," 62.

Webster writes that Allen and the Directory had agreed upon Allen leading an expedition into the st. Lawrence Valley while a French fleet would simultaneously enter the st. Lawrence River, but Williamson indicates a very different invasion plan; i.e., a French army was to land at Halifax, Nova Scotia, while Allen and his militia were to seize st. John, New Brunswick, and then the armies would converge upon Quebec City. Webster, "A New Yorker in the Era of the French Revolution," 260-261; Williamson, Vermont in Quandary, 229. Webster, "A New Yorker in the Era of the French Revolution," 261; Williamson, Vermont in Quandary, 230-240; James Benjamin Wilbur, Ira Allen, Founder of Vermont: 1751-1814, 2 vols. (Boston and New York: Houghton Mifflin Company, 1928), 2:99, 2:110, $2: 230-232$. 


\section{ADET AND FRIENDS}

The United States ratified Jay's Treaty on June 24, 1795. That instrument violated the spirit, if not the letter, of America's 1778 Treaty of Amity and Commerce with France by stipulating that French property and, in certain situations, foodstuffs heading for France that were found on American merchant ships could be seized as contraband whenever the vessels were stopped by the British Navy. News of the agreement was received with indignation by the French government and caused France to view the Americans as allies of the British. Franco-American relations suddenly worsened and the French conquest of canada was now seen by Paris as a way to dictate American foreign policy. 142/ As described by Robert Liston, the British Minister to the United states:

From the time that the Government of America discovered a resolution to maintain her neutrality during the present war, and to enter into relations of commerce and friendship with Great Britain, the French agents in this country [the United states] appear to have suggested to their employers the necessity of

42 Paterson, American Foreign Policy, 47, 50-51; Brymner to Carling, December 31, 1891, in Brymner,

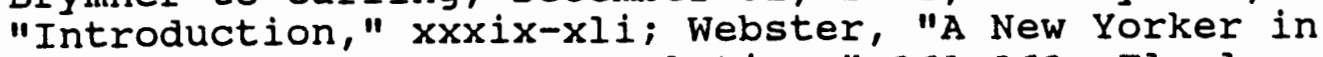
the Era of the French Revolution," 261-262; Flenley, "The French Revolution and French Canada," 60-61. 
obtaining a predominant influence over the United states by means of threats and complusion and the late and the present Minister seem to have agreed in opinion that the only certain means of obtaining this important object was the acquisition of at least a part of the territories formerly possessed by France on the American Continent. Fauchet (as appears from his intercepted correspondance) would have contented himself with the recovery of Louisiana. There is reason to think that Adet, on the contrary, has recommended that this should be joined with the repossession of Canada. /43/

Indeed, Fauchet's successor, Pierre Adet, personally believed that Canada was an indispensable appendage to the French Republic and once wrote that "the spirit of France still lingers, and the name of England is detested" in Canada and, during the summer of 1796, the French Directory accepted Adet's recommendation. /44/

Like Genet, one of Adet's ways to achieve this goal was to draft, and have emissaries distribute, a pamphlet among the Canadians; by October, 1796, enough copies of

43 Iiston to Prescott, November 28, 1796, Canadian Archives, Series Q, Vol. 78, 208, in Brymner, "French Republican Designs on Canada," Note D, 62-63.

Kingsford, The History of Canada, 441-442; Adet aux representans du Peuple Membres du comite de salut public, 8 Thermidor an 3, in Turner, correspondance of French Ministers, 234, quoted in (and presumably translated by) Flenley, "The French Revolution and French Canada," 61; Greenwood, "Garrison Mentality," 32 . 
Adet's address had circulated in Lower Canada that it had come to the attention of the colonial Attorney General, Jonathan sewell. As sewell reported to the colony's Executive Council:

a Pamphlet of a most seditious tendency signed by Adet the Ambassador from the French Republic to the United States was now in circulation in the District, that this Pamphlet bore the Arms of the French Republic and was addressed to the Canadians, assuring them that France having now conquered Spain, Austria and Italy had determined to subdue Great Britain, and meant to begin with her colonies. That she [France] thought it her duty in the first instance to turn her attention to the canadians to relieve them from the slavery under which they groaned and was taking steps for that purpose. That it pointed out the supposed advantages which the Republican form of Government possessed over the British and concluded that in a short time there would be heard only the cry of Vive La Republique from Canada to Paris. /45/

Furthermore, Adet's agents in Canada were telling the Canadians that a French fleet would ascend the st. Lawrence and land at Kamouraslea with 6000 men and 30,000 stand of arms and, once the canadians rose up, Quebec city would immediately capitulate. /46/ Boasting or not, it is known that, in 1796, Adet sent General Georges Henri Victor Collot into Upper Canada to entice the Indians to make a diversionary attack when French troops landed in the east.

45 Report by Attorney General to the Executive Council and Proceedings Thereon, October 30, 1796, Canadian Archives, Series Q, Vol. 78, 96, in Brymner, "French Republican Designs on Canada," Note D, 58-60. 
The response that collot received was positive enough that he recommended going ahead with the plans. /47/ In october of that same year, william stanton, a detective employed by the British to search for Adet's agents, came across five Frenchmen, including Auguste Demilliere, an officer in the French Army, at Rouse's Point at the northeast tip of New York (just a few miles from where, as we shall later see, David McLane was trying to recruit various individuals to join his plot for revolution). The five were originally part of a group of nine who arrived in the area on september 12 th to slip into Lower Canada and distribute blank commissions for the French army and addresses inciting the Canadians to revolt, but their guide had led them astray and they never got to Montreal. (As we shall also see, David Mclane was in Montreal at this very same time.) By mid-october, eight of the spies had dispersed, leaving behind only Demilliere who openly spoke of becoming a general and of Canada being invaded in the spring and had built a small house a half mile south of the border to be used in case the need for a base of operations arose. Before the others left, however, they retained two Canadians, Joseph du Calvette and French Canada," 61. 
Jean Baptiste Louisneau, to complete their task.

Du Calvette and Louisneau were appointed lieutenants in the "Armee Francaise d'outre Mer" and instructed to sound out the Canadians and to "excite and cherish as far as possible a spirit of discontent and opposition to the Government." The two met with some dissatisfied Canadians in Montreal on September 25th and 26th, just before the Road Act riots began; the riots are discussed later. Du Calvette also attempted to distribute some pamphlets that were entrusted to him, but by the end of september he fled to the United states and neither trickery nor a request for his extradition by the British were able to bring him back into Canada; in contrast, Louisneau was arrested, but turned state's evidence and was not charged. /48/

Stanton to Barnes, November 18, 1796, Canadian Archives, Series $Q$, Vol. 78, 145, Report of Attorney General Sewell, May 12, 1797, Canadian Archives, Series Q, Vol. 79-I, 30, and Deposition of Gabriel Sistare, December 1, 1796, Canadian Archives, Series Q, Vol. 78, 153, all in Brymner, "French Republican Designs on Canada," Note D, 60-61, 73-74, and 65-66, respectively; Greenwood, "Garrison Mentality," 38-40, 40n40; Robert Christie, A History of the late Province of Lower canada, Parliamentary and Political, From the commencement to the close of Its Existence as a separate Province, Vol. I (Montreal: Richard Worthington, 1866), 172 ; Pierre Braud, "DeMilliere: Vendee et Canada," February 2, 1991, Working Notes in Possession of the state and Military Archives Programme, Manuscript Division, Historical Resources Branch, National Archives of Canada, Ottawa. 
Also in October of that year, Adet was rumored to have personally made a tour of the U.S.-Canadian border and, on November 28 th, Liston reported to Prescott that a Frenchman named "Arrison" had "lately returned from a tour of several months through canada" and that "he met with considerable success in perverting the minds of the People." /49/ And in November, another agent of Adet, named Aubins, spent some time near Chambly and, in December, the British believed that a French naval officer had entered Lower Canada and was heading for Quebec City. /50/ only after the seizure of Ira Allen and the olive Branch did the French government give up the idea of invading Lower Canada, but the Directory failed to communicate that decision to Adet who continued to assume that a French fleet would attack the colony sometime in 1797 . /51/

Prescott to Portland, October 24, 1796, Canadian Archives, Series $Q, \mathrm{Vol} .78,7$, and Liston to Prescott, November 28, 1796, Canadian Archives, Series Q, Vol. 78, 208, both in Brymner, "French Republican Designs on Canada," Note D, 57-58 and 62-63, respectively.

$$
\text { Ibid., 35, 36n27, 44-45. }
$$


FEARS OF THE ENGLISH COMMUNITY IN CANADA

The English knew about many of the French spies, although, as we have seen, their fears about the effectiveness and efficiency of these agents were exaggerated. Furthermore, the belief, widely held by the British of Lower Canada, that France would attempt to reconquer its former colony was strengthened by these intrigues as well as by the knowledge of Genet's military plans, the correct assumption that the French government had supplied arms to Ira Allen, and the understanding that the Directory's plans to dictate American foreign policy involved the seizure of canada. In addition, the number of English troops in Canada was considered inadequate for the defense of the province and it was realized that British sea power was not a guarantee against a French invasion; indeed, in August, 1796, a French squadron broke through the blockade at Brest and arrived on Newfoundland's shores the next month, destroying a few houses and stores, before returning home. As a result, between 1793 and 1801, both the colonial government and the English residents of Lower Canada considered an invasion by French troops to be a very real possibility and neither the knowledge that 
Genet's san Domingo fleet had sailed for Brest nor of the capture of Allen and the olive Branch did much to reduce their fears. /52/

And, on top of everything, the colony's British population was afraid of a Canadian revolt. After the French Revolution turned violent in 1792, the Canadian elite and middle class turned against the Revolution and the Canadian upper class played a large role in the Lower Canadian loyalty movement of the 1790's. But the Canadian farming class, which was Catholic and predominantly illiterate and poor, constituted the vast majority of the colony's population and they disliked the British and their Protestant, urban-centered, wealthy, educated, and English-speaking ways. The Canadian farmers also detested both the British and Canadian seigneurs /53/ and, having retained a sentimental attachment to France, looked forward to the reconquering of the province. Indeed, in order to avoid trouble with these canadians, the colonial government declared, when war came between Britain and France in 1793, that the hostilities were against the

52 Greenwood, "Garrison Mentality," 48-50, 51-52, $54-55,56-58$.

53 After the cession of Canada to the British in 1763, many English merchants and officials purchased seigneuries. Greenwood, "Garrison Mentality," 67. 
French Revolution and not against France itself. Still, the British believed that the canadian lower class would support any French invasion force that might appear. /54/

These fears found validation in an incident that occurred in the winter of 1793-1794. After Meziere was carried off in October to France, his agent, Rous, went ahead and distributed copies of Genet's Les Francais lebres a leurs freres les Canadiens; a copy fell into the hands of Attorney General James Monk in January and the colonial authorities were greatly alarmed by what they perceived as the pamphlet's success. /55/ Soon thereafter came the Militia Act riots which were precipitated by the growing tensions in Anglo-American relations.

In the early 1790 's, the Americans in Vermont were encroaching upon the disputed territory along the United states-Canadian border. Because of this and other reasons, Lower Canada's governor, Lord Dorchester, was, by February, 1794, anticipating a war with the Americans and, in May, the Vermont militia, led by Ira Allen, was virtually beseiging the British garrison at Pointe au Fer. /56/

54 Michel Tetu, "Quebec and the French Revolution," 3-4; Greenwood, "Garrison Mentality," 50, 59-63, 66, 69.

55 Kingsford, The History of Canada, 387 ; Wade, "Quebec and the French Revolution," 364-366. 
Therefore, Dorchester ordered the embodiment under the colony's new Militia Act of 2000 men in case war broke out. /57/ The British method of raising troops by balloting was unfamiliar to the Canadians, many of whom feared that it entailed military service for life and possible duty in the West Indies while others indicated a desire to remain

The Act declared all men in the colony between the ages of 18 and 60 , with certain exceptions, to be militiamen bound to serve in the militia of the community in which they resided. The militia, or any part thereof, could be called out only in cases of war, insurrection, and other emergencies, and, even then, only for a period of time not to exceed six months. Furthermore, except in very specific cases, the units could not be ordered to serve out of Lower Canada. Finally, if circumstances permitted and less than the whole militia was needed, a quota was given to every division, battalion, and company to fill and the determination of who was to actually serve would be determined by lot. "An Act to provide for the greater security of this Province, by the better regulation of the Militia thereof, and for repealing certain Acts or ordinances relating to the same," The Provincial statutes of Lower Canada, Enacted by the King's Most Excellent Majesty, by and with the Advice and consent of the Legislative council and Assembly of the Said Province, Constituted and Assembled by Virtue of and under the Authority of an Act of the Parliament of Great Britain, Passed in the Thirty-First Year of the Reign of our Sovereign Lord George the Third by the Grace of God, of Great Britain, France and Ireland, King, Defender of the Faith, \&, Vols. 1-2 (Quebec: William Vondenvelden, 1795-1797), 34 Geo. III, c.4, sections 1, 16-17, 21, and 29 , p. 1:35, 1:45-49, 1:51-53, 1:57. 
neutral with respect to any fight with the Americans. of the estimated 7000 Canadians fit for service, only 900 obeyed the law. /58/ In Quebec City, the Canadians broke "into a Mob, refusing to ballot or be commanded;" in nearby Charlesbourg and Beauport, a mob of 300 men armed with muskets, hunting knives, hayforks, and flails patrolled the streets for a few days lest "one come to enlist them;" and in Cote-des-Neiges, a party of Canadians had armed themselves and were determined to prevent their being taken away from their families. /59/

Dorchester attributed the Canadians' actions to the long disuse from military service and to his belief that, although the hand of government was gentle, dissatisfaction existed because the Canadian lower class was not adequately protected against the abuses of the seigneurs as they had

58 Kingsford, The History of Canada, 385-387; Wade, "Quebec and the French Revolution," 366; Flenley, "The French Revolution and French Canada," 60.

59 Wade, "Quebec and the French Revolution," 367 ; Canadian Archives, Series Q, Vol. 69, 309-314, and Vol. 69-2, 256-257, both in wade, "Quebec and the French Revolution," 366-367; Kingsford, The History of Canada, 387 . 
been (or so Dorchester believed) under the French colonial administration. /60/ Therefore, he refused to be panicked by Attorney General Monk into using regular British troops to quell the riots and, when the expected attack from Vermont did not happen and the anticipated French fleet failed to appear, the agitation collapsed. /61/ But Monk, who had a strong intolerance for civil disobedience, concluded (as well as many others) that the unrest had been created by French revolutionaries and American subversives. On May 31, 1794, Monk secured the passage in the colonial legislature of what is now known as the Alien Act which, for one year, forbade the unauthorized entry into Lower Canada of foreigners, permitted their

The English seigneuries regarded the Canadian farmers who were residing on the land as tenants rather than as co-owners holding the property in perpetuity. Therefore, they often tried to revise the existing contracts and imposed any conditions on the new settlers who wished to farm the land that the economic conditions would allow. Although the English were the worst offenders, many Canadian seigneurs were also engaging in these practices in the 1790 's. Greenwood, "Garrison Mentality," 67-68.

61 Kingsford, The History of Canada, 386, 397; Wade, "Quebec and the French Revolution," 367. 
summary deportation, and suspended habeas corpus when

treason was suspected. /62/ The Act also made it illegal

for anyone to:

hold seditious discourses, utter treasonoble [sic] words, maliciously spread false news, publish or distribute libellous [sic] or seditious papers written or printed, tending to excite discontent in the minds, or lessen the affections of his Majesty's subjects, or in any manner disturb the peace and happiness enjoyed under his Majesty's Government in this Province. /63/

Between May and November, 1794, 50 to 100 leaders of the riots were arrested under the Act, but few were brought to

Kingsford, The History of Canada, 397, 399; James H. Lambert, "Sir James Monk," in Dictionary of Canadian Biography Vol. 6 (Toronto: University of Toronto Press, 1987), 512.

Habeas corpus generally refers to the variety of writs used to release a person from unlawful imprisonment; the prisoner's guilt or innocence is not at issue, but whether he is being restrained in a manner consisted with the due process of law. A suspension of habeas corpus means that a person can be imprisoned without being tried, charged with a crime, or released on bail. Henry Campbell Black, Joseph R. Nolan, and M.J. Connolly, Black's Law Dictionary: Definitions of the Terms and Phrases of American and English Jurisprudence, Ancient and Modern, Sixth Edition (St. Paul: West Publishing Company, 1979), 638-639.

63 "An Act for establishing regulations respecting Aliens and certain subjects of his Majesty, who have resided in France, coming into this Province, or residing therein; and for empowering his Majesty to secure and detain persons charged with or suspected of High Treason; and for the arrest and commitment of all persons, who may invdividually [sic], by seditious practices, attempt to disturb the Government of this Province," The Provincial statutes of Lower Canada," 34 Geo. III, c.5, section 31, p. 1:71. 
trial for fear of further rioting and many spent several months in prison without ever being tried. Indeed, when some of those arrested were brought to trial in september, more disturbances broke out in Montreal; the English thought that the whole city was, once again, up in arms, but the trouble quickly subsided. /64/

To eliminate one cause of Canadian unrest, Monk also obtained the passage in December, 1794 of a statute that strengthened the legal protections for the Canadian farmers against the practices of the seigneurs. Finally, he initiated social groups in Montreal, Quebec City, and Three Rivers which promoted allegiance to Britain by discouraging riots, identifying those whose loyalty was questioned, and making sure that the Canadians knew the horrors of the French Revolution. Known as the "Associations," these bodies were controlled mainly by the prominent English officials and merchants in the above communities and, as a result of their work, Monk was able to arrest suspected agitators without fear of provoking unrest. /65/

In May, 1795, in order to test public feeling, Dorchester again ordered the militia to be called out and,

64 Greenwood, "Garrison Mentality," 125-126, 129-130.

65 Lambert, "Sir James Monk," DCB, Vol. 6, 512; Greenwood, "Garrison Mentality," 127-128. 
as before, many Canadians were unwilling to serve and resisted. Arrests were made in Charlesbourg and Montreal and when the French troops that were, according to rumors, to enter Canada between the 8 th and 19 th of June failed to appear, the unrest evaporated. /66/

Finally, in 1796, the Road Act was adopted obligating the canadian farmers to build and maintain public roads bordering on their properties through a system similar to what had built the Quebec-Montreal highway during the old Regime. For the Canadians, it was a point of pride to be exempt from state taxation, but being responsible for the construction and upkeep of the roads adjoining their property smacked of just that. Resistance broke out in early October and again in January and March of 1797 and the new colonial governor, sir Robert Prescott, Monk's successor, Attorney General Jonathan Sewell, and many others believed that the opposition to the Road Act was orchestrated by emissaires sent by Adet. In Quebec, the arrest of a few leaders quickly restored order, but in Montreal, the weak resolve of the local magistrates encouraged further unrest. Therefore, Prescott fired many 
of the timid justices of peace and, on sewell's recommendation, sent troops to Montreal. /67/

The Road Act riots, along with the Canadians' enthusiastic response to the French attack on Newfoundland and the arrival of the news, in January, 1797, of the capture of the olive Branch, left the English with the impression that the canadians were under the influence of French agents and their sympathizers and that the colony was on the verge of a rebellion. The section of the Alien Act which suspended habeas corpus expired in 1795 and was not renewed, but it was now the view of the British that it was necessary to reinstitute it; however, in what many Englishmen considered as a vote for treason by the Canadians, the colonial government lost its majority in the legislature in the 1796 election to those who were

"An Act for making, repairing and altering the Highways and Bridges within this Province and for other purposes," The Provincial statutes of Lower Canada, 36 Geo. III, c. 9, Sections 1-3, p. 1:218-220; Flenley, "The French Revolution and French Canada," 61; Fernand Ouellet, Lower Canada, 1791-1840: Social Change and Nationalism, trans. by Patricia Claxton (Toronto: McClelland and stewart Ltd., 1980), 45-46; Wade, The French Canadians, 101; Christie, A History of the Late Province of Lower Canada, 172; Bymner to Carling, December 31, 1891, in Brymner, "Introduction," xl-xli; F. Murray Greenwood and James $H$. Lambert, "Jonathan Sewell," in Dictionary of Canadian Biography, Vol. 7 (Toronto: University of Toronto Press, 1988), 783. 
suspected of disloyalty. Therefore, a strategy was devised that included the arrest for high treason, in February and early March, 1797, of the only three Canadians (Jean-Bapiste Bizette and du Calvette's uncle and grandfather, Etienne and Joseph Girard dit Provencale) known to have Iistened to du Calvette's message the previous september, thereby revealing at an opportune time a "plot" for the seizure of Canada. /68/ In the last week of April, a bill sponsored by Attorney General sewell was enacted; commonly known as the Better preservation Act, it permitted the arrest and the detention until May, 1798, without the benefit of bail or trial, of anyone suspected of treason or treasonable practices. A few days later, on May 1, 1797, just as the canadians in the legislature were

68 Greenwood, "Garrison Mentality," 39, 39n38, 103-104, 130-131, 133-134, 137n104, 137, 139-142; Greenwood, Legacies of Fear, 147; Brymner to Carling, December 31, 1891, in Brymner, "Introduction," xl-xlii; "An Act for establishing regulations respecting Aliens, The Provincial statutes of Lower Canada, 34 Geo. III, c.5, section 36, p. 1:77; An Act for further continuing certain parts of an Act passed in the thirty-fourth year of His Majesty's reign, intituled [sic], 'An Act for establishing regulations respecting Aliens and certain subjects of his Majesty, who have resided in France, coming into this province or residing therein, and for empowering his Majesty to secure and detain persons charged with or suspected of High-Treason; and for the arrest and commitment of all persons, who may individually, by seditious practices, attempt to disturb the Government of this Province, " The Provincial statutes of Lower Canada, 36 Geo. III, c. 8 , section 1, p. 1:216. 
about to amend the Road Act, Governor Prescott prorogued the body. /69/ And then, on May 10th, David McLane was arrested in Quebec City.

69 Greenwood, "Garrison Mentality," 140-142; "An Act for the better preservation of His Majesty's Government as by Law happily established in this Province," The Provincial statutes of Lower Canada, 37 Geo. III, c. 6 , sections 1-4, p. 2:20-22.

A prorogation of the legislature brings the current legislative session to an end, terminates all pending business, and sets the date for the next session of the legislature to begin. In contrast, a dissolution brings the legislature completely to a close and an adjournment, which is done only at the discretion of the legislature itself, suspends the business of the legislature for a fixed time and does not terminate any pending matters. Walter $s$. Scott, The Canadian Constitution Historically Explained (Toronto: The Carswell Company, Ltd., 1918), 109. 
CHAPTER V

THE LIFE OF DAVID MCLANE

Not much is known about David McLane's early life. He was probably born to Daniel Mclane, Sr., and Mary McLane in Dedham, Massachusetts sometime in the 1760's. /70/

Depending on when when he was born, Mclane may have been

70 The exact date and location of McLane's birth are unknown.

Two nineteenth century amateur historians, Walter R. Danforth and John Gilmary Shea, both argued that Mclane was born "David Lane" in Attleboro, Massachusetts and that Mclane added the prefix to his name in order to enhance business while traveling through the American South. Neither Danforth nor shea indicate when McLane was born or give any indication as to his age. At least one twentieth century historian, Chilton Williamson, has accepted these claims without question. However, Danforth was relying upon his own personal recollection of events and while he professed to "recollect distinctly local events transpiring as far back as fifty-seven years," he was off by ten years as to the date of McLane's execution. Likewise, while shea indicates that he was relying upon the recollection of $\mathrm{J}$. Ward Dean, his work and Danforth's are virtually verbatim of each other. Walter R. Danforth, "Pictures of Providence in the Past, 1790-1820: The Reminiscences of Walter $R$. Danforth," ed. Clarkson A. Collins, 3 rd. Rhode Island History 10:3 (July, 1951): 93-96; John Gilmary Shea, "David Mclane, An American Executed for High Treason at Quebec in 1797," The New England Historical and Genealogical Register for the Year 186216 (October, 1862): 321-323; [Anonymous, probably John Gilmary Shea] "Trial and Execution of David McLane, an American, for High Treason, at Quebec in 1797," 
70 (continued)

The Historical Magazine and Notes and Queries Concerning the Antiouities, History and Biography of America 7:5 (May, 1863): 137-141; Williamson, vermont in Quandary, 232 .

There was a David Lane born in Attleboro on April 30, 174I. However, if this is the David McLane who was hanged for treason, then Mclane would have been 56 years old at the time of the trial, which is much older than Mclane's contemporaries describe him. The anonymously written Trial, Condemnation and Horrid Execution of David M'Lean states that Mclane was about thirty years old at the time of his execution and, at the trial, prosecution witness John Black testified that Mclane had said that Black might "think me young - . for such an enterprise, but this is the system France pursues at present; she will not employ an old general." No other David Lane was found that was born in Attleboro in the eighteenth century. Church of Jesus Christ of Latter Day Saints, "Massachusetts: Lamb, John Jero - Larrance," International Genealogical Index 1992 Microfiche 0-0616; [Anonymous], Trial, Condemnation and Horrid Execution of David M'Lean, 12; Testimony of John Black, July 7, 1797, quoted in 26 state Trials $721,778$.

Besides Attleboro, other locations have been suggested as the place of Mclane's birth. The author of Trial, Condemnation and Horrid Execution of David M'Lean indicates that McLane was a native of Ayrshire, scotland and prosecution witness Thomas Butterfield swore at the trial that McLane said that he had been born in Boston. [Anonymous], Trial, Condemnation and Horrid Execution of David M'Lean, 12 ; 26 State Trials 721, 773. However, Dedham, Massachusetts is the most likely spot. McLane's brother, Daniel, made a deposition in 1797 which indicated that Daniel was born in "Dedham about Twelve Miles from Boston." Indeed, a Daniel McLane, $\mathrm{Jr}$. was born in Dedham to Daniel McLane, Sr. and Mary McLane on December 18, 1754. It should also be noted that when Daniel was arrested by the British for planning to break his brother out of jail, he was using the alias of "Joseph Worthington;" the surname of Mary McLane before her marriage to Daniel, Sr. was "Withington." Also, David McLane, just before his arrest, used the alias "Jacob Felt" and, during his trial, identified the real Felt as his brother-in-law. Also, in his deposition, Daniel McLane identified Felt 
raised during his teens by his eldest brother Daniel or by one of his other siblings. /71/ He might also have served

70 (continued)

as his half-brother. On May 15, 1765, a Mary McLane married Jonathan Felt in Stoughton, Massachusetts, just a few miles from Dedham, and, on March 23, 1768, they had a son, Jacob. It is not clear whether the Mary McLane who married Felt was David's mother or sister; David's mother died on April 12, 1781 and the Mary McLane who married Felt died sometime during that same year. Daniel McLane, Sr., died on May 16, 1777 and no indication is available to indicate that the McLanes were ever divorced. However, no birth record for a daughter named Mary is available either. Deposition of Daniel McLane, May 22, 1797, Canadian Archives, Series Q, Vol. 79-1, 129, in Douglas Brymner, "French Republican Designs on Canada," chap. in Report on Canadian Archives (ottawa: S.E. Dawson, 1892), Note D, 72; 26 State Trials 721, 780; Church of Jesus Christ of Latter Day Saints, Baptisms for the Dead, Book H, 1896-1897 (Salt Lake Temple Records, salt Lake City. Filmed by the Genealogical Society, Salt Lake City, Microfilm 183417) pg. 66, 412; Church of Jesus Christ of Latter Day Saints, Baptisms for the Dead, Book 5N, 1935 (salt Lake Temple Records, Salt Lake City. Filmed by the Genealogical Society, salt Lake City, Microfilm 183554) p. 399; Church of Jesus Christ of Latter Day Saints, "Massachusetts: Faunce, Elmina - Fest, Catherine," International Genealogical Index 1992 Microfiche 0-0572; Church of Jesus Christ of Latter Day Saints, "Massachusetts: McKenna, May Merrick, Charles," International Genealogical Index 1992 Microfiche 0-0628.

71 As already noted in footnote 70, Mary McLane died in 1781 and her husband passed away four years earlier. Besides Daniel, David McLane's other known siblings were Benjamin, born February 9, 1756, Oliver, born July 25, 1757, and Deliverence, born August 24, 1759. Church of Jesus Christ of Latter Day Saints, "Massachusetts: McKenna, May - Merrick, Charles," International Genealogical Index 1992 Microfiche $0-0628$. 
as a private in the Continential Army during the American

Revolution. /72/ In any case, Mclane settled in

Providence, Rhode Island sometime between 1782 and 1790 ,

possibility after living in Pennsylvania. /73/ McLane was

72 Seven individuals, all named "David McLane," and one named "David McClean," served as privates in various Massachusetts units between 1776 and 1785 . The term of enlistment was usually short, ranging from 13 days to nine months. However, the last enlistment, in 1782, was for three years. None of the dates of service overlap, so it is possible that all of these persons are the same individual. Unfortunately, there is not enough information to indicate whether any of them are the David McLane who was hanged in Quebec City in 1797. Massachusetts Soldiers and Sailors of the Revolutionary War, Vol. 10 (Boston: Wright and Potter Printing Company, 1902), 431, $537-538$.

73 No David McLane (M'Lane, McLean, or any other spelling) is listed in either Rhode Island's 1777 Military Census or in Rhode Island's 1782 Census, although the data for six towns are missing from the first census and for two others from the second. A "David McClain" is listed in the 1790 Federal Census for Providence, Rhode Island; directly underneath his name is that of Paul Draper who, as mentioned later, was McLane's business partner and whose family lived with Mclane's family. There is no other David McLane, by any spelling, listed in the 1790 census for Rhode Island. Mildred M. Chamberlain (ed.), The Rhode Island 1777 Military Census (Baltimore: Genealogical Publishing Company, 1985); Jay Mark Holbrook, Rhode Island 1782 Census (Oxford, MA: Holbrook Research Institute, 1979); Heads of Families at the First Census of the United states Taken in the Year 1790: Rhode Island (Washington: Government Printing office, 1908 ; reprint, Baltimore: Genealogical Publishing Company, 1966), 33, 62 .

It may be possible to pin down the date of Mclane's move to Providence to late 1790. The enumeration for the 1790 Federal Census began on the 
73 (continued)

first Monday of August, 1790 and, in order to arrive at an accurate count, each person's usual place of abode was regarded as their home as of that date. Nationwide, the census was scheduled to take nine months to complete, but the counting in Providence was finished before January 29, 1791. The 1790 census for Providence lists a "David McClain" and three free white females among the city's inhabitants. However, the 1790 census for Boston also lists a "David McClean" and three free white females within that city's residents. While there is not sufficient information to prove that these are the same family, it is possible that Mclane was counted in Boston and then, after moving to Providence, was counted again. Contrary to this theory is the testimony, if credible, of prosecution witness Elmer Cushing who stated at McLane's trial that when he knew Mclane eleven years earlier (i.e., 1786), Mclane was residing in Providence. However, besides the fading of memory over time, there may be other reasons to question this testimony. (See footnote 111) Heads of Families, 1790: Rhode Island, 33; Heads of Families at the First census of the United States Taken in the Year 1790:

Massachusetts (Washington: Government Printing Office, 1908; reprint, Baltimore: Genealogical Publishing Company, 1966), "Introduction (Unenumerated)," 4, 185; Providence Gazette and Country Journal, 29 January 1791; 26 state Trials $721,769$.

The only suggestion that Mclane ever resided in Pennsylvania comes from the title page of Trial, Condemnation and Horrid Execution of David M'Lean. However, the author of that pamphlet may have confused David Mclane with his brother, Daniel, who was a resident of Pittsburgh, was arrested in Quebec a week after David Mclane, and was falsely rumored to have also been executed. Deposition of Daniel McLane, May 22, 1797, Canadian Archives, Series Q, Vol. 79-1, 129, in Brymner, "French Republican Designs on Canada," Note D, 72 ; Greenwood, Legacies of Fear, 146; Wilber, Ira Allen, 2:139. 
married at least three times. /74/ The first known wife, Rebecca, died in Providence "in the 26th Year of her Age" in late April, 1791 and she was probably one of the three "free white females" who were listed by the Federal Census as living with McLane in 1790; the two others are presumably McLane's daughters. /75/ The next wife was sixteen year old Cynthia Davis of Carleton, Massachusetts whom McLane married on February 16, 1792; she died on October 10, 1793, three months after giving birth to a daughter. /76/ McLane's last wife was Mrs. JoAnne DeEechant (also spelled "de Eeckoot) whom he married at the

In addition to the three known marriages, Mclane may have been married on two other occasions. A "David McLane" and Sarah Bullman registered, on February 3, 1782, their intention to marry and a "David Mclean" married Hannah Page on November 26 , 1786. Both of these events occurred in Boston. However, there is not enough information available to determine if this is the same "David McLane" who was hanged in Quebec City. Edward W. McGlenen, ed., Boston Marriages from 1700 to 1809 (for 1752-1809) (Baltimore: Genealogical Publishing Company, 1977), 391,445 .

75 Providence Gazette and Country Journal, 30 April 1791; Heads of Families, 1790: Rhode Island, 33 .

76 Providence Gazette and Country Journal, 12 October 1793; Church of Jesus Christ of Latter Day Saints, Baptisms for the Dead, Book 6E, 1937-1938 (Salt Lake Temple Records, salt Lake city. Filmed by the Genealogical Society, salt Lake City, Microfilm 183571) p. 584; Church of Jesus Christ of Latter Day Saints, "Massachusetts: Dana, Catherine - Davis, Edmund," International Genealogical Index 1992 Microfiche 0-0559; Church of Jesus Christ of Latter Day Saints, "Massachusetts: McKenna, May - 
First Congregational Church in Providence on July 13, 1794 ; related to the Belshire (or Belcher) family of Newport, Rhode Island, she survived McLane and there is no indication that they had any children. /77/

Mclane was a particular type of carpenter known as a "housewright" and, as such, he specialized in the construction of houses and similar buildings. He probably worked with his hands, but he might also have directed and organized other workers; he could also have designed the structures himself or have constructed the buildings according to a concept or design chosen by his clients. /78/ At some point, he and Paul Draper became partners

76 (continued)

Merrick, Charles," International Genealogical Index 1992 Microfiche 0-0628; Church of Jesus Christ of Latter Day Saints, "Rhode Island: Madsen, George McAndrew, Ann," International Genealogical Index 1992 Microfiche $0-1417$.

77 City of Providence, Rhode Island, Vital Statistics, Book Five, p. 391, in the possession of Division of Archives and History, City Hall, Providence, Rhode Island; Providence Gazette and Country Journal, 19 July 1794; City of Providence, Rhode Island, "Re: David Mclane, \#A1673," Probate Proceedings, Book one, p. 9, in the possession of Division of Archives and History, City Hall, Providence, Rhode Island; 26 state Trials 721, 781; [Anonymous, probably Shea], "Trial and Execution of David McLane," 138. Shea, "David McLane, An American," 321-322; Greenwood, Legacies of Fear, 140-141; Joseph K. Ott, "Rhode Island Housewrights, Shipwrights, and Related Craftsmen," Rhode Island History 31:2-3 (May and August, 1972): 65 . 
and, for at least two years, their families resided together. Mclane and Draper built (although they did not design) what was known as the Exchange coffee House. This structure was considered something of an architectural achievement with the rafters (or supporters) of the roof laid upon the plates (or the frame) of the building instead of being let into them by the use of mortices and tenons as was then the general practice. /79/ The first floor of the coffee House served as a non-alcoholic bar and as a place where the local merchants, politicians, and others could mingle or relax when the weather prevented their rendezvous on the Great Bridge in Providence; the second floor was for dining and the third was for lodging and friendly games of billards and cards. /80/

Mclane, for a while, prospered and became wellconnected; he started describing himself in real estate deeds as a gentleman, he was elected three times (October, 1792, May, 1793, and June, 1794) by the Rhode Island General Assembly to serve as a Major in the Providence Independent Light Dragoons, and he and Draper built at

79 Heads of Families, 1790: Rhode Island, 33 ; Providence Gazette and Country Journal, 13 November 1790, 11 February 1792, 1 September 1792 ; Danforth, "Pictures of Providence," 93-95; Shea, "David McLane, An American," 321-322; Greenwood, Legacies of Fear, 140-141. 
least four structures, including the coffee House (which, like three others that they built, was on land owned by the state's governor, Arthur Fenner, and located opposite the Market House that also served as the Providence Town Hall). However, the coffee House was ahead of its time and it did not succeed. Whether because of that or for other reasons, the McLane and Draper families put up their house for sale in February, 1792 and, on August 15, 1793, their partnership was dissolved and their creditors were instructed to look to McLane for the settlement of their accounts. In 1794, Mclane and Draper either sold or mortgaged four buildings that they had constructed, including the coffee House. /81/

Mclane, however, retained some sort of interest in the Coffee House. In January, 1795, the state legislature authorized him to conduct a lottery to raise funds for the completion and furnishing of a hotel that was being added

81 Greenwood, Legacies of Fear, 140; Joseph Jencks Smith, ed., Civil and Military List of Rhode Island, 1647-1800: A List of All Officers Elected by the. General Assembly from the organization of the Legislative Government of the Colony to 1800 (Providence: Preston and Rounds, 1900), 512, 522, 537 ; Providence Gazette and Country Journal, 7 May 1791, 11 February 1792, 1 September 1792, 17 August 1793; City of Providence, Rhode Island, Index to Deeds, 1677-1872: Mortgages to 1845, 916, in possession of the Division of Archives and History, City Hall, Providence, Rhode Island. 
to the structure. At five dollars a piece, 8000 tickets were to be sold and, from the $\$ 40,000$ raised, $\$ 4,000$ was to go to the hotel and the rest to prizes. Mclane took it upon himself to conduct the lottery and the enterprise was announced to the public on April 25th. /82/ But McLane tried to cut a few corners and rumors about the lottery spread. In May, the legislature required McLane to post bonds to insure the appropriation of the proceeds, something that he had already told the public in his advertisements that he had done. /83/ And then, in order to:

$$
\begin{aligned}
& \text { remove all unfavourable [sic] Impressions from } \\
& \text { the Minds of the Public, which the groundless } \\
& \text { Suggestions of Ill Nature may have made } \\
& \text { respecting the Management and Drawing of the } \\
& \text { EXCHANGE LOTTERY /84/ }
\end{aligned}
$$

Mclane published in the local newspaper a certificate, dated May 11th, certifying that he had, on that date, posted the required bonds with sureties. He also assured the public that:

all Securities and Monies received for Tickets will be lodged in the Bank, for the Payment of

82 John H. Stiness, "A Century of Lotteries in Rhode Island, 1744-1844," Rhode Island Historical Tracts 2nd serv., 3 (1896): 59-60; Providence Gazette, 25 April 1795.

Stiness, "A Century of Lotteries," 60; Providence Gazette, 27 February 1795. 
the Prizes, before the Time set for the Drawing of said Lottery. /85/

The notice further promised that the lottery would be held on september 3 rd and it named three prominent merchants who would "supervise and conduct the whole Business" as well as, in an attempt to sell more tickets, announce that the winning numbers from another lottery would be accepted as payment for tickets in Mclane's lottery. /86/ That advertisement, however, did not help the faltering project; the lottery was drawn on the scheduled date, but not all of the tickets had yet been sold and sales continued for at least another three weeks. When the results of the lottery were finally announced on october loth, only 2208 tickets had been sold and $\$ 11,040$ raised, far short of the $\$ 36,000$ needed to pay off the winners. In the end, few of the prizes were paid. /87/

But that was not the end of the lottery scheme for McLane's bonds apparently did not cover the out-of-pocket expenses for running the lottery. /88/ Also, by February, 1796, Mclane had:

in the most unusual Manner, without any Notification in any public Paper, for Reasons

$\begin{array}{ll}85 & \text { Ibid. } \\ 86 & \text { Ibid. }\end{array}$

87 Ibid., 12 and 19 september 1795, 10 October 1795; Danforth, "Pictures of Providence," 96. Providence Gazette, 27 February 1796. 
best known to himself, formed what he calls a second Class of the said [i.e., his 1795]

Lottery, proposing to raise a further sum of Four Thousand Dollars, and is in Fact

attempting to sell Tickets therein. /89/

An advertisement that was run by several businessmen warned the public of what Mclane was doing and killed whatever chances he had at making this second lottery a success. 190/ It is not clear how Mclane supported himself while conducting the lottery; at his trial, he said that he had been a storekeeper in partnership with his brother-in-law, Jacob Felt, but that this enterprise failed and McLane found himself besieged with debt. /91/ At one point, he considered becoming a highwayman, /92/ but by April, 1796, he was a French spy.

Ibid.

90 Ibid., 27 February 1796, 5 and 12 March, 1796.

9126 State Trials $721,780-781$.

92 Danforth, "Pictures of Providence," 96. 
CHAPTER VI

MCLANE'S RECRUITMENT OF FRENCH SYMPATHIZERS IN CANADA

It is not known where McLane stood in the debate as to whether the United States should have a pro-British or a pro-French policy nor whether he was a devoted follower of the French Revolution. Elmer Cushing, one of the men whom McLane tried to enlist as a fellow conspirator, would later write, among other things, that McLane espoused in November, 1797 the ideals behind Rousseau's theory of the social contract and vehemently censured the divine right of kings; however, Cushing's admitted purpose for writing his pamphlet in 1826 was to rectify the popular impression that he had testified against McLane in exchange for a township grant and, therefore, Cushing's tale must be viewed with some suspicion. Furthermore, there is the possibility that McLane had frequently stayed at Cushing's inn in Montreal since February, 1797, and that the two had been friends since the $1780^{\prime} \mathrm{s}$, so one has to wonder if McLane had expressed such political beliefs earlier and, if he 
had, why Cushing did not record these prior sentiments in his account of the events of $1797 . / 93 /$

It is not known when McLane had his first contact with the French. He may have been approached in 1793 when Genet instructed the consul in Boston to find a way to distribute the addresses and other propoganda that Genet was preparing. It is interesting that soon after Genet's spy, Henri Meziere, sailed for Canada on October 11, 1793, Genet received a letter from Montreal that was meant for Meziere. Written in very bad English, it mentioned, among other things, a "Mr. McLain in New York a printer that sends papers to Canada." There is, however, no available information as to who this "Mr. McLain" was. Mclane may have also met Adet when the latter passed through Newport, Rhode Island, in June, 1795, while on his way to Philadelphia as the new Minister to the United States. 194/ Whatever happened, McLane left Providence for the northwest tip of Vermont by April, 1796 and, thanks to the pre-trial despositions of the prosecution's witnesses, the

93 Elmer Cushing, An Appeal to a Candid Public: And to the Feelings of Those Whose Upright Sentiment and Discerning Minds, Enable Them to "Weigh It in the Balance of the Santuary" (Stanstead, Lower Canada [now Quebec], 1826), 3-30; Greenwood, Legacies of Fear, 142 .

See footnote 111 .

94 Wade, "Quebec and the French Revolution," 348-349; Providence Gazette, 13 June 1795; "Charles" to Meziere, October 24, 1793, L.O.C., France, Archives 
testimony at McLane's trial, and Adet's records, we are able to trace most of McLane's movements during the year before his arrest on May 10, 1797.

As a French agent, part of Mclane's mission was apparently to recruit sympathizers who could be relied upon when it came time to act and, between April, 1796 and May, 1797, Mclane approached at least eight individuals to solicit their help in "bringing about a Revolution in Lower Canada." /95/ In the apparent order in which they met Mclane, those eight were:

Thomas Butterfield (1746-1823), part owner of a sawmill in Swanton, Vermont (about five miles south of the border), /96/

94 (continued)

des Affaires strangeres, Correspondance politique, Etats-Unis, vol. 39, pt. 2, 414v-415, in Wade, "Quebec and the French Revolution," 360.

95 Quote from Deposition of William Barnard, December 1, 1796, Canadian Archives, Series Q, Vol. 78, 149, in Brymner, "French Republican Designs on Canada," Note D, 64-65.

Deposition of Thomas Butterfield, May 22, 1797, Canadian Archives, Series Q, Vol. 79-1, 125, in Brymner, "French Republican Designs on Canada," Note D, 71; Wilbur E. Garrett, ed., Atlas of North America: Space Age Portrait of a Continent (Washington: National Geographic, 1985), 162; Claire Weidemier McKarns, Personal Notes Regarding Her Ancestor, Thomas Butterfield, in possession of Claire Weidemier McKarns, Encinitas, California;

Marion Baxter, Application for Membership to the National Society of the Daughters of the American Revolution, Application Accepted and Approved February 8, 1922, copy in possession of Claire Weidemier McKarns, Encinitas, California. 
Francis chandonet, an acquaintance of Butterfield's and a Canadian expatriate living in the Lake Champlain area, /97/

William Barnard, a native of Deerfield, Massachusetts who came to Montreal in 1791 and became a shopkeeper, /98/

Charles Frichet (also spelled Frichette), an illiterate yeoman who resided in st. Johns (now st. Jean), Quebec (approximately twenty-five miles north of the U.S.-Canadian border and half way between Montreal and Lake Champlain) who, before April, 1797, had business dealings with Butterfield concerning lumber. /99/

Desposition of Thomas Butterfield, May 22, 1797, Canadian Archives, Series Q, Vol. 79-1, 125, in Brymner, "French Republican Designs on Canada," Note D, 71; 26 state Trials 721, 770-77I.

98 Deposition of William Barnard, December 1, 1796, Canadian Archives, Series Q, Vol. 78, 149, in Brymner, "French Republican Designs on Canada," Note D, 64-65; Greenwood, "The Treason Trial," 5 .

99 Claude Galarneau, "David McLane," in Dictionary of Canadian Biography, Vol. 4, (Toronto: University of Toronto Press, 1979), 502: Deposition of Charles Frichet, May 12, 1797, Canadian Archives, Series Q, Vol. 79-1, 13, and Deposition of Thomas Butterfield, May 22, 1797, Canadian Archives, Series Q, Vol. 79-1, 125, both in Brymner, "French Republican Designs on Canada," Note D, 69-70 and 71 , respectively. 
Elmer Cushing (d.1826), another native of Massachusetts who had come to Montreal with his family and became the owner of a tavern known as the American Coffee House, /100/

Silas Hathaway, a tavern owner in st. Albans, Vermont (approximately seven miles south of Swanton), /101/

Asa Holgate, a tavern owner in Swanton, Vermont, /102/

26 State Trials 721,766 ; Cushing, Appeal, 7 .

According to cushing, he emigrated from Massachusetts to Montreal in 1792; one source, however, indicates that he made the move as early as 1783. Cushing, Appeal, 7 ; Supplemental Information Card on Elmer Cushing, received from "rt" on 24 janvier 1983, in possession of the Dictionary of Canadian Biography, University of Toronto Press, Toronto, ontario.

Also, while only the names of households were taken down in the 1790 Federal Census, it should be noted that no Elmer Cushing is listed as residing anywhere in Massachusetts at the time of that census. Heads of Families, 1790: Massachusetts, 3, 274 .

101 Deposition of Thomas Butterfield, May 22, 1797, Canadian Archives, Series Q, Vol. 79-1, 125, in Brymner, "French Republican Designs on Canada," Note D, 71; Garrett, Atlas of North America, 162.

102 Deposition of Thomas Butterfield, May 22, 1797, Canadian Archives, Series Q, Vol. 79-1, 125, in Brymner, "French Republican Designs on Canada," Note D, 71 . 
and

John Black (c.1764-after 1819), a

Quebec City shipbuilder and politician. /103/

Four of these men would later willingly testify against McLane /104/ and Hathaway would betray McLane's cause to the United States Government. /105/ That fact might seem to indicate that McLane was not very careful about whom he approached, but upon closer examination, it appears that Mclane had good reason to believe that each of them would join his plot for revolution.

For example, Thomas Butterfield was a resident of northwest Vermont as early as 1770 and served as an officer in the Green Mountain Boys during the war for Independence: /106/ He was also the founder of Swanton, Vermont, had

103 F. Murray Greenwood, "John Black," in Dictionary of Canadian Biography, Vol. 5 (Toronto: University of Toronto Press, 1983), 83-84.

104 Barnard, Cushing, Chandonet, and Black.

Two others, Butterfield and Frichet, would also testify against Mclane, but as accomplices who were under arrest and in prison. 26 state Trials 721, 763-779; Greenwood, Legacies of Fear, 146, 154 .

Wilbur, Ira Allen, 2:120-121, 2:140, 2:150.

106 The Green Mountain Boys were a military organization founded in 1770 by the settlers of the New Hampshire Grants (now Vermont) to frighten off the New York surveyors and sheriffs who were attempting to impose their state's claim to the region. During the American Revolution, the settlers temporarily put aside their differences with New York and the Green Mountain Boys fought alongside the 
held a variety of local and state offices, was once Vermont's secret messenger to Quebec's government, and had spent some time in 1786 in the Quebec jail as a political prisoner. Furthermore, Butterfield was a long-time employee and political follower of Ira Allen and was, when McLane approached him, the operator and co-owner of the Allen sawmill in Swanton. /107/

Francis Chandonet was also a likely candidate to join McLane's efforts. A Canadian by birth, he left the colony, after having been promised a military commission, when the

106 (continued)

Continental Army against the British. David Maunsell, Lawton V. Crocker, and Dorman B.E. Kent, Gazetteer of Vermont Heritage (Chester, VT: The National Survey, 1966), 7-10.

107 Jay Mark Holbrook, Vermont 1771 Census (Oxford, MA: Holbrook Research Institute, 1982), 15; Jay Mark Holbrook, Vermont's First Settlers (Oxford, MA: Holbrook Research Institute, 1976), 16; Abby Maria Hemenway, Vermont Historical Gazetteer, A Local History of All the Towns in the state: Civil, Educational, Biographical, Religious, and Military Vol. 4 (Montpelier: Vermont Watchman and State Journal Press, 1882), 994, 996-997, 999, 1016, 1106, 1132-1133, 1185, 1187; John E. Goodrich, ed., The state of Vermont: Rolls of the soldiers in the Revolutionary War, 1775 to 1783 (Rutland, VT: The Tuttle Company, 1904), 860; Wilber, Ira Allen, $1: 411,1: 459,1: 490-491,1: 513,2: 59$; Deposition of Thomas Butterfield, May 22, 1797, Canadian Archives, Series $Q$, Vol. 79-1, 125, in Brymner, "French Republican Designs on Canada," Note D, 71; McKarns, Personal Notes on Thomas Butterfield; Baxter, Application for Membership in the Daughters of the American Revolution. 
Continental Army retreated from Quebec in 1776; indeed, he served as an ensign for two years, and then as quartermaster-general, in the first New Hampshire Regiment and became a naturalized citizen. Furthermore, McLane had learned (possibly through Butterfield, who knew Chandonet) that Chandonet was going to live in the village of st. Regis, New York, a site not far upstream from Montreal; he may also have known that Chandonet had recently been deported from Upper Canada as an undesirable alien and was forced to leave a farm behind./108/

Not much is now known about william Barnard except what is indicated above. Mclane, however, apparently had more information, for when he introduced himself to Barnard, he:

related to this Deponent [Barnard] several circumstances which had happened to him before he came to settle in the Province of Lower Canada, which convinced this Deponent

10826 State Trials 721, 770-771; Francis B. Heitman, Historical Register of officers of the continential Army during the War of the Revolution: April, 1775, to December, $1783 \mathrm{New}$, Revised, and Enlarged Edition (Washington, Rare Book Shop Publishing Company, 1914), 150; Chandler E. Potter, The Military History of the State of New Hampshire, 1623-1861: Two Parts in One Volume (1866-1868, original publisher not known; reprint, Baltimore: Genealogical Company, 1972), Part one, 299; Deposition of Thomas Butterfield, May 22, 1797, Canadian Archives, Series Q, Vol. 79-1, 125, in Brymner, "French Republican Designs on Canada," Note D, 71. 
that the said McLean [sic] had taken pains to discover the real situation and circumstances of him the said Deponent. /109/

Little is also known about Charles Frichet but, like Barnard, Mclane knew Frichet's name and where to find him and must have had some reason to believe that Frichet would help. Indeed, according to John Black's pre-trial deposition, Frichet told Black (while taking Black to met McLane) that Frichet had accompanied others into canada in

Deposition of William Barnard, December 1, 1796, Canadian Archives, Series Q, Vol. 78, 149, in Brymner, "French Republican Designs on Canada," Note D, 64-65.

Barnard's assertion that he first met Mclane at Alburg, Vermont on July 26, 1796 must be viewed with suspicion. Both Barnard and McLane both knew Cushing and all three were natives of Massachusetts. More importantly, Mclane knew quite a bit about Barnard's life before Barnard emigrated to Montreal and, yet, Barnard's deposition would have us believe that McLane coincidently met Barnard, or was able to track Barnard down, in Alburg while Barnard was on his way back to Montreal. Deposition of William Barnard, December 1 , 1796, Canadian Archives, Series Q, Vol. 78, 149, in Brymner, "French Republican Designs on Canada," Note D, 64-65; Cushing, Appeal, 7, 15; Greenwood, Legacies of Fear, 143 .

Furthermore, Barnard at least realized the he might be regarded by others as one who might join a revolution, and he may have actually been inclined to do so, because when he first refused to join Mclane, the only reason he gave not going along was that:

this Deponent at that time thought it might be a Plot formed by his enemies to ruin him. Deposition of William Barnard, December 1, 1796, Canadian Archives, Series Q, Vol. 78, 149, in Brymner, "French Republican Designs on Canada," Note $D, 64-65$. 
the autumn of 1796 and that he knew of a French officer who was suppose to be sent to Quebec City instead of Mclane. Furthermore, Frichet allegedly told Black that it wasn't just McLane, but "French agents" who sent him on this journey. If true, then Frichet was deeply involved in a conspiracy that involved more than just David McLane. /110/

Deposition of Charles Frichet, May 12, 1797, Canadian Archives, Series Q, Vol. 79-1, 13, and Deposition of John Black, May 10, 1797, Canadian Archives, series Q, Vol. 79-1, 7, both in Brymner, "French Republican Designs on Canada," Note D, 69-70 and 67-69, respectively.

Although there is no information directly linking the two, Frichet's alleged trip into Canada in Autumn, 1796, appears to be at about the same time as De Miliere's expedition into the colony.

It should be also noted that, in his deposition of May 12, 1797 and at Mclane's trial, Frichet claimed that he was ignorant of Mclane's scheme until just before McLane's arrest, but such statements must be viewed with suspicion. As is discussed later, Frichet was arrested and charged with high treason with McLane on May loth. The next day, Frichet signed a voluntary deposition that did little harm to Mclane, but on May 12th, "being for the Benefit of his soul he ought to speak the Truth," Frichet signed a new examination in which he admitted guiding McLane to quebec City and corroborated Black's account of how McLane and Black first met. What, if any, promises had been made to Frichet in exchange for his testimony are not known, but he never was tried for treason. Deposition of Charles Frichet, May 12, 1797, Canadian Archives, Series Q, Vol. 79-1, 13, in Brymner, "French Republican Designs on Canada," Note D, 69-70; 26 State Trials 721, 774-775; Greenwood, Legacies of Fear, 146, 154 .

It is the accounts contained in the May 12 th deposition that are relied on in this paper. However, 
As to Elmer Cushing, not much is known that would recommend him as a revolutionary except that McLane knew him "about ten or eleven years." /111/

\section{0 (continued)}

included in that deposition are Frichet's claims of refusing to go along with McLane's plans the first time the two of them met, but then traveling nearly thirty miles (by canoe, according to Butterfield) across the international border on Butterfield's mere word that Mclane wanted to see him, his not knowing in April, 1797 why Mclane wanted to go to Quebec after being reminded of their meeting eight months before, his willingness to accompany McLane after obviously being lied to about Mclane's purpose for going there and after being instructed to call Mclane by a fake name, and, when on the outskirts of Quebec city, learning again that McLane was working for the French but continuing by McLane's side after being assured that no one is meant to be harmed. If these accounts are true, then they certainly indicate that Frichet was a very gullible person. Deposition of Charles Frichet, May 12, 1797, Canadian Archives, Series $Q$, Vol. 79-1, 13, and the Deposition of Thomas Butterfield, May 22, 1797, Canadian Archives, Series $Q$, Vol. 79-1, 125, both in Brymner, "French Republican Designs on Canada," Note D, 69-70 and 71, respectively.

111 Testimony of Elmer Cushing on July 7, 1797, in 26 State Trials 721, 766, 769; Cushing, Appeal, 7.

The extent of Mclane's relationship with Cushing is uncertain. Historian F. Murray Greenwood states that Cushing had "known McLane slightly in the United states and the latter [McLane] had frequently stayed at Cushing's inn during his many visits to the city dating back to February [1796]." Greenwood, Legacies of Fear, 142.

[Note: This is the only indication that I have found that McLane stayed at Cushing's tavern before November, 1796; unfortunately, Dr. Greenwood does not indicate where he got his information from nor why Mclane made these earlier visits. If Mclane had been 
111 (continued)

frequently visiting Montreal as early as that February, then it may be possible that he began working for Adet much earlier than July, 1796.]

However, in a pamphlet that Cushing published in 1826, Cushing wrote that he knew Mclane from "when carrying on his [McLane's] mercantile concerns in that town [Providence, Rhode Island]" at which time McLane "bore a most excellent character, as an honest, fair, industrious and respectable dealer." Cushing, Appeal, 15 .

And Cushing strongly hinted in the pamphlet that he and McLane had kept in touch during the years; when McLane first arrived at Cushing's tavern in November, 1796:

It could not be a matter of surprise at my receiving him with pleasure, particularly, when it is taken into consideration that I had previously learned that he had met with considerable losses in his business; and the sympathy which my own situation would cause me to feel towards a man in his condition.

These circumstances produced, with the renewal of our old acquaintance, an increased initimacy. Cushing, Appeal, 15.

It was then, according to cushing, that McLane divulged the reason why he was in Canada. However, when reading Cushing's account, it must be remembered that the admitted purpose of the pamphlet was to counter the public's impression, which was still tarnishing cushing's reputation 30 years after the trial, that cushing traded his testimony for a township grant. Cushing, Appeal, 3-6, 15, 28-30.

The fact that cushing had his pamphlet published in stanstead may be an indication of just how low cushing's reputation had reached; while the town is in Quebec, a mistaken impression as to the location of the U.S.-Canadian border led to the widely-held belief in the early nineteenth century that it was in Vermont. David Lavender, "Point of Genesis," in Fort Vancouver, David Lavender and Archie Satterfield, 
Silas Hathaway was a substantial landowner and

businessman in northwest Vermont as well as a member of one of the Democratic Societies in the state. /112/ He was

also a speculator in lands located in Lower Canada and lost

111 (continued)

National Park Handbook Series (Washington: Division of Publications, National Park Service, U.S. Department of the Interior, 1981), 102 .

112 The Democratic Societies of the 1790 s were organizations within the United States consisting generally of three groups: those who hated the excise tax system, those who feared and distrusted centralized government, and those who felt that the state and federal governments were overly influenced by conservatives who believed that direct rule by the people, or even the use of direct representation in government, was premature for the young republic and would lead to chaos. Over forty of these societies were formed between 1793 and 1798 across the United states, including at least four in vermont (although, apparently, none were ever established in McLane's home base of Rhode Island). The societies strongly supported the Franco-American alliance of 1778 and equally opposed England and Jay's Treaty. Furthermore, both Genet and the societies in Vermont had a strong interest in Canada and there is evidence that the Vermont societies and their leaders were involved in Genet's plans for the conquest of the colony; for example, it was a member of the Burlington, Vermont society that recommended Jacques Rous to assist Meziere in Canada and it is known that, when his attack fleet sailed in october, 1794, Genet hoped for a second, simultaneous invasion through the Richelieu River Valley by Vermont frontiersmen. There is no indication, however, that the societies played any role in Adet's plans for Canada. Link, Democratic-Republican Societies, 1790-1800, 3-6, 13-18, 127-133, 141-144; Greenwood, "Garrison Mentality," 26-27. 
big when the Lower Canadian government worked to remedy the abuses of land speculators. /113/

Asa Holgate had been, before 1794, a partner of Stephen Thorn in a mercantile business and had past business dealings with both Ira Allen and Silas Hathaway. In addition, like Butterfield, Holgate had held numerous state and city offices, often as Butterfield's immediate successor. /114/

The last of the eight was John Black. Because of his contacts with the Canadian labor class and his knowledge of French, he was hired as a spy by Attorney General Monk at the beginning of the Militia Riots in 1794. Posing as a French sympathizer, he was himself arrested in August of that year on the word of an informer who did not realize Black's true intentions and, because Monk did not intervene, Black remained in jail for seven months. After this incident, Black's English clientele turned away and his business failed. In 1796, he won a seat in the Lower Canadian House of Assembly; representing a district composed mostly of Canadians, he was elected by exploiting

Williamson, Vermont in euandary, 207, 219-222.

114 Hemenway, Vermont Historical Gazetteer, 4:1133, 4:1185; Wilber, Ira Allen, 2:163. 
the resentments of the voters and by portraying himself as an opponent of the government. /115/

McLane knew about the arrest as well as Black's standing within the Canadian community; when sent by McLane to fetch Black, Frichet, relying upon information that McLane had given him, asked "are you the Mr. Black that was in gaol [jail] in the year 1794?" /116/ and, after being told that he was, told Black that he was known by Adet to be "a Sufferer under the British Government" and that Adet had "great Dependance on this Deponent [Black], particularly as he [Adet] understood he [Black] had much Influence with the People." /117/ But what McLane apparently did not know were the actual circumstances behind the arrest nor that Black was seeking to regain the confidence of his old customers and the colonial government. /118/ As we shall see, confiding in Black was McLane's ultimate downfall.

11526 State Trials 721, 776; Greenwood, "John Black," 드, Vol. 5, 83-84.

116 Deposition of Charles Frichet, May 12, 1797, Canadian Archives, Series Q, Vol. 79-1, 13, in Brymner, "French Republican Designs on Canada," Note $D, 69-70$; Testimony of Charles Frichet, July 7, 1797, in 26 state Trials $721,776$.

117 Deposition of John Black, May 10, 1797, Canadian Archives, Series Q, Vol. 79-1, 7, in Brymner, "French Republican Designs on Canada," Note D, 67-69. 
In April, 1796, McLane met Thomas Butterfield somewhere along otter creek (which flows in a northwest direction for about 100 miles and empties into Lake Champlain near Vergennes, about forty miles south of Swanton); however, at this occasion, all that McLane and Butterfield supposedly talked about were canals and land and McLane only mentioned that he was heading for the border. /119/ What McLane did for the next three months is not known, but he eventually went north and tried to enlist William Barnard into helping bring about a revolution in Lower Canada. /120/ Barnard was recommended to McLane as

119 Deposition of Thomas Butterfield, May 22, 1797, Canadian Archives, Series Q, Vol. 79-1, 125, in Brymner, "French Republican Designs on Canada," Note D, 71; 26 State Trials 721, 773; Garrett, Atlas of North America, 162; Leon F. Seltzer, ed., The Columbia Lippincott Gazetteer of the World (Morningside Heights, NY: Columbia University Press), 1401 .

120 It is possible that McLane did not go to Canada alone; according to his brother's deposition, David McLane indicated that he had gone to Canada in 1796 in the company of their half-brother/brother-inlaw, Jacob Felt. Desposition of Daniel McLane, May 22, 1797, Canadian Archives, Series Q, Vol. 79-1, 129, in Brymner, "French Republican Designs on Canada," Note D, 72 .

See, also, footnote 70 . 
someone who could be trusted with a secret and, twice, McLane unsuccessfully solicited Barnard's assistance with promises of riches. The first attempt occurred on either July 26 th or 29th at Alburg, Vermont (about two miles south of the U.S.-Canadian border near Swanton) and the second was four or five days later in Montreal. /121/ It was probably at this time that McLane went to st. Johns where he solicited, also with promises of fortune, the help of Charles Frichet, but allegedly without success. /122/

12126 State Trials 721, 764; Deposition of William Barnard, December 1, 1796, Canadian Archives, Series Q, Vol. 78, 149, in Brymner, "French Republican Designs on Canada," Note D, 64-65; 26 State Trials 721, 763-764; Garrett, Atlas of North America, 44 .

See, also, footnote 109.

122 Deposition of Charles Frichet, May 12, 1797, Canadian Archives, Series Q, Vol. 79-1, 13, in Brymner, "French Republican Designs on Canada," Note D, 69-70; 26 state Trials 721, 773-774; Seltzer, The Columbia Lippincott Gazetteer, 1635.

Frichet testifed at McLane's trial that he was first approached by McLane in June, 1796, but his pre-trial deposition indicates that the meeting occurred in either July or August. Deposition of Charles Frichet, May 12, 1797, Canadian Archives, Series Q, Vol. 79-1, 13, in Brymner, "French Republican Designs on Canada," Note D, 69-70; 26 State Trials $721,773$.

Furthermore, in his deposition and in his testimony, Frichet claimed that he did not agree to participate in McLane's plot when they first met in 1796. However, when Mclane told Butterfield in 1797 to fetch Frichet, Mclane said that Frichet "would understand what he [McLane] wanted with him, as he Frichette knew him [McLane] very well." Neither the 
Mclane then went on to Montreal and stayed there through September until early october, calming the canadians (or so he later bragged to John Black) and single-handedly putting an end to the Road Act riots because "the People are not Ripe to go sufficient Lengths." /123/

By the middle of october, McLane was in Philadelphia receiving his first two payments from Adet. /124/ on November 5 th, McLane was back in Montreal trying, unsuccessfully, to entice Elmer Cushing into his plans with promises of wealth. While speaking to Cushing, McLane indicated that he would return to Montreal in the spring by way of New York. /125/ About two days later, McLane again met Barnard, but this time at La prairie (about nine miles

122 (continued)

depositions nor the testimony of Frichet or Butterfield indicate that there was any hesitation or questions on Frichet's part in 1797 when Frichet and Butterfield left to return to McLane. Deposition of Thomas Butterfield, May 22, 1797, Canadian Archives, Series Q, Vol. 79-1, 125, and the Deposition of Charles Frichet, May 12, 1797, Canadian Archives, Series Q, Vol. 79-1, 13, both in Brymner, "French Republican Designs on Canada," Note D, 71 and 69-70, respectively; 26 state Trials $721,772-774$.

123

$$
26 \text { State Trials 721, 778; Deposition of }
$$

John Black, May 10, 1797, Canadian Archives, Series Q, Vol. 79-1, 7, in Brymner, "French Republican Designs on Canada," Note D, 67-69. 
outside Montreal), and, like before, Barnard refused to participate. $/ 126 /$ Later that month, while on his way back to Philadelphia, McLane stopped at swanton where he again met Butterfield. /127/ This time, McLane revealed his intentions and was able to secure Butterfield's participation in his plot to seize Lower Canada. He also indicated an expectation to be back in Swanton the following April or early May. /128/ McLane also met with Silas Hathaway in St. Albans in the middle of that November and procured his support; Hathaway, in fact, agreed to be the conspirators' treasurer. /129/

126 Deposition of William Barnard, December 1, 1796, Canadian Archives, Series Q, Vol. 78, 149, in Brymner, "French Republican Designs on Canada," Note D, 64-65; Garrett, Atlas of North America, 44.

127 It is possible that Mclane may have approached others, now unknown, before meeting with Butterfield at this time. At Mclane's trial, Butterfield testified that, when he met McLane in November, he asked:

if he [McLane] had found any men that could be depended on, who were willing to join him: he answered yes, one Black or Blake, and that there was a number of others whom he had seen and conversed with. Testimony of Thomas Butterfield, July 7,1797 , quoted in 26 state Trials 721,772 . 26 state Trials 721, 771-772. Greenwood, Legacies of Fear, 30ln3, 302-303n16; wilber, Ira Allen, 2:120. 
And, sometime during the summer of 1796 , and again the following winter, McLane met Francis Chandonet, a Canadian expatriate, somewhere along Lake Champlain just south of the border. Like Barnard, Chandonet had been recommended to McLane as someone who might join a revolution in Canada, but Chandonet refused to go along both times. /130/ Mclane was back in Philadelphia by late December when he received his third payment from Adet; he was also in

26 state Trials 721, 769-770.

According to Chandonet's testimony, the first meeting occurred in the summer of 1796 at Watson's Tavern just "a little below the Isle Aux Noix," but only states that the second meeting occurred the following winter without specifying where. 26 state Trials $721,769$.

Judge Riddell places Watson's Tavern at Swanton, Vermont and says that Mclane met Chandonet there in the summer of 1796. American historian Ronald Smith indicates that McLane and Chandonet met near the Vermont border while McLane was returning to Philadelphia after meeting with Cushing in November. Neither Riddell nor Smith mention a second McLane-chandonet contact and it is not clear that they are referring to the same meeting. Riddell, "Canadian State Trials," 321; Ronald D. Smith, "Agent McLane: Lone Revolutionary in Canada" The Rocky Mountain Social Science Journal 12:2 (October, 1970): 77 .

As mentioned in footnote 127, McLane may have approached other individuals before this time who are unknown to us today. At Mclane's trial, Chandonet testified that Mclane said he had found a "large body" of Canadians who would rise up in an insurrection. 26 State Trials 721,770 . 
Philadelphia in late January, 1797, to receive his advance for a future mission that Adet had entrusted to him. /131/ In mid-March, McLane had left Pittsburgh in mid-March with his brother Daniel (who resided there) and met Adet in Philadelphia on April 7th (and probably received at this time a letter from Adet containing some, now unknown, promises to McLane and his family). The brothers arrived in New York shortly thereafter and, from there, they went to Albany, New York and then to st. Albans, Vermont where their sister and brother-in-law (one scovil or scovel) had recently moved to. During this trip, David McLane may have met Butterfield at Saratoga, New York. /132/

131 Greenwood, "The Treason Trial," 2n2.

132 Deposition of Daniel McLane, May 22, 1797, in Canadian Archives, Series Q, Vol. 79-1, 129, the Deposition of Thomas Butterfield, May 22, 1797, Canadian Archives, Series Q, Vol. 79-1, 125, and the Desposition of John Black, May 10, 1797, Canadian Archives, Series Q, Vol. 79-1, 7, all in Brymner, "French Republican Designs on Canada," Note D, 72, 71, and 67-69, respectively; Seltzer, The columbia Lippincott Gazetteer, 1703; Wilbur, Ira Allen, 2:172.

What McLane did or where he was from late January to mid-March is not known. He had earlier told cushing that, after he received his instructions from Genet, he would sail to France and then return to Montreal in the spring via New York. However, it is doubtful whether he could have gone to France at this time since it took, in the 1790's, three weeks for a 
On April 20th, David Mclane was seen by Butterfield at Asa Holgate's tavern in Swanton. Upon their meeting, McLane asked Butterfield if there were "any discoveries respecting him" because "he said he had heard on the road that he had been discovered;" Butterfield answered that he

\section{2 (continued)}

one-way transatlantic crossing. 26 state Trials 721, 767 ; See, Wade, "Quebec and the French Revolution," 360-361 (Meziere's voyage from New York to Brest lasted from october lith to November 2nd).

There were a number of scovel and scovil families living in vermont in 1800, including two in Swanton, but none in nearby st. Albans. In 1790, there were fewer scovels and scovils in vermont in 1790 and none in Swanton or st. Albans. Heads of Families at the second Census of the United States Taken in the Year 1800: Vermont (Montpelier: Vermont Historical Society, 1938), 79-80, 222; Heads of Families at the First Census of the United States Taken in the Year 1790: Vermont (Washington: Government Printing office, 1907; reprint, Baltimore: Genealogical Publishing Company, 1966), 26-27, 90 .

According to Butterfield's pre-trial deposition, it was at saratoga that Mclane indicated that he was working for Adet and had been to Canada to see if the "Canadians were disposed to rise." However, at the trial, Butterfield testified that this conversation occurred the previous November at Swanton. Deposition of Thomas Butterfield, May 22, 1797, Canadian Archives, Series Q, Vol. 79-1, 125, in Brymner, "French Republican Designs on Canada," Note D, 7I; 26 state Trials 721, 771-772. 
had heard nothing. Mclane then proceeded to speak with Asa Holgate. /133/ The next day, Mclane wanted to go to the Isle Ia Motte (in the middle of Lake Champlain) and had Butterfield find two others to assist him, with Butterfield, in rowing a boat across the lake; what McLane did on the island is unknown. Then, on April 26th, McIane inquired of Butterfield if the latter had any business at st. John's and, when told that he did, McLane asked Butterfield to go to st. John's, find Frichet, and bring him back. Butterfield agreed and left by canoe with one "Partlow;" the two returned the following day with Frichet and one other person. /134/ Once Frichet arrived, he and

133 Testimony of Thomas Butterfield, July 7, 1797, in 26 State Trials 721, 772-773; Deposition of Thomas Butterfield, May 22, 1797 , Canadian Archives, Series Q, Vol. 79-1, 125, and the Deposition of Daniel Mclane, September 22, 1797, Canadian Archives, Series Q, Vol. 79-1, 129, both in Brymner, "French Republican Designs on Canada," Note D, 71 and 72, respectively.

13426 State Trials 721, 772; Deposition of Thomas Butterfield, May 22, 1797, Canadian Archives, Series Q, Vol. 79-1, 125, in Brymner, "French Republican Designs on Canada," Note D, 71; Garrett, Atlas of North America, 44.

The person who accompanied Butterfield, Partlow, and Frichet back to Swanton was the servant of "Mr. Ferguson of Missisqui Bay." It is not known what, if any, role he and Partlow played in McLane's plans. Deposition of Thomas Butterfield, May 22, 1797, Canadian Archives, Series Q, Vol. 79-1, 125, in Brymner, "French Republican Designs on Canada," Note D, 71 . 
the Mclane brothers went to st. Albans. There, at Scovil's house, David McLane reminded Frichet of their meeting eight months before, asked whether there was "any news in Canada" and if "he might safely go thither," and then indicated that he wanted Frichet to take him to quebec City. /135/ Mclane would not reveal why he wanted to go into Canada and when Frichet pressed the matter, he was first told that it was none of his business, but McLane eventually said that he was going to buy horses and that "if any one asks my name say it is Jacob Felt." /136/ Despite this obvious lie, Frichet agreed to go. Frichet and David McLane left on April 30th, telling Daniel that they were leaving for the Isle La Motte and that they would be back in two or three weeks; in reality, they headed for the border. /I37/

135 Deposition of Thomas Butterfield, May 22, 1797, Canadian Archives, series 2 , Vol. 79-1, 125, in Brymner, "French Republican Designs on Canada," Note D, 71; Testimony of Charles Frichet, July 7, 1797, in 26 state Trials 721, 774.

136 Deposition of Thomas Butterfield, May 22, 1797, Canadian Archives, Series Q, Vol. 79-1, 125, in Brymner, "French Republican Designs on Canada," Note D, 71; Testimony of Charles Frichet, July 7, 1797, in 26 state Trials $721,774$.

137 Deposition of Daniel McLane, May 22, 1797, Canadian Archives, Series Q, Vol. 79-1, 129, in Brymner, "French Republican Designs on Canada," Note $D, 72$.

When considering the credibility of Daniel Mclane's deposition, it is important to remember that, at the time it was given, he himself was in the custody of the British for suspicion of high treason 
within a few days, McLane and Frichet were at st. Nicholas (about fifteen miles southwest of Quebec City) where McLane revealed to Frichet that he was actually working for the French. /138/ Frichet threatened to leave Mclane, but after assurances that Mclane did not mean to hurt anyone, the two continued towards the city. At twelve or one o'clock on the afternoon of May 10th, just outside Quebec City, Mclane had Frichet go into town to have John Black brought back to him. But, as mentioned earlier, Black was seeking to regain the confidence of both his old customers and the colonial government and McLane's appearance gave him just the opportunity he needed. Black pretended to go along, promised to provide McLane and Frichet safe quarters, and took Mclane's pocketbook (which was full of papers) lest it might fall into the wrong hands, but once Black left Frichet and McLane (who went to his home after it was dark), he went to John Young, a member of the colony's Executive Council, and swore out a

137 (continued)

and, therefore, may not have been willing to volunteer any information implicating himself in his brother's plot. Greenwood, Legacies of Fear, 146; Deposition of Daniel Mclane, May 22, 1797, Canadian Archives, Series Q, Vol. 79-1, 129, in Brymner, "French Republican Designs on Canada," Note D, 72 . Brymner, "French Republican Designs on Canada," Note D, 69-70; Garrett, Atlas of North America, 44. 
deposition against the two. /139/ McLane was arrested that night at about eleven o'clock at Black's house and Frichet shortly afterward in Quebec city. From then on, until McLane's trial, Black was provided with a constant

139 It is possible that this was not Black's first meeting with McLane or other French emissaries. Remember, at McLane's trial, Butterfield testified that he had asked McLane in November, 1796, "if he [McLane] had found any men that could be depended on, who were willing to join him," that McLane answered in the affirmative, and that one of the people McLane named was "one Black or Blake." Furthermore, when Mclane mentioned that he was going to Philadelphia to report to Adet, Butterfield asked if McLane "had any letters to Mr. Adet; he said he had one, which I understood to be from $\mathrm{Mr}$. Black or Blake." Testimony of Thomas Butterfield, July 7, 1797, in 26 State Trials $721,772$.

Butterfield made a similar statement in his pre-trial deposition:

That Examinant [Butterfield] never hear Mclean [sic] mention that any Person in Canada knew his [McLane's] Designs, except one Black or Blake. Deposition of Thomas Butterfield, May 22, 1797, Canadian Archives, Series Q, vol. 79-1, 125, in Brymner, "French Republican Designs on Canada," Note D, 71 .

Even more incriminating statements were made by Frichet. In his pre-trial deposition, Frichet indicated that, just as he and McLane arrived at the outskirts of Quebec City, Mclane asked Frichet if he knew Black; when Frichet said that he did not, McLane stated that "I know him well" and, when Frichet inquired if Mclane had any letter to be given to Black by which to introduce Frichet, McLane replied:

I have none. It is not necessary you will tell him if he is alone that I am here - that it is McLane. Deposition of 
139 (continued)

Charles Frichet, May 12, 1797, Canadian

Archives, Series Q, Vol. 79-1, 13, in

Brymner, "French Republican Designs on

Canada," Note D, 69-70.

[Black, however, testified at

Mclane's trial that he knew Mclane only by the alias of "Jacob Felt" until the latter part of their conversation on May 10th. There is no mention of the alias in Black's deposition, although it does indicate that Black did not know Mclane's name until sometime during their May loth meeting. 26 state Trials 721, 778; Deposition of John Black, May 10, 1797, Canadian Archives, Series Q, Vol. 79-1, 7, in Brymner, "French Republican Designs on Canada," Note D, 67-69.]

In addition, at the trial, Frichet testified that, after he had brought Black to McLane:

Mr. Black then told the prisoner [McLane], that I [Frichet] had informed him [Black] of the intention of his [Mclane's] journey; Mr. Black said he did not think it could succeed, that he had attempted the same business without success, and he therefore advised the prisoner to go off without making the attempt. Testimony of Charles Frichet, July 7, 1797, in 26 state Trials 721, 775.

At the trial, Black (who was the last prosecution witness to testify) did not address any of the testimony which indicated that he may have had prior dealings with Mclane or may have corresponded with Adet. He did admit, however, that Mclane handed him two letters when they met. One of the letters was addressed to Black himself and the other to John Blackwood (who sat on Mclane's jury). Black testified that the correspondance only dealt with business matters concerning timber, staves, and lumber, but he did confirm Frichet's account that he and McLane tore up the letters after Black read them and that they, on Frichet's recommendation, then buried them. The letters were from Captain Hunsden, a Vermont resident who, according to both Black and 
139 (continued)

Mclane, knew Black from some previous occasion. In his pre-trial deposition, Black mentions McLane's distrust for Blackwood as "a Dangerous man to his [McLane's] Cause." After McLane's arrest, Black dug up the letters and delivered them to the court clerk at the trial; unfortunately, the transcript of the trial does not record the text of those documents. 26 State Trials 721, 775, 778-779, 783; Deposition of John Black, May 10, 1797, Canadian Archives, Series Q, vol. 79-1, 7, in Brymner, "French Republican Designs on Canada," Note $D$, 67-69.

None of the above matters were pursued at McLane's trial. If Black did know McLane before May, 1797, then it is difficult to understand why he did not bring up at the trial any of Mclane's earlier activities unless he was a willing accomplice or had failed to advise the colonial authorities of what was going on. See 26 state Trials 721, 776-779.

Mclane's pocketbook and the papers that it contained, and Black's taking of those materials just before McLane's arrest, are mentioned only in Frichet's deposition and were not brought up at the trial. Assuming that Frichet's account is accurate, I was not able to find out what those documents said nor what Black did with them. Deposition of Charles Frichet, May 12, 1797, Canadian Archives, Series $Q$, Vol. 79-1, 13, and the Deposition of John Black, May 10, 1797, Canadian Archives, Series Q, Vol. 79-1, 7, both in Brymner, "French Republican Designs on Canada," Note D, 69-70 and 67-69, respectively; 26 State Trials 721, 773-779. 
bodyguard and, afterward, obtained the grant of the township of Bedford for his services. /140/

But Black was not the only one to go to the authorities. Back in the previous August, immediately after his second encounter with Mclane, Barnard, who had been (probably unbeknownst to McLane) a spy for the British during the American Revolution, went to Thomas McCord, a justice of the peace in Montreal, and told Mccord about

26 State Trials $721,774-775,776,778$;

Deposition of Charles Frichet, May 12, 1797, Canadian Archives, Series Q, Vol. 79-1, 13, and the Deposition of John Black, May 10, 1797, Canadian Archives,

Series Q, Vol. 79-1, 7, both in Brymner, "French Republican Designs on Canada," Note D, 69-70 and 67-69, respectively; Greenwood, Legacies of Fear, 145-146; Peter N. Moogk, "John Young," in Dictionary of Canadian Biography, Vol. 5, 878; Greenwood, "Garrison Mentality," 136, 147; Greenwood, "John Black," DCB, Vol. 5, 84. 
everything that had passed to-date. Mccord, in turn, instructed Barnard to get more information. /141/ When Barnard met McLane again in November, Mclane indicated that, while in Montreal, he had learned that "suspicions were entertained against him" and accused Barnard of betrayal, to which Barnard replied that:

I had mentioned the matter to Mr. Maccord [sic], but had not mentioned his name; he said he was very sorry for it, and that I must be more cautious in [the] future. /142/

McLane also may not have known that, like Barnard, his old acquaintance, Elmer Cushing, was a British spy during the Revolution. /143/ But now, instead of patriotism, Cushing's primary motivation was a desire to reverse his dire economic situation; his tavern was failing and he was contemplating the closure of his business. A few days after meeting Mclane, Cushing went to his lawyer, stephen sewell. During their conversation, Cushing

141 Ivanhoe Caron, La Colonisation de la province de Quebec: Les Cantons de I'Est, 1791-1815 (Quebec: L'Action Sociale, 1927), 182-183; Deposition of William Barnard, December 1, 1796, Canadian Archives, Series Q, Vol. 78, 149, in Brymner, "French Republican Designs on Canada," Note D, 64-65; 26 state Trials $721,764-765$.

142 Deposition of William Barnard, December 1, 1796, Canadian Archives, series Q, Vol. 78, 149, in Brymner, "French Republican Designs on Canada," Note D, 64-65; Testimony of William Barnard, July 7, 1797, in 26 State Trials 721, 765. Caron, Ia Colonisation de la Province de Quebec, $182-183$ 
contradicted Sewell's opinion that the Road Act riots were at $a n$ end and mentioned that he had been approached by a French agent who said that the plans to invade Lower Canada were completed. Sewell, the son of a prominent American loyalist, already believed that the Canadians would rise up and massacre the local British population at the first sign of the French and, when cushing told him the next day that Adet himself had come to Montreal, he readily accepted it and rushed cushing off to Quebec city to talk to his brother, Attorney General Jonathan Sewell. Also present at the meeting were Governor Prescott and Prescott's Civil secretary, Herman Ryland. All three agreed that the information was important enough to grant, as demanded by Cushing, a township of land for himself and his friend, William Barnard, in exchange for their testimony. Prescott, however, would not approve the deal until the Chief Justice of Lower Canada, William Osgoode, had been consulted; after a long conference with Ryland and the Attorney General, Osgoode concurred with the arrangement. $1144 /$

Both Cushing and Barnard gave depositions outlining the details of their meetings with Mclane. In April, 1797,

144 Greenwood, "Garrison Mentality," 136-137; Greenwood, Legacies of Fear, 142-143; Cushing, Appeal, 7-15; F. Murray Greenwood, "Stephen sewell (Sewall)," in DCB, Vol. 6, 700-701. 
wanting to take advantage of his grant as soon as possible, Cushing had his other lawyer, George Francklin, write to Ryland requesting immediate possession, but Ryland responded on May 28 th with the warning that the "approaching Trial of Mr. McLane will probably afford Mr. Cushing an opportunity ... to evince how far he is deserving of the attention and favor of the Government." /145/ At Mclane's trial, Barnard was asked by George Pyke, one of the defense lawyers, if he had received any promises of a township for his testimony; Barnard quickly perjured himself by answering "No" and Chief Justice Osgoode, now acting as the presiding judge at the trial, promptly

145 Greenwood, "Garrison Mentality," 137; Greenwood, "The Treason Trial," 6-7; Ryland to Francklin, May 28, 1797, Prescott Papers, M.G. 23, GII 17, series 1, vol. 9, NAC, quoted in Greenwood, "The Treason Trial," 6 . 
interjected that the "question has been allowed; but I think it was an improper one." /146/ Later on, Pyke asked the same question of Cushing who answered:

I have a promise of a township, but not as a reward for any information which I ever gave against the prisoner. /147/

Both Attorney General Sewell, now serving as the prosecuting attorney, and Francklin, now Pyke's co-counsel, said nothing during either exchange. /148/

There was also an encounter at McLane's trial between Chandonet and Francklin during which it came out that, during the winter of 1796-1797, Chandonet had written to the colonial authorities of his intention to return to his farm in Upper Canada and to take his changes as to any charges that might be brought against him. In fact, he did return and apparently lived there undisturbed until he was

14626 State Trials 721, 765; Comments of Chief Justice William Osgoode, July 7, 1797, in 26 State Trials $721,765$.

147 Testimony of william Cushing, July 7, 1797, in 26 State Trials $721,769$.

Cushing would, for 30 years, deny that he gave his testimony in exchange for a township. According to cushing, the promise of a township was unrelated to the McLane affair, but that it was gratuitously arranged by stephen sewell who, as a friend, was concerned about Cushing's financial well-being. Cushing, Appeal, 7-15, 26-30.

see, also, footnote 111 .

14826 State Trials 721, 769; Greenwood, "The Treason Trial," 6 . 
subpoened to attend the trial. But it came out that, at about the same time that Chandonet wrote his letter, he told the authorities everything he knew about McLane, although he denied that he did so in order to return to his farm. /149/

And finally, Hathaway went to Philadelphia and met with Secretary of state Thomas Pickering on May 8, 1797, and informed him of McLane's plot, showing some documents in Adet's handwriting as well as an estimate of the men, money, and materials needed to carry on an expedition into Canada. Hathaway was on his way to Lower Canada to warn the British when he heard that Mclane had been arrested on May loth and then, for reasons unknown, he was in Boston the following July telling his story to the Governor of Massachusetts. /150/ 
CHAPTER VII

MCLANE'S INTELLIGENCE GATHERING AND MILITARY EFFORTS

The recruitment of fellow agents was not Mclane's only task. As already noted, he went into canada on three occasions; first, in August through october, 1796, then in November, 1796, and, finally, in April through May, 1797. Furthermore, when he was in Philadelphia in the winter of 1796-1797, he received two payments from Adet for which there were entries indicating the purposes of Mclane's trips; the first, dated December 27 th, indicates that Mclane had been previously hired to obtain intelligence about Canada and the second, logged one month later, states that McLane had been entrusted with a future, but unspecified, mission. /151/

We do not know what McLane told Holgate, but from the pre-trial statements and the testimony of the others that he contacted, we can get an idea of what intelligence McLane was to procure and what his secret mission was as

151 Greenwood, Legacies of Fear, 141; L.O.C., France, Archives des Affiares etrangeres, Correspondance politique, Etats-Unis, Supp., Vol. 19, no page numbers cited in (and presumably translated by) Greenwood, "The Treason Trial," 2n2. 
well as some detail of how the French planned to incite a rebeliion in Canada and support it with a military invasion.

The recruitment of sympathizers and the gathering of intelligence about the disposition of the canadians were apparently McLane's sole purpose during his first foray into Canada. When he met Butterfield in April, 1796, all that the two supposedly talked about were canals and land with the only hint of what Mclane was up to being his comment that he was heading towards Canada. Two months later, when McLane met Barnard, the only thing McLane told Barnard was that it was his job to "bring about a revolution in Canada" and then he asked Barnard to lead the project. And when he went to st. Johns to solicit Frichet's help, Mclane asked Frichet to go to Philadelphia to meet Adet and to secure for McLane certificates from five or six Canadians to show that the Canadian population was dissatisfied with British rule and wished to be reunited with France. After meeting Barnard and Frichet in July and August, 1796, Mclane stayed in Montreal for two months before leaving for Philadelphia in october. Shortly before his arrest in 1797, McLane bragged to John Black of calming the canadians during this time and putting the Road Act riots to rest; he also used this time, as he told 
Butterfield in November, 1796, to see if the Canadians would rise up against the British. /152/

on his second trip to Canada, Mclane was gathering intelligence, but he was also now in possession of, or at least was now open about having, some very specific plans concerning an invasion of Lower Canada and was talking about those plans when trying to find sympathizers who would participate in the overthrow of the British. Immediately after his return to Montreal, Mclane made a survey of the military advantages of possessing the mountain that overlooks the city. /153/ on that same day, November 5th, he met Cushing, saying that the mountain:

commanded the greatest prospect he ever saw, and might be made a place of great command over Montreal, in case of a war. /154/

Mclane also revealed to cushing that he was working for Adet and informed him that France intended to regain

15226 State Trials 721, 764, 771, 774; Deposition of Thomas Butterfield, May 22, 1797, Canadian Archives, Series Q, Vol. 79-1, 125, Deposition of William Barnard, December 1, 1796, Canadian Archives, Series Q, Vol. 78, 149, Deposition of Charles Frichet, May 12, 1797, Canadian Archives, Series Q, Vol. 79-1, 13, and the Deposition of John Black, May 10, 1797, Canadian Archives, Series Q, Vol. 79-1, 7, all in Brymner, "French Republican Designs on Canada," Note $D, 71,64-65,69-70$, and 67-69 respectively; Greenwood, "The Treason Trial," $2 \mathrm{n} 2$.

154 Testimony of Elmer Cushing on July 7, 1797, in 26 State Trials $721,766$. 
Canada either by force or treaty. Furthermore, he told him that there would be a French naval invasion of the colony the following spring that would bring ten to fifteen thousand troops and that Montreal and Quebec city were to be attacked simultaneously. The first objectives of the assault were the seizure of the money and valuable property in the cities to defray France's costs of the invasion and then the confinement of the priests and leading citizens of the province; the safety and property of those who supported the French would be protected, but it "would fare hard" for those who opposed it. Mclane himself would, before the attack, be in Quebec city with a number of others, after getting the men into Lower Canada by rafts or any other means he could, in order to arouse discontent and mutinies, as well as to spike the cannons, with the city's garrison. /155/ In addition, McLane would personally lead the attack on Montreal and he claimed to have had:

many people near the Iines in the states, who had already engaged to furnish him [McLane] with a number of men each, who were to come in and assist in the attack against Montreal. /156/ 
When cushing refused to assist McLane in carrying out these plans, McLane asked him to at least use his influence to keep the Canadians quiet until spring:

$$
\begin{aligned}
& \text { for these disturbances on account of the road } \\
& \text { act, are very detrimental to the cause. /157/ }
\end{aligned}
$$

Finally, Mclane told Cushing that he did not need any assistance from the Canadians themselves until "the first blow was struck," but that until cushing agreed to join the plot, he could not divulge any more information. /158/

When Mclane met Barnard for the third time a few days later, he told Barnard that an army would be in Montreal the following spring and, just as he told cushing, the objective was to seize all the money in the city and to confine its leading citizens, but he added that it was to be done with as little bloodshed as possible. McLane also told Barnard that he wanted him to find out how much money the local seminary had and where it was kept, to make a similar survey as to the assets of Montreal's principal merchants, and to sound the local populace to find out who 
would support and oppose a revolt. Finally, Barnard was, like Cushing, to use his influence to keep the Canadians quiet until spring. /159/

When McLane met Butterfield again, the latter agreed to join the conspiracy and he "did certainly engage to assist him [McLane] in the undertaking," but exactly what, if anything, Butterfield did at this time is unknown. We do know that, during this meeting, Mclane told Butterfield that a rebellion by the Canadians would be assisted by a French fleet that was to arrive in the summer of 1797; the two also spoke about the seizure of Quebec city, although the details of that conversation are not known, and Mclane mentioned to Butterfield the idea of bringing men from the United states into Canada by rafts. /160/ Indeed, when Mclane spoke with Chandonet (probably during their winter meeting), the details of how to

15926 State Trials 721, 764-765; Deposition of William Barnard, December 1, 1796, Canadian Archives, Series Q, Vol. 78, 149, in Brymner, "French Republican Designs on Canada," Note D, 64-65.

Testimony of Thomas Butterfield on July 7, 1797, in 26 state Trials 721, 772; 26 state Trials 721, 771-773; Deposition of Thomas Butterfield, May 22, 1797, Canadian Archives, Series Q, Vol. 79-1, 125, in Brymner, "French Republican Designs on Canada," Note $D, 71$. 
transport the men by rafts seemed to be all worked out. McLane began the conversation by telling Chandonet that he was employed by the French to go into Canada to find out how the canadians felt about the colonial government and then he pointed out that st. Regis, New York, where Chandonet was going to live, was just a few leagues upriver on the st. Lawrence from Montreal and, as such, it was a very favorable place to have an ally in light of the logistics of the planned invasion. In particular, McLane said that arms and ammunition were to be brought into Lower Canada in the spring of 1797 hidden on two fleets of rafts, one that would sail down the st. Lawrence River and the other north through Lake Champlain. In addition, another shipment would be concealed on rafts made on the Chateauquay River, thereby fooling everyone into thinking that they were coming from Upper canada. /161/ Furthermore, Mclane said that he had a brother who was coming to the border with a large quantity of dry goods that:

were for the purpose of collecting a store of provisions to be ready when the insurrection in Canada should take place, and that it would 
furnish a good excuse for him [McLane] to be backwards and forwards, as he could visit his brother's store without being suspected. /162/

Finally, in mid-November, 1796, when McLane met with Hathaway, the latter agreed to be the junta's treasurer and was told that Mclane would take Quebec City by surprise; once that was accomplished, a French fleet would sail up the st. Lawrence, troops from Vermont would march into the colony, and McLane would become governor. /163/

As to his third and final trip into Canada, it should first be noted that, although not recorded in the transcript of the trial, a contemporary account of the proceedings states that after Mclane was convicted and sentenced to death, he confessed that he was employed by Adet to deliver correspondence to "some disaffected gentlemen" and that these potential revolutionaries were to be incited into revolt and promised assistance in the form of a naval invasion, though it is not clear from the account whether Mclane was to do this himself or if that in 26 state Trials $721,770$.

It is not clear from Chandonet's testimony whether McIane meant his brother, Daniel, his half-brother, Jacob Felt, or his other brothers. see footnotes 70 and 71 . 
was the intent of the letters. Furthermore, McLane confessed that he was given military commissions that were to be handed out to those who were to lead the rebellion. /164/ However, Mclane's mission at this time may have also included completing the final preparations for, if not the actual, seizure of the garrison at quebec city.

When he left for Quebec City with Frichet, Mclane indicated to Butterfield that he wanted to inspect the fortress there in order to formulate a plan for its seizure. /165/ And then, just as they reached st. Nicholas, McLane allegedly told Frichet that:

you dont [sic] yet know me, I am sent by the French Government to excite an Insurrection in Canada to deliver your Brothers and Relations from Slavery. I am the second in command of the French Army destined to act against this Province. I wish to form a Body of Canadians to Surprize the garrison of Quebec, you can speak to your Brothers \& Relations and perhaps induce them to join us. To surprize the Garrison of Quebec is an easy thing if the Canadians will but unite with me. I want but Five Hundred who would be resolute and secret. /166/

[Anonymous], The Trial, Condemnation and Horrid Execution of David M'Lean, 11 .

The letters may have been those addressed to John Black and John Blackwood. See footnote 139.

166 Deposition of Charles Frichet, May 12, 1797, Canadian Archives, Series Q, Vol. 79-1, 13, in Brymner, "French Republican Designs on Canada," Note $D, 69-70$. 
After Frichet remarked that, even if Mclane were able to seize the fort, he could not hold it, Mclane replied that:

You are mistaken, there are Ten Thousand men now in America, who are ready to join us whenever we begin, upon the first Requisition. /167/

And, on May 10, 1797, when McLane met Black, McLane revealed that the mission which Adet had entrusted to him was the seizure of the garrison at Quebec City. According to McLane, both the French and spanish ministers to the United states were in on the plot and that:

measures were so concerted with $\mathrm{Mr}$. Adet, that if we could but possess ourselves of the garrison by surprise, it could never be recovered from us; for, said he [McLane], besides the measures taken by the French and Spanish ministers, I have fifteen thousand men at the Lines ready at a nod. /168/

Ibid.

Despite McLane's request, Frichet refused to speak to others about joining McLane's plan. Ibid.

168 Testimony of John Black on July 7, 1797, in 26 State Trials $721,777$.

It is interesting to note that Hathaway also believed that the Spanish minister was cooperating with Adet in the latter's attempt to seize canada. No other indication was found, however, in the preparation of this paper to indicate that the Spanish were involved. Wilbur, Ira Allen, 2:172. 
What Mclane wanted in Quebec City was about ten individuals with influence amongst the Canadians who were to be approached one-by-one but would not be informed of McLane's plans until the last moment when they would, under plausible pretenses, raise as many followers as possible. At the appointed time, this force would be joined by others who would arrive from the United States under various pretexts and, then, all of them would be armed by McLane with eight foot pikes (eighteen inches longer then what McLane thought was the combined length of a British musket and bayonet), hardened "in the fire" and pointed with iron, so that when the town gates opened, two companies of men would simultaneously rush the gates and attack the garrison and, hopefully, the English troops would be so surprised that the fort would be taken with little bloodshed. To facilitate the plan, McLane asked Black, whom he believed was friendly with the soldiers, to serve the sentries with a liquor spiked with a lincture of opium known as laudanum. /169/ McLane knew that the

169 Deposition of Charles Frichet, May 12, 1797, Canadian Archives, Series Q, Vol. 79-1, 13, in Brymner, "French Republican Designs on Canada," Note $D, 69-70$.

See footnote 170 regarding the credibility of Frichet's and Black's account of McLane's plan to seize the fort at Quebec city. 
60th Regiment had left the fort at Quebec City that very morning and he believed that more troops might follow before replacements would arrive from Montreal. McLane also felt that the Canadian volunteers in the local militia would offer little resistance and he claimed to have 15,000 men inside the United states who would, once the fort was taken, cross the border and man the installation. /170/ Finally, Black was told that Adet, who had left for France the previous April, was procuring an army that would be sent to Canada to support Mclane and his troops and, to help pay for the cost of seizing Quebec, Mclane wanted to know how much British property, both tangible and

170 Professor Greenwood doubts that, after the capture of the olive Branch, 15,000 men would have been available to Mclane and his accomplices. He does recognize, however, that Frichet and Black may have misconstrued McLane's remarks or may have dramatized or distorted them for their own reasons. For example, Frichet was still in custody for treason and his story may have been induced by a desire to escape McLane's fate. Greenwood, Legacies of Fear, $140,145,302$ n16; 26 state Trials 721, 806 .

See, also, footnote 110 .

Furthermore, Professor Greenwood points out that, no matter how many men McLane had, the confusion resulting from an attack on the garrison at Quebec city could have made a coordinated French naval invasion of the colony a success. Greenwood, Legacies of Fear, 140 . 
intangible, was in the city; Black valued the property at between three and five hundred thousand pounds. /171/ However, if this accurately reflects the mission that Adet entrusted to Mclane the previous January, then it was possibly doomed from the start; as already mentioned, the French Directory gave up the idea of invading Lower Canada when Ira Allen and the olive Branch were captured in october, 1796, but failed to notify Adet, and when he returned to France in May, 1797, he was unable to convince Paris to implement his plan. /172/ In any case, it all came to an end with McLane's arrest on May 10th.

171 Deposition of John Black, May 10, 1797, Canadian Archives, Series Q, Vol. 79-1, 13, in Brymner, "French Republican Designs on Canada," Note D, 69-70. Greenwood, "Garrison Mentality," 35, 36n27, 44-45. 
CHAPTER VIII

MCLANE'S ARREST, ATTEMPTED RESCUE, AND THE COURT THAT TRIED HIM

Late at night on May 10, 1797, just before McLane's arrest, Black's deposition was delivered to Herman Ryland, the Civil Secretary to Governor Prescott. Ryland immediately went to Prescott and, on his orders, took a small detachment of soldiers to Black's house where they found McLane asleep in bed. Ryland awoke McLane and asked for his name, to which McLane replied "Felt." When Ryland said that he understood it was "McLane," he was again told that it was "Felt" and that he was mistaken. McLane was then taken into custody and brought to the "mainguard" where Ryland asked his prisoner if he had any cash on this possession; in response, McLane turned over a bag containing $\$ 140$, most of it in quarters. When asked what name should be placed on the receipt for the money, McLane answered "Jacob Felt." Throughout all of this, Mclane was calm and collected. /173/

On May I0th, as Frichet was taking Black to meet Mclane, Frichet noted that he had seen McLane: 
News of the arrest quickly reached vermont. On about May 18th, after speaking with Francis Chandonet (who, by now, had communicated everything that he knew about David McLane to the British) and Henri Meziere's old agent (and English spy), Jacques Rous, Daniel McLane assumed the alias of "Joseph Worthington" and, with Thomas Butterfield, went to st. Johns where they were almost immediately arrested by the British (who may have been warned by Chandonet and/or Rous) and placed into custody under the Better Preservation Act for suspicion of treason. Brought to Montreal, Butterfield and Daniel McLane both signed voluntary depositions on May 22 nd which confirmed much of the information that the government had already collected against Daniel's brother, David McLane. /174/

\section{3 (continued)}

so liberal in dispensing his money that he [Frichet] put him [McLane] on his guard as it might expose him. Deposition of John Black, May 10, 1797, Canadian Archives, Series $Q$, vol. $79-1,7$, in Brymner, "French Republican Designs on Canada," Note D, 67-69.

174 Deposition of Thomas Butterfield, May 22, 1797, Canadian Archives, Series Q, Vol. 79-1, 125, and Deposition of Daniel McLane, May 22, 1797, Canadian Archives, Series Q, Vol 79-1, 125, both in Brymner, "French Republican Designs on Canada," Note D, 71 and 72, respectively; Greenwood, Legacies of Fear, 146.

According to his deposition, Butterfield went to st. Johns only to sell lumber and to purchase salt and "Worthington," who told him that he was going on to Montreal and possibly Quebec city, just happened to accompany him. Furthermore, while "worthington" 
Shortly afterward, rumors began to spread that David McLane had really intended a bloody, rather than a bloodless, revolution. As early as May 29th, accounts were made that, if successful, Mclane would have massacred all of the civilian leaders and military officers found in Quebec City and, by late June, these rumors were widely-accepted by the British community. Although not supported by evidence, this belief was expressed in much of the correspondance between colonial officials, was exploited at McLane's trial, and was regarded as fact by the English elite long after McLane was hanged. /175/

174 (continued)

never told Butterfield that he was David McLane's brother, Butterfield said that he suspected as much after overhearing a discussion between "Worthington," Chandonet, and Rous. Deposition of Thomas Butterfield, May 22, 1797, Canadian Archives, Series Q, Vol. 79-1, 125, in Brymner, "French Republican Designs on Canada," Note D, 71 .

In contrast, Daniel Mclane stated in his deposition that he came into Canada to get information regarding his brother, to find out why he was arrested, and to see if it was possible to obtain his release. In addition, he used an alias in order to avoid any connection with his brother that might arouse suspicion and possible detention. Also, the deposition states that Daniel Mclane hired Butterfield as a guide to take him to Montreal since he, himself, had never been in Lower Canada. However, the deposition does not indicate when Daniel Mclane decided to use his alias nor whether he ever told Butterfield his real name. Deposition of Daniel Mclane, May 22, 1797, Canadian Archives, Series Q, Vol. 79-1, 129, in Brymner, "French Republican Designs on Canada," Note D, 72 . 
Also after McLane's arrest, the colonial officials and other leading members of the British community were convinced that a French armada would invade Lower Canada that spring or summer. Furthermore, even if such an attack was not planned, the English colonists were becoming increasingly horrified at the prospect that, with Austria withdrawing from the alliance against France, the French Directory might invade Britain itself. Governor Prescott would write that "the spirit of the Times [is] calling forcibly for an immediate Example" to dissuade potential spies and traitors, but what opportunity was there? He could go after the three Canadians (Bizette and the Provencals) who were arrested in February and March but, by the time of Mclane's arrest, had not yet been tried. The period of time in which criminal cases could be heard at the court's biannual sessions (March and September) were limited to ten days, but the law required that, in cases of treason, copies of the indictment and other documents must be presented to the defendant ten days before trial. The grand jury in March, however, did not issue their indictment against the three until only five days before the end of the court's spring term and, therefore, Bizette and the Provencals could not be brought to trial. If he wished, Prescott could have issued a commission for a special court to hear the case in advance of the court's next regularly scheduled session in 
September, but he was not willing to risk a rebellion in doing so. /176/

176 Greenwood, Legacies of Fear, 147, 156; Prescott to Portland, May 27, 1797, PAC, CO 42, v.109:40, quoted in Greenwood, "Garrison Mentality," 142; Greenwood, "The Treason Trial," 3; Quebec Gazette, 23 March 1797; Report of Attorney General Sewell, Canadian Archives, Series Q, Vol. 79-1, 19, and Attorney General Sewell's Calendar, Canadian Archives, Series 2, Vol. 79-1, 30, both in Brymner, "French Republican Designs on Canada," Note D, 73-76 and $76-78$, respectively.

The decision not to make an example out of Bizette and the Provincals was fortunate because, when they finally went to trial in september, 1797, they were acquitted. Quebec Gazette, 14 september 1797.

As to the requirement that a copy of an indictment for treason must be presented to the defendant ten days before arraignment, it should be remembered that, ever since 1764, the criminal law of England was applied in Canada subject to whatever alterations and amendments were adopted by the colonial authorities. [Maseres] to Hillsborough, "A DRAUGHT of An Intended Report of the Honourable the Governor in Chief and the Council of the Province of Quebec to the King's most Excellent Majesty in his Privy Council; concerning The state of the Laws and the Administration of Justice in that Province," February 27, 1769, and The Quebec Act, 14 Geo. III, C. 83, s. 11 , both in Adam Shortt and Arthur G. Doughty, eds., Canadian Archives: Documents Relating to the Constitutional History of Canada, 1759-1791, Part 1 , Second and Revised Edition (Ottawa: J. de L. Tache, Printer to the King's Most Excellent Majesty, 1918), 328 and 574 respectively.

At the time of McLane's trial, British legal procedure for a treason trial included a number of safeguards, most of which were adopted as part of the Treason Act of 1695 to avoid the miscarriages of justice that were perceived to have taken place before the Glorious Revolution. Among the 
176 (continued)

protections that are pertinent to Mclane's trial are:

1) The defendant was to be provided a copy of the indictment in the presence of two witnesses ten days before their trial.

2) A copy of the jury panel and of a list of the prosecution's witnesses, including their names, professions, and places of abode, were to be delivered to the defendant at the same time as the copy of the indictment.

3) The defendant would be able to compel the attendance of their own witnesses.

4) The defendant would be entitled to have a lawyer present his defense on his behalf and to have two attorneys appointed for that purpose.

5) The defendant would be entitled to 35 peremptory challenges instead of the 20 allowed in a normal felony trial.

6) No evidence of any overt act that was not expressly laid out in the indictment would be admitted or given.

7) No one, unless they confess, refuse to plead, or challenge preemptorily more than 35 members of the jury panel, could be indicted, tried, or convicted except upon the testimony of two witnesses who either testify to the same overt act or to separate acts to the same treason (e.g., one testifies to the stealing of military secrets and the other to the selling of those secrets). J.P. Wallis, "Treason and Treason Felony," in Encyclopaedia of the Laws of England, Vol. 12, ed. A. Wood Renton, (London: Sweet and Maxwell, 1898), 262-263. 
McLane, on the other hand, was perfect for Prescott's purposes because he was not only a foreigner, but an American, and the distrust and dislike in canada of the United States was still strong. /177/ Therefore, upon the advice of Chief Justice osgoode, Prescott issued a Special Commission of Oyer and Terminer on May 24, 1797, which empowered:

the justices thereby assigned, or any three of them . . . to inquire, hear, and determine all high treasons and misprisons of high treason, committed within the district of Quebec. /178/

Assigned to this special court were fourteen of the fifteen members of the colony's Executive Council; Anglican Bishop Jacob Mountain was the sole exception. /179/

177 Greenwood, Legacies of Fear, 147; Greenwood, "The Treason Trial," 3; Tetu, "Quebec and the French Revolution," 4; Kennedy, Archives of Canada, August 11, 1993, Unrecorded telephone interview by Mark Thorburn.

26 State Trials 721, 721; Quebec Gazette, 25 May 1797.

17926 State Trials 721, 721; Greenwood, Legacies of Fear, 148 .

To understand the uniqueness of this court and of the men appointed to its bench, a brief explanation of the colony's Executive Council and of the legal institutions of Lower Canada in 1797 is required.

By royal command, an Executive Council was established in 1791, essentially consisting of the judicial and political leaders of the province, to 
179 (continued)

assist the Governor of Lower Canada in his administration of the colony's government. George R[ex] to Dorchester, section 4, september 16 , 1791, Canadian Archives, G.181, pg. 1 et. seq., quoted in "Instructions to Lord Dorchester as Governor of Lower Canada" found in Arthur G. Doughty and Duncan A. McArthur, eds., Public Archives: Documents Relating to the Constitutional History of Canada, 1791-1818 (ottawa: C.H. Parmelee, Printer to the King's Most Excellent Majesty, 1914), 14.

As to the legal system, when civilian government was restored to Canada in 1774, it was agreed that while French law would govern the civil rights and responsibilities of the colony's inhabitants, British law would continue to govern criminal affairs as it had for almost a decade. Jeffers, History of Canada, 39; [Maseres] to Hillsborough, "A DRAUGHT of An Intended Report," February 27, 1769, and The Quebec Act, 14 Geo. III, c. $83, \mathrm{~s} .11$, both in shortt and Doughty, Canadian Archives: Documents Relating to the Constitutional History of Canada, 1759-1791, Part 1, 328 and 574 respectively.

Under the Judicature Act of 1794, which entirely reorganized the courts in Lower Canada, the colony was divided into three judicial districts: Quebec, Montreal, and Three Rivers (now Trois Rivieres). A "Court of King's Bench," which had original jurisdiction in all civil and criminal cases as well as in those (except admiralty) where the king was a party, was established for the districts of Quebec and Montreal. Each of these courts consisted of a chief justice (the Chief Justice of Lower Canada in Quebec, the Chief Justice "of the said court" in Montreal) and three associate judges. In these courts, all criminal trials were presided over by two or more judges, one of whom had to be one of the chief justices. Criminal trials in both Quebec and Montreal were conducted twice a year; in March and in september. Three Rivers also had its own court of King's Bench that heard criminal cases twice a year and consisted of two judges from the King's Bench of either Montreal or Quebec as well as the Provincial Judge for Three Rivers. There were also various inferior civil courts to hear minor cases. "An Act for the division of the Province of Lower-Canada, for amending the Judicature thereof, and for repealing certain laws herein 
William Osgoode and James Monk, both chief justices of the King's Bench and members of the Executive Council, were named in the special Commission as "of the quorum." /180/

179 (continued)

mentioned", The Provincial statutes of Lower Canada, $34 \mathrm{Geo}$. III, c. 6 , sections 1-3, 11, 14-21, p. 1:77$81,1: 85-87$, 1:89-110; George $R[\mathrm{ex}]$ to Dorchester, Section 22, september 16, 1791, quoted in "Instructions to Lord Dorchester as Governor of Lower Canada" in Doughty and McArthur, Public Archives: Documents Relating to the Constitutional History of Canada, 1791-1818, 20, 125-127, 130-131, 132-134.

However, the Judicature Act also provided that:

nothing in this Act contained shall

extend or be construed to extend, to prevent the Governor, Lieutenant-Governor or Person administering the Government of this Province. . . from issuing at any time or times, other than during the sittings of the said Terms, Commissions of oyer and Terminer and General Gaol Delivery, for such district and county within this Province, as shall be deemed expedient and necessary. "An Act - . for amending the Judicature," The Provincial statutes of Lower Canada, 34 Geo. III, c. 6 , section 4, p. 81 .

A Commission of oyer and Terminer was a direction to a group of judges, who were named in the commission, to try criminal cases. A commission to try special or specific cases was known as a special Commission. Riddell, "Canadian state Trials," 329n8; Henry Campbell Black and others, Black's Law Dictionary: Definitions of the Terms and Phrases of American and English Jurisprudence, Ancient and Modern, Sixth Edition (St. Paul: West Publishing Company, 1990), 1106-1107. 26 State Trials $721,721$.

Anyone might be named to the court established by a commission of oyer and Terminer, but the court 
Five of the fourteen who were assigned to the McLane court were judges sitting on the King's Bench in either Montreal or Quebec City; the other nine were a combination of merchants, politicians, and retired judges of whom only five participated in the trial. /181/ The five judges were:

William Osgoode (1754-1824), the Chief Justice of Lower Canada. Educated in oxford and admitted to the bar in 1779, he had enough influence within the British government to be named Chief Justice of Upper Canada in 1791 without any prior courtroom experience as either a lawyer or as a judge. In 1794, he became chief Justice of Lower Canada and was, by the time of McLane's trial, Governor Prescott's principal advisor. In addition, Osgoode was extremely hostile towards the Americans and believed that Adet orchestrated the Road Act riots in 1796, /182/

James Monk (1745-1826), Chief Justice of the King's Bench at Montreal. Admitted to the bar in 1768 and appointed Solicitor General of Nova Scotia in 1772, he was named Attorney General of Quebec four years later and served at that post until 1789. Becoming Attorney General of Lower Canada in 1792, he

180 (continued)

could not act without the presence of at least one person from the group of individuals who were "of the quorum." Also, those who were not "of the quorum" were, as a rule, not expected to interfere with the proceedings of the trial. Riddell, "Canadian State Trials," 329n8.

182 S.R. Mealing, "William Osgoode," in Dictionary of Canadian Biography, Vol. 6, 557-559; Greenwood, "The Treason Trial," 5; Greenwood, Legacies of Fear, 148 . 
investigated the Militia Act riots two years later and decided that they were the work of French and American subversives; as a result of his conclusions, Monk took several measures to counter the development of any Canadian resistance to British authority, including the arrest of 50 to 100 Canadians and the enactment of legislation that forbid the unauthorized entry, and allowed the summary deportation, of aliens as well as suspend habeas corpus whenever treason was suspected. Monk also initiated the

"Associations" that promoted loyalty to the crown. In 1794, he was named Chief Justice at Montreal and, in the year before McLane's trial, practiced "alarmist loyalism," /183/

Thomas Dunn (1729-1818), a judge for the Court of King's Bench in Quebec. A merchant with no legal training, he served as king's attorney in succession matters (1763-1769) and then as a judge of the court of common Pleas (1777-1794) until he became a judge on the King's Bench in 1794. Once very popular with, and supportive of, the Canadians, the early years of the French Revolutionary wars brought him to believe that Lower Canada faced a potential security problem, /184/

Jenkin williams (c.1734-1819), a judge for the court of King's Bench in Quebec. A lawyer before 1767, he began to hold a series of judicial positions in Quebec in 1768, eventually becoming Solicitor General in 1782, a judge on the court of Common Pleas in 1792, and a judge on the King's Bench in 1794. He had a reputation of being a very competent and impartial jurist and his

183 James H. Lambert, "Sir James Monk," DCB, Vol. 6, 511-512; Greenwood, Legacies of Fear, 148 .

184 Pierre Tousignant and Jean-Pierre Wallot, "Thomas Dunn," in DCB, Vol. 5, 287, 289, 291; Riddell, "Canadian State Trials," 330n9; Greenwood, Legacies of Fear, 148. 
decisions, while not showing any bias, often pleased the Canadians. /185/ Unfortunately for McLane, and perhaps because Williams could see the writing on the wall, williams did not attend McLane's trial, /186/

and

Pierre-Amable De Bonne (1758-1816), a judge on the court of King's Bench in Quebec. The nephew of an early French governor of Quebec, De Bonne was a prisoner of the Americans for part of the Revolutionary War and became a lawyer in 1780. He was elected to the Lower Canadian House of Assembly in 1792 and was named to the King's Bench two years later, simultaneously serving in both positions until 1810. However, De Bonne was primarily a politician and, although a Canadian, he was the leader of the French-speaking supporters in the legislature of the colonial government and felt that Adet was responsible for the Road Act riots. /187/

The five other members of the Executive Council who participated in the court's proceedings were:

Francois Baby $(1733-1820)$, a Canadian businessman and seigneur who had, by the late 1770's, become a loyal supporter of the British colonial government. An appointed member of Quebec's Legislative Council (1778-1791), he was also one of the most 862-864; Riddell, "Canadian state Trials," 330n9.

Williams was not "of the quorum" and, therefore, was expected not to interfere with the court's proceedings. See footnote 180 .

187 Pierre Tousignant and Jean-Pierre Wallot, "Pierre-Amable De Bonne," DCB, Vol. 5, 230, 233-234; Riddell, "Canadian State Trials," 330n9; Greenwood, Legacies of Fear, 148. 
trusted officers in the Canadian militia, was a founding member of one of James Monk's associations, and played a large role in the movement in the 1790's to promote loyalty to the Crown, /188/

Hugh Finlay (c.1730-1801), a merchant and seigneur who was an early spokesman for the British business community in the colony. He continuously served on the various executive and legislative bodies of Quebec and Lower Canada since 1765 and was, since 1774, the Deputy Postmaster General for all of British North America. Finlay was also a leader for judicial reform in Quebec during the 1780's, but in the 1790's, he was worried about the exploitation of the Canadians by demagogues, /189/

Antoine Juchereau Duchesnay (1740-1806). originally an officer in the French colonial forces, he joined the British military after the cession of Canada in 1763. After 1772, he primarily occupied himself as a seignuer and built up an extremely large fortune. He also spent 18 months as a prisoner of the Americans during the early part of the Revolution and, in 1792, was elected to the Lower Canadian House of Assembly, but essentially retired from public life two years later, /190/

Joseph-Dominique-Emmanuel Le Moyne de Longueuil, the third Baron of Longueuil (17381807), was a career officer who served in the French military before the cession of Canada and, later, in the British army. Taken prisoner by the Americans during the war for

John Clarke, "Francois Baby," DCB, Vol. 5, 41-45; "Instructions to Lord Dorchester as Governor of Lower Canada" in Doughty and McArthur, Public Archives: Documents Relating to the Constitutional History of Canada, 1791-1818, 14n4.

I.K. Steele, "Hugh Finlay," in DCB, Vol. 5, 314-319; Greenwood, Legacies of Fear, 148 .

Real Brisson, "Antoine Juchereau Duchesnay," DCB, Vol. 5, 462-464. 
Independence in 1775, he was released two years later and became an inspector-general and, in 1796, a full colonel in the Regiment of Royal Canadians. Also, he was a seigneur and received a good deal of government patronage, /191/

and

John Young (c.1759-1819), merchant and seigneur, he emigrated from London to Quebec city in 1783 and quickly became a spokesman for the community's English business establishment. He rapidly advanced in politics, was elected to the Lower Canadian House of Assembly in 1792, and became a leader of the English party in both Quebec City and the legislature. In addition, Young approved of the loyalty declarations of the early 1790 's to defend the British Empire from revolution and, like many, interpreted the resistance of the Canadians to a standing militia as a prelude to an uprising and believed that Adet was behind the Road Act riots of 1796. Finally, he was one of the few who testified to John Black's loyalty when the rest of the English community turned its back on him and it was Young that Black went to (and gave his deposition to) to announce McLane's presence in Quebec City. /192/

The remaining four members of the Executive council who took no part in Mclane's trial were:

John Lees (c.1740-1807), merchant, land speculator, seigneur, and militia officer who

191 Le R.P.L. Le Jeune, Dictionnaire General de Biographie, Histoire, Litterature, Agriculture, Commerce, Industrie et des Arts, Sciences, Moeurs, Coutumes, Institutions Politiques et Religieuses du Canada, Vol. 2 (Ottawa: Universite d'ottawa, 1931), 166; Greenwood, Legacies of Fear, 148.

192 Peter N. Moogk, "John Young," in DCB, Vol. 5, 877-878; Greenwood, Legacies of Fear, 148 . 
was elected, in 1792, to the Lower Canadian House of Assembly and was a member of Monk's Association, /193/

James MCGill (1744-1813). A merchant in Montreal who allowed his home to serve as a rendezvous for loyalists during the American occupation (1775-1776) of the city, he held a variety of government appointments since 1776, denounced the Militia Act riots in 1794, and found himself in legal difficulties after Detroit was transferred to the United states in 1796 because of land claims he held in that area, /194/

Pierre (Pierre-Meru) Panet (1731-1804), a Frechman who emigrated to Quebec in 1746 . He approved of the British colonial authorities and demonstrated unwavering loyalty ever since the colony's conquest by England in 1760. Panet became a lawyer in 1768 and a judge on the court of Common Pleas two years later, but resigned from the bench in 1791. Although retired, he remained active in Lower Canada's political affairs, /195/

\section{and}

Paul-Roch de Saint Ours (1747-1814), an officer in the French, and then, after the cession of Canada, the English armies until 1774, he was also a seigneur who was highly favored with government patronage. saint ours was appointed to Quebec's Legislative Council in 1777 and was elected to the Lower Canadian House of Assembly fifteen years later. /196/

Yves Frenette, "John Lees," DCB, Vol. 5, 483-485.

194 J.I. Cooper, "James MCGill," DCB, Vol. 5, 527-528.

195 Raymond Dumais, "Pierre (Pierre-Meru) Panet," DCB, Vol. 5, 652-653.

196 Gaston Deschenes, ed., Dictionnaire des parlementaires du Quebec: 1792-1992 (Sainte-Foy, Quebec: Les Presses de L'Universite Laval, 1993), 679 ; Greenwood, Iegacies of Fear, 148. 
on May 26, 1797, two days after Prescott issued his special commission, the precept instructing the sheriff to convene a grand jury on June 12th was signed by Chief Justice Osgoode and Judges De Bonne, Dunn, and williams. On the 12th, the court met at the courthouse in Quebec City; present were Chief Justice Osgoode, Judge De Bonne, Judge Dunn, Finlay, Baby, Longueuil, Juchereau Duchesnay, and Young. Immediately after Governor Prescott's Special Commission was read, the sheriff brought forward twenty-two men who were sworn in as members of the grand jury. /197/

A precept is an order from a person or group of persons in authority to a peace officer to do some act within the scope of their powers; e.g., an order by a judge to bring a defendant or a witness before the court. Black's Law Dictionary, Sixth Edition, 1176.

A precept from a special commission of oyer and Terminer to a sheriff to call a grand jury must be signed by three or more of the judges named in the commission and at least one of three must be "of the quorum." At McLane's trial, Chief Justices Osgoode and Monk were "of the quorum." Riddell, "Canadian state Trials," 330n10; 26 state Trials 721, 721.

The day the precept is issued is known as the "teste" and the day the grand jury is to convene is the "return." In 1797, the time between the teste and the return in treason trials was fixed, by legal precedent, at fifteen days (exclusive of the days of the teste and return). Riddell, "Canadian state Trials," 330 nlo.

A grand jury is a group of individuals whose duty is to receive complaints and accusations in criminal cases, consider the evidence presented by the 


\section{7 (continued)}

prosecution, and then determine whether a crime has probably been committed and whether the accused probably committed the crime. If the grand jury is satisfied that such "probable cause" exists, then it will issue a "true bill" (also known as an indictment), but if the grand jury determines that "probable cause" does not exist, then it will return a "no bill." The grand jury is typically larger then the ordinary trial jury. In addition, it is only an accusatory body and it does not determine guilt or innocence. Black's Law Dictionary, Fifth Edition, 768. 
CHAPTER IX

THE GRAND JURY

The prosecution could not have hoped for a more favorable grand jury. First, amongst its members were two who were eager to prove their loyalty to the crown:

George AlIsopp (c.1733-1805), long-time businessman and the most militant opponent of the colonial administration until his retirement from politics in 1791; his son, Carleton, was a firm believer in French republicanism and Allsopp was embarrassed when Carleton emigrated to France in 1793, /198/

and

Peter stuart (d. 1806), one of the principal merchants involved in the Gulf of St. Lawrence fisheries, justice of the peace, and foreman of the grand jury that indicted the Road Act rioters the previous March, once had a domestic servant, Jean-Baptiste Levesque, who helped provoke a riot in Quebec City during a military parade in 1794 by throwing up his hat and shouting "Vivent Les Francois!" /199/

In addition, the grand jury included several current and former colonial and British military administrators.

198 David Roberts, "George Allsopp," DCB, Vol. 5, 19-23; Greenwood, Legacies of Fear, 148-149.

199 Greenwood, Legacies of Fear, 148-149; Quebec Gazette, 6 April 1797, 19 July 1804; Wade, "Quebec and the French Revolution," 366; David Roberts, "James Tod," DCB, Vol. 5, 816; Moogk, "John Young," DCB, Vol 5, 881; Andre Morel, "David Lynd," DCB, Vol. 5, 509. 
For instance, the foreman of the grand jury, Francis Le Maistre (c. 1743-1805), was the lieutenant governor of Gaspe and the inspector of trade and fisheries for the Labrador coast. /200/ The other administrators on the grand jury were:

John Coffin (1729-1808), attorney, justice of the peace, commissioner of police for both the town and district of Quebec, and surveyor general of woods for all of Lower Canada, /201/

John Craigie (c.1757-1813), commissary general for the British army in Canada, member of the Lower Canadian House of Assembly, and son-in-law of John Coffin, /202/

Georges-Hippolyte Le Comte Dupre (17381797), military commissioner for corvees and for the transport of military provisions and stores in Quebec, deputy road commissioner for Montreal, recent member of the Lower Canadian House of Assembly, and inspector of police in Montreal, /203/

James Frost (c.1745-1803), captain of the port of Quebec, /204/

200 David Lee, "Francis Le Maistre," DCB, Vol. 5, 485-486; Greenwood, Legacies of Fear, 149 .

201 Marie-Paule LaBreque, "John Coffin," DCB, Vol. 5, 190-191; Greenwood, Legacies of Fear, 149; Morel, "David Lynd," DCB, Vol. 5, 509.

202 Christian Rioux, "John Craigie," DCB, Vol. 5, 214-215; Greenwood, Legacies of Fear, 149.

203 A.J.H. Richardson, "Georges-Hippolyte Le comte Dupre," in Dictionary of Canadian Biography, Vol. 4, (Toronto: University of Toronto Press, 1979), 441-442; Greenwood, Legacies of Fear, 149; Quebec Gazette, 7 December 1797.

204 Roch Lauzier, "James Frost," DCB, Vol. 5, 334-335. 
Kenelm Chandler (c.1737-1803), former head of the civil branch of the Board of ordnance in the former colony of Quebec and the former head of a colonial commission to report on the legal status of the Jesuit estates in Quebec, /205/

and

Augustin-Jerome Raby (1745-1822), superintendent of the St. Lawrence shipping pilots and member of the Lower Canadian House of Assembly, /206/

other members of the grand jury included:

Louis Turgeon (1762-1827), justice of the peace and seigneur, /207/

Louis Duniere (1723-1806), merchant, militia officer, recent member of the Lower Canadian House of Assembly, and brother-in-law of fellow grand juror Kenelm Chandler, /208/

Jacques-Nicolas Perrault (1750-1812), merchant, seigneur, militia officer, and justice of the peace, /209/

205 Glenn A. Steppler, "Kenelm Chandler," DCB, Vol. 5, 181-183.

206 Roch Lauzier, "Augustin-Jerome Raby," DCB, Vol. 6, 626-627.

207 Celine Cyr, "Louis Turgeon," DCB, Vol. 6, 787-788.

208 Stanley Brehaut Ryerson, "Louis Duniere," DCB, Vol. 5, 283-284.

209 Pierre Matteau, "Jacques-Nicolas Perrault," DCB, Vol. 5, 667-668. 
Nathaniel Taylor (d. 1806), the justice of the peace who took the pre-trial deposition of one of the prosecution's witnesses, Charles Frichet, /210/

Louis Germain (d. 1799), merchant, /211/

Rene-Hippolyte Laforce (1728-1802), ship's captain, lieutenant-colonel of the militia at Quebec city and vicinity, former officer in the French and, after the cession of Quebec to Britain, English navies, and member of the Road Act grand jury in March, 1797, /212/

John Purss (1732-1803), merchant and justice of the peace, /213/

Joseph Drapeau (1752-1810), merchant, owner of seven seigneuries, militia officer, and member of the Road Act grand jury, /214/

Alexandre Dumas (c.1726-1802), businessman, militia officer, lawyer, and member of the Lower Canadian House of Assembly, /215/

210 Quebec Gazette, 17 May 1785, 10 April 1806; Deposition of Charles Frichet, May 12, 1797, Canadian Archives, Series Q, Vol. 79-1, 13, in Brymner, "French Republican Designs on Canada," Note D, 69-70.

211 Johanne Noel and Renald Lessard, "Rene Kimber," in Dictionary of Canadian Biography, Vol. 7, (Toronto: University of Toronto Press, 1988), 468 ; Quebec Gazette, 21 March 1799, 9 May 1799, 10 April 1800.

Yvon Desloges, "Rene-Hippolyte Laforce," DCB, Vol. 5, 470; Quebec Gazette, 6 April 1797.

Andre Berube, "John Purss," DCB, Vol. 5, 699-700; Morel, "David Lynd," DCB, Vol. 5, 509. DCB, Vol. 5, 269-271; Quebec Gazette, 6 April 1797. 
Francis Filion, member of the Road Act grand jury, /216/

Jacob Danford, co-owner of the Grosse-Isle, an island in the lower St. Lawrence, /217/

Pierre Langlois (1750-1830), businessman, defeated in a bid for election to the Lower Canadian House of Assembly in 1796, /218/

and

Charles Pinguet (c. 1739-1821), member of the Road Act grand jury. /219/

In addition, several of these men were probably suspicious of, or felt ill-will against, the Americans and, therefore, might have been inclined to grant an indictment against a United States citizen, especially one accused of plotting to overthrow the colonial government. At least nine of them (Chandler, Coffin, Drapeau, Dumas, Duniere, Frost, Laforce, Le Comte Dupre, and Le Maistre) defended Quebec City against the Continental Army during the Revolutionary War. Furthermore, coffin was born in Boston and had to flee to Quebec in 1775 because of his loyalist beliefs; Le Comet Dupre was a prisoner of the Americans during the war and, after his release, was assigned to root

216 Quebec Gazette, 6 April 1797.

217 Roberts, "James Tod," DCB, Vol. 5, 817.

218 Deschenes, Dictionnaire des parlementaires du Quebec, 429 . 
out spies and collaborators; and Chandler helped American loyalist settlers who came to Quebec after the conflict. Also, Le Maistre was a thirty year veteran of the British army and he, along with coffin and Purss, were officers in the local militia while they served on the grand jury. Finally, at least two (Coffin and Germain) were members of the Association, the body established by James Monk in 1794 to support British rule, and at least six others (Drapeau, Langlois, Pinquet, Purss, Taylor, and Turgeon) had signed the loyalty oath that the Association drafted that year. /220/

After the grand jury was sworn in, Chief Justice osgoode read a long charge to the jurors, beginning with the statement that recent indictments in Montreal (i.e., Bizette and the Provencals) and arrests in Quebec (David McLane) provided "abundant proof" for the value of

220 Lee, "Francis Le Maistre," DCB, Vol. 5, 485-486; LaBreque, "John Coffin," DCB, Vol. 5, 190-191; Richardson, "Georges-Hippolyte Le Comte Dupre," DCB, Vol. 4, 44I-442; Steppler, "Kenelm Chandler," DCB, Vol. 5, 181-183; Cyr, "Louis Turgeon," DCB, Vo. 6, 787-788; Ryerson, "Louis Duniere," DCB, Vol. 5, 283-284; Desloges, "Rene-Hippolyte Laforce," DCB, Vol. 5, 470; Berube, "John Purss," DCB, Vol. 5, 699-700; Cyr and Dufour, "Joseph Drapeau," DCB, Vol. 5, 269-271; Roberts, "Alexandre Dumas," DCB, Vol. 5, 276-278; Lauzier, "James Frost," DCB, Vo1. 5, 334-335; Quebec Gazette, 17 May 1785, 3 July 1794, $10 \mathrm{July} 1794,6$ April 1797, 10 April 1806. 
Sewell's Better Preservation Act, but that Governor

Prescott had issued his special commission:

in tenderness to the parties [McLane] committed [in custody] - to relieve them from a long confinement should they be innocent, or for the benefit of a prompt example should they be guilty. (emphasis added) /221/

Therefore, it was now the grand jury's duty:

to inquire into such charges as shall be laid before you, respecting the crimes of

high treason, or misprision of treason, within this district, and either to find or to ignore the same; and also to present any persons whom you may know to have committed the like crimes, should any such have come within your

knowledge. /222/

osgoode then reminded the jurors that, until recently,

the Canadians had "cheerfully" submitted themselves to the

laws of the colony, but that:

emissaries have been sent forth [from France], as well native as proselytes, under the

pretence of diffusing liberty, to disturb the quiet of all settled governments. Every symptom of disobedience, and the few instances of marked disaffection, that have appeared in this colony, may be traced to this cause of delusion. It is therefore some consolation to reflect that the evil is not of native growth, but has been introduced by the insidious arts of mischievous foreigners, practising on the minds of the ignorant and credulous natives. /223/ Grand Jury, June 12, 1797, in 26 State Trials 721, 722 . 
Therefore, since arrests had been made for crimes that had never been perpetrated before in the colony, Osgoode felt that it was the court's duty to explain the law surrounding treason. After giving a general background as to the history of the crime, the judge specified the seven acts which, at that time, were treasonable. /224/ In describing the treason of "adhering to the king's enemies, giving them aid and assistance within the realm, or elsewhere," Osgoode gave the broadest definition possible, stating that "it is not necessary [that] the aid and assistance intended should actually be carried to effect" and concluded that:

should any person being a confederate with, or employed by the king's enemies, declare an intention of coming into the province [Lower Canada], at a given or any time, with a design of promoting an insurrection, either to

Under British law in 1797, there were seven catagories of treason. To quote osgoode, these were:

The first is the compassing of the death of the king, queen, or prince, and declaring the same by an overt act.

The second is, the violation of the king's consort, the king's eldest daughter unmarried, or the prince's wife. 
surprise a king's fortress or to deliver any part of the province into the hands of the enemy, and he do actually come in with such intention, the same is unquestionably an overt act of adherence and is high treason. /225/

The Chief Justice also discussed the treason of plotting to depose and kill the king, pointing out that the monarch's death is always comprehended by his enemies and, since the pertinent statute has no limitation of place, then it was to be taken in a general sense and whether an

224 (continued)

The third, the levying of war against the king in his realm.

The fourth is, the adhering to the king's enemies, giving them aid and assistance within the realm, or elsewhere.

The fifth, the counterfeiting [of] the great or privy seal.

The sixth, the counterfeiting [of] the king's coin, or bringing counterfeit coin into the realm.

The seventh, the killing of the chancellor, treasurer, justice of the one bench or other, justices in Eyre, justices of assize, justices of Oyer and Terminer in their places doing their offices. Chief Justice William Osgoode's Charge to the Grand Jury, June 12, 1797, in 26 state Trials 721,725 .

225 Chief Justice William Osgoode's Charge to the Grand Jury, June 12, 1797, in 26 state Trials 721,728 . 
indictment of compassing the king's death is pursued was strictly within the prosecution's discretion. /226/

Osgoode further pointed out that treason is based on the concept of allegiance and that:

Every person, being within the king's dominions, owes him allegiance. If a subject, his allegiance is natural, if an alien it is temporary . . .

Whilst an alien friend continues peaceably in the king's dominions he is entitled, in common with the king's subjects, to the protection of the law, from which he may obtain redress for any injury to his person or property; in return for this protection he owes the duty of allegiance. /227/

Therefore, if a friendly alien came into Lower Canada with the intent of adhering (as defined by osgoode) to the king's enemies, then that person is breaching the duty of allegiance that he owes to the British monarch and is guilty of treason. /228/

Finally, osgoode instructed the grand jury that:

the duties of your office do at this period, involve the most serious and important considerations. Should you have reason to credit the evidence that will probably be produced, you will find that a design has been

26 State Trials 721, 729; Greenwood, "The Treason Trial," 9 . Grand Jury, June 12, 1797, in 26 state Trials $721,729$. 
some time since on foot, which, if carried into successful execution, would subvert the government under which we live, and endanger the life, liberty, and property of all his majesty's faithful subjects in this province. These are serious consequences. But as it would ill become a court of justice to excite your feelings by a representation of projected evils, so, I trust, it is unnecessary to recommend to you to enter upon the inquiry with calmness and deliberation. Gentlemen of your education and experience, will, of course, pay little regard to idle reports, or vain surmises, should the charge be thus weakly supported; but should probable evidence be laid before you by two witnesses tending to fix the perpetration of any one of the overt acts, charged in the indictment (for due proof of any one of the overt acts will support a conviction), you will think it incumbent on you to prefer an accusation against the party that his innocence or guilt may appear by a verdict of the country. /229/

The transcript of the proceedings does not indicate when the prosecution appeared before the grand jury nor what evidence it presented of Mclane's crimes. However, the court was eventually adjourned to June 14 th at which time the grand jury unanimously issued a true bill of indictment against David McLane for treason. /230/

229 Chief Justice William Osgoode's Charge to the Grand Jury, June 12, 1797, in 26 state Trials 721, 730-73I.

As an accustory body, the grand jury considers only the evidence presented by the prosecution in its determination whether a crime has probably been committed. Black, Black's Law Dictionary, Fifth Edition, 786.

See, also, footnote 197 . 


\section{CHAPTER $\mathrm{X}$}

\section{THE LAWYERS AND THE INDICTMENT}

Immediately after the grand jury presented its indictment, the sheriff was ordered by the court to provide Attorney General Sewell, who was one of the prosecuting attorneys in the case, with a list of the potential jurors (along with their professions and places of residence) so that sewell could deliver that information to Mclane. Next, McLane was "brought to the bar" and informed that an indictment for high treason had been issued against him and that it was sewell's duty to provide him with a copy of the indictment as well as copies of the list of potential jurors and of the witnesses who would testify against him. Then, as required by law, Chief Justice osgoode advised Mclane that he was entitled to appointed counsel. McLane indicated that he wanted the help and the court immediately assigned George Pyke and George Germaine Sackville Francklin as his attorneys. /231/

Both Pyke and Francklin were young lawyers who were inexperienced and unlikely to challenge the English elite 
of the colony. Pyke (1775-1851), only twenty-two years old, had studied law in Nova Scotia under Richard John Uniacke, the conservative pro-British solicitor general of the colony, and was admitted to the bar on December 6 , 1796, only seven months before his assignment as Mclane's lawyer. Furthermore, it is believed by historians that, at about the time he became an attorney, Pyke came under the guiding influence of Chief Justice Monk; whatever happened, it is clear that, shortly after McLane's trial, Pyke began a highly successful political and judicial career and that his initial positions were obtained through political patronage. $/ 232 /$ But if Pyke's appointment as McLane's lawyer was questionable, then that of his co-counsel, Francklin (d. 1799) was astounding. Admitted to the bar on January 23,1797 , less than six months before the trial, Francklin articled /233/ for five years (1792-1797) in the

232 Greenwood, Legacies of Fear, 155; Jacques Boucher, "George Pyke," in Dictionary of Canadian Biography, Vol. 8. (Toronto: University of Toronto Press, 1983), 726.

233 Under English law, anyone who wishes to become an attorney must first serve, or "article," as a clerk in the office of an established lawyer for a period of time set by statute during which the future attorney is instructed in the ways of the legal profession. Black, Black's Law Dictionary, Fifth Edition, 102. 
law office of Attorney General sewell, who was now the senior prosecuting attorney in the McLane case, and was living with sewell and his family at the entire time of the McLane proceeding. Furthermore, up to a month before the trial, Francklin was the attorney for prosecution witness william cushing and was actively trying to procure for Cushing the immediate possession of the township that he had been promised in exchange for his testimony at the trial. /234/

Opposing Pyke and Francklin were the prosecutors: Alexis Caron and Jonathan Sewell. /235/ Caron (17641827), a Canadian attorney who'was admitted to the bar in 1791, was the junior member of the team and would play only the minor role of outlining to the jury the fourteen counts of treason that McLane was charged with. /236/ The senior prosecutor, sewell (1766-1839), was the son of the last

234 Quebec Gazette, 26 January 1797, 14 November 1799; Greenwood, "Garrison Mentality," 144-145, 145n130; Greenwood, "The Treason Trial," 7-8; F. Murray Greenwood and James H. Lambert, "Jonathan Sewell (Sewall)," DCB, Vol. 7, 785 . 26 state Trials 721,747 .

236 Quebec Gazette, I December 1791; Deschenes, Dictionnaire des parlementaires du Quebec, 129-130; Riddell, "Canadian State Trials," 331n14; 26 State Trials 721, 748-750. 
loyalist Attorney General of Massachusetts and, at eight years of age, witnessed the sacking of his home by American revolutionaries. In 1775, sewell fled to England with his family, but came to New Brunswick in 1785 to study law. In 1789, he moved to Quebec and was admitted to the bar. Accepted by Quebec's British elite, Sewell, with the help of Governor Lord Dorchester and Chief Justice William Smith, secured the position of Solicitor General in 1793. In that role, he worked with then-Attorney General Monk to suppress the Militia Act riots in 1794 (which both he and Monk believed were caused by French and American provocators) and, after Monk became a judge, sewell prosecuted the uncompleted cases. In 1795, with the support of Dorchester and Chief Justice osgoode, he became Attorney General. When the Road Act riots broke out the next year, sewell believed that the rioters were directed by the French and, on his recommendation, arrests were made in Quebec City and troops were sent to Montreal. After the riots, he continued to believe, like most of the English in Lower Canada, that the colony's established order was threatened from both inside and out and he drafted the Better Preservation Act of 1797 which suspended habeas corpus in the province. And, in November, 1796, he helped negotiate the transfer of two townships in exchange 
for Elmer Cushing's and William Barnard's testimony at the McLane trial. /237/

After the appointment of McLane's lawyers, the court then ordered that the proceedings be adjourned until June 30 th when McLane would be formally arraigned. Three days later, on Saturday, June 17th, a copy of the indictment, along with a list of the individuals impanelled as potential jurors by the sheriff and a list of the witnesses to be called by the prosecution. /238/

on June 30th, McLane was arraigned before Chief Justice osgoode, Chief Justice Monk, Judge Dunn, and others not named in the transcript of the proceedings. The indictment against McLane was read; enormously long and printed on eighteen pages of octavo size paper, /239/ the document accused McLane of two counts of treason; first, that he:

maliciously and traitorously with force and arms did compass [,] imagine and intend to despose our said sovereign lord the king from the royal state title [,] power and government of this province of Lower Canada . . . and to bring and put our sovereign lord the king to death. /240/

Greenwood and Lambert, "Jonathan Sewell (Sewall)," DCB, Vol. 7, 782-784; Greenwood, "The Treason Trial," 5-6. 26 State Trials 721, 731-732. Riddell, "Canadian state Trials," 325. 
Second, that McLane:

maliciously and traitorously was adhering to [,] aiding and comforting the ... persons exercising the powers of government in France then being enemies of our said sovereign lord the king. /241/

Each count alleged the identical fourteen overt acts; specifically, McLane was accused of:

1) Conspiring with persons unknown to solicit and incite the French government into invading Lower Canada;

2) Actually soliciting and inciting the French government to invade the colony;

3) Conspiring with the French government to incite a rebeliion in Lower Canada and to plan an invasion of the colony;

4) Conspiring with persons unknown to incite an insurrection in Lower Canada and of assisting and persuading local inhabitants in the colony to aid the French government in an invasion;

5) Attempting to persuade, and actually persuading, inhabitants of Lower Canada to rebel and to aid the French in an invasion;

6) Soliciting and persuading foreigners to incite an insurrection in Lower Canada, to make war against the British authorities, and to assist a French invasion;

7) Raising and making ready several men to take up arms and levy war against the colonial authorities and to aid a French invasion;

8) Conspiring with persons unknown to secret arms and ammunition into Lower Canada with the intent to use the materials in a local rebellion and in assisting a French invasion; 
9) Collecting intelligence as to who in the colony were and were not likely to support and assist a French invasion with the intent of communicating this information to the French government;

10) Acquiring knowledge of the British military strength in Montreal and determining how the city could be attacked for the purpose of assisting the French in their war against Britain;

11) Intending to reveal all the information that he had obtained to the French government;

12) Secretly entering Quebec city under the false name of "Jacob Felt;"

13) Conspiring with persons unknown to seize Quebec City, to slaughter its soldiers and populace, and to deliver the city to the French;

and

14) Entering Quebec city with the intent to seize it, slaughter its inhabitants, and

deliver it to the French. /242/

The indictment, however, did not make any distinction between events that occurred in Lower Canada and the United states nor did it allege that the French had received the information collected by McLane or benefit in any way from his activities. /243/

After the indictment was read, McLane pled "Not Guilty" and his trial was scheduled for July 7th. In addition, the sheriff was ordered to summon the 
potential jurors and to gather them together at seven o'clock on the morning of the 7 th. The court then adjourned for one week. /244/ 
CHAPTER XI

THE JURY

The court convened precisely at seven $0^{\prime}$ clock in the morning on July 7 th at the Quebec courthouse. On the bench were Chief Justice Osgoode, Chief Justice Monk, Judge Dunn, Finlay, Baby, Juchereau Duchesnay, and Young; before them were all four prosecuting and defense lawyers. Also present was the largest crowd even to attend a trial in Quebec up to that date and, although the temperature would reach over 100 degrees, spectators filled the galleries all day. Immediately after McLane was brought into the courtroom, the potential jurors were questioned. /245/

The jury panel included eighty-six names of which only thirty-three to thirty-five were French. /246/ Thus, even

24526 state Trials 721, 747; Greenwood, Legacies of Fear, 156 .

246 A jury panel is a group of individuals from which a grand jury or a petit jury may be chosen. Black, Black's Law Dictionary, Fifth Edition, 769.

Canadians had been allowed to serve on juries since 1766. "An ORDINANCE, To alter and amend an ordinance of $\mathrm{His}$ Excellency the Governor and His Majesty's Council of this Province, passed the Seventeenth Day of September 1764," July 1, 1766, in Shortt and Doughty, Canadian Archives: Documents Relating to the Constitutional History of Canada, 1759-1791, Part 1, 249-250. 
if the defense exercised all of their thirty-five peremptory challenges, the prosecution would still be able to keep any Canadians from serving on the jury and that was important because a conviction required an unanimous verdict and because it was widely believed by the British that most Canadians were disloyal. /247/ Furthermore, in a significant divergence from the practice of alternating the order (i.e., English, French, English, French, and so on) in which potential jurors were examined about their competency and prejudices, the first fourteen all had English names as did also fourteen of the next eighteen, thus making it easy for the prosecution to insure the selection of an all-English jury. /248/ Finally, the jury panel itself was peculiar because it included several members of the British mercantile elite in Quebec City;

Greenwood, "The Treason Trial," 7.

A party may call into question, or "challenge," the capability of a person to serve on a jury. A peremptory challenge is a challenge for which no reason has to be given to the court to keep a person from serving on the jury. A challenge for cause requires the party to provide the court with a satisfactory reason (such as bias) as to why the prospective juror should not be seated and, before it acts, the court must be convinced that the reason is compelling. Black, Black's Law Dictionary, Fifth Edition, 209, 769.

Mclane was entitled to 35 peremptory challenges; there is no indication that his challenges for cause were restricted to any amount. See footnote 176. 
typically, such individuals were not called for jury duty except to serve on the grand jury while the petit for trial) juries tended to be dominated by clerks, artisans, and shopkeepers. /249/ McLane's lawyers, inexperienced and unlikely to challenge the city's elite, made no challenge to the panel as a whole for its composition or for the order by which the names were called nor did they challenge, either peremptorily or for cause, the first eight jurors, seven of whom were leading merchants. In all, the defense issued only twenty-four challenges and the prosecution eleven with eight jurors selected from the first fourteen names and three from the next eighteen; the last juror selected was prospective juror number forty-six. $1250 /$

In the end, the jury consisted of eight prominent import-export merchants and four others who were dependent upon the economic elite of Quebec city (even though three of them were well established in their own fields). /251/ 
The twelve jurors were:

John Blackwood (d. 1819), import-export merchant, /252/

John Crawford (d. 1803), import-export merchant, /253/

John Mure (d. 1823), import-export merchant, /254/

John Jones (c.1752-1818), auctioneerbroker, /255/

James Mason Goddard (c.1778-1817), operator of the large brewery at St. Roch, /256/

252 Jean-Pierre Wallot, "John Blackwood," DCB, Vol. 5, 85; Greenwood, "The Treason Trial," 8.

253 Greenwood, Legacies of Fear, 157-158; Quebec Gazette, 17 November 1803.

254 David Roberts, "John Mure," 드, Vol. 6, 531.

255 Marianna O'Gallagher, "John Jones," in DCB, Vol. 5, 459-460; Greenwood, Legacies of Fear, 157-158.

Greenwood identifies the John Jones who was the auctioneer-broker as the Jones who served on the McLane jury. However, O'Gallagher, who wrote the biography of Jones in the Dictionary of Canadian Biography, says that a namesake, of whom little is known, sat on the jury. For purposes of analyzing the composition and biases of the McLane jury, it is assumed that Greenwood's research is correct. Greenwood, Legacies of Fear, 158; O'Gallagher, "John Jones," DCB, Vol. 5, 462n.

256 Greenwood, Legacies of Fear, 158; Quebec Gazette, 4 December 1817; Peter N. Moogk, "John Young," DCB, Vol. 5, 879. 
Henry Cull (1753-1833), import-export merchant, /257/

John Painter (c.1745-1815), import-export merchant, /258/

David Monro (Munro) (c.1765-1834), importexport merchant, /259/

James Irvine (1766-1829), ship's chandler and storekeeper, /260/

James Orkney (1760-1832), clock and watchmaker, /261/

Robert Morrogh (d. after 1820), importexport merchant, /262/

and

George Symes (d. after 1822), importexport merchant. /263/

The defense used only twenty-four of their thirty-five peremptory challenges and, yet, one juror who clearly

\footnotetext{
257 Andree Desilets, "Henry Cull," DCB, Vol. 6, 174; Greenwood, Legacies of Fear, 157.

258 Roch Lauzier, "John Painter," DCB, Vol. 5, 647; Greenwood, Legacies of Fear, 157.

259 Marie-France Fortier, "David Monro (Munro)," DCB, Vol. 6, 515; Greenwood, Legacies of Fear, 157.

260 Ginette Bernatchez, "James Irvine," DCB, Vol. 6, 346; Greenwood, Legacies of Fear, 158 .

261 Rene Villeneuve, "James orkney," in DCB, Vol. 6, 556; Greenwood, Legacies of Fear, 158.

262 Greenwood, Legacies of Fear, 157; Quebec Gazette, 13 August 1821. 
should have been challeged was John Blackwood. A justice of the peace, he actually helped gather some of the evidence that was used against McLane. But even if McLane's lawyers were not aware of Blackwood's role, there were other facts in Blackwood's past that should have caused them to suspect a bias in favor of maintaining the established order if not an outright prejudice against Americans; Blackwood helped defend Quebec City against the American invasion that occurred only twenty-two years before, he was currently an officer in the local militia and a member of the governing council of the Quebec Assembly which brought together people who had defended the colony against the 1775-1776 American invasion, he had taken a militant role within the patriotic societies of Lower Canada, and he was a member of Monk's Association. /264/

But it is also important to note that most of the other jurors also had something in their backgrounds which would have called into question their objectivity and their ability not to be unduly swayed. First, six of them (Blackwood, Crawford, Cull, Monro, Painter, and Symes) sat on the accusing grand jury that indicted the Road Act rioters the previous March and, thus, had a detailed

264 Greenwood, "The Treason Trial," 8; Wallot, "John Blackwood," DCB, Vol. 5, 85-88. 
understanding of Attorney General Sewell's French plot interpretation of the disturbances; in fact, Painter, as justice of the peace, had helped prepare the prosecution's case against the Road Act rioters. Second, at least five of the jurors (Crawford, Cull, Jones, Morrogh, and Painter) were officers of the Quebec Battalion of the British Militia (officer rank in the unit was a sign of social status) and two others (Monro and Mure) might have been ordinary militiamen in the unit. Third, at least five of the jurors had personal or economic ties with some of the judges and court personnel; Goddard was the operator at a brewery of which John Young was the principal owner, Mure had previous dealings with Antoine Juchereau Duchesnay and was close enough of a friend of James McGill to have him serve as a witness at his wedding, cull was a good friend of William Vondenvelden (the court reporter), Jones once ran a newspaper with Vondenvelden, and Monro had been authorized to give discharges to John Lees' debtors in 1791. Fourth, a few of the jurors might have had political or social ambitions that a "guilty" verdict might advance; Irvine started to circulate, shortly after the trial, among those few who benefited from government patronage, Monro and Mure became officers in the Quebec Battalion in 1800, and Mure started a political career that same year. And there was the influence that arises from serving on a body with people that you know; Blackwood was another witness at 
Mure's wedding and all twelve jurors (as well as Chief Justice Osgoode, Chief Justice Monk, Judges De Bonne, Dunn, and Williams, and Attorney General Sewell) were members (and many were officers) of the Quebec Fire society, an association that offered its members a type of fire insurance, worked to prevent fires, and fought conflagrations when they broke out. /265/

Finally, it is interesting to note that the prosecution did not challenge Irvine's place on the jury for he was the brother-in-law of one of the defense attorneys, George Pyke. /266/ Perhaps the prosecution believed Irvine would have a greater affect upon Pyke's performance in the courtroom than Pyke would have upon Irvine's as a juror.

265 Greenwood, Iegacies of Fear, 157-158; Quebec Gazette, 17 May 1787, 28 January 1790, 31 March 1791, 23 October 1794, 25 June 1795, 30 March 1797, 6 April 1797, 29 June 1797 (Supp.)., 17 November 1803; 4 December 1817, 13 August 1821, 25 August 1823; Roberts, "John Mure," DCB, Vol. 6, 531-534; O'Gallagher, "John Jones," DCB, Vol. 5, 549-562: Desilets, "Henry Cull," DCB, Vol. 6, 174-175; Lauzier, "John Painter," $\underline{\underline{C C B}}$, Vol. 5, 647-648; Fortier, "David Monro (Munro)," DCB, Vol. 6, 515-516; Bernatchez, "James Irvine," DCB, Vol. 6, 346-347; Villeneuve, "James Orkney," DCB, Vol. 6, 556-557; Moogk, "John Young," DCB, Vol. 5, 879. Jacques Boucher, "George Pyke," DCB, Vol. 8, 726. 
CHAPTER XII

\section{TESTIMONY, LEGAL ARGUMENTS, AND SENTENCING}

Once the jury was selected and sworn in, the court clerk had McLane hold up his hand in order to identify himself to the jurors. The clerk then read the entire indictment to the jury and instructed its members that it was their duty to determine whether Mclane was guilty and, if he was, to inquire as to what property he had at the time he committed the treason and what he acquired afterward. /267/

The Crown's junior counsel, Alexis Caron, opened by summarizing the indictment and advising the jury that if

26 state Trials $721,747-748$.

Under British law in 1797, a conviction of treason not only brought the death penalty, but it also meant the forfeiture to the crown of all of the lands that the defendant acquired since the commission of the treason as well as all of the defendant's rights of entry upon any lands, all of his profits or rents from land, and his personal property. Often, as in Mclane's case, no evidence would be offered regarding these matters and the jury would find "None to our knowledge" when pronouncing their verdict. Furthermore, a convicted traitor could not inherit nor could anyone inherit through him (e.g., his son could not inherit the estate of the defendant's parents). Riddell, "Canadian State Trials," 331 1n15; Greenwood, Legacies of Fear, 305n42. 
the prosecution's witnesses "prove the charge" against Mclane, then it was the jury's duty to convict him; this was Caron's only role in the trial. /268/ Attorney General sewell then gave a lengthy address in which he first laid out the prosecution's interpretation of the statutes that McLane was accused of violating. As to plotting the king's death, sewell argued that the law was not limited to compassing the monarch's physical demise, but that:

The king is partly a natural, partly a political character; in the former he enjoys a natural life, in the latter a political existence; and to aim at the destruction of the one, or of the other, constitutes the crime of high treason; for, the political or civil death, as well as the natural death of the sovereign is clearly within the purview of the statute.

An attempt to destroy the political existence of the sovereign, tends in fact to destroy the king in person; for, experience, and recent experience has shown, that the interval between the dethronement of princes, and their deaths is but short. But that is not the only consequence; it tends also to annihilate the constitution of government of which the sovereign is the head. /269/ July 7, 1797, in 26 state Trials 721, 750-751. 
And regarding the charge that McLane adhered to the king's enemies, sewell stated that:

this species of treason has been uniformly held to include all, who being bound by any description of allegiance to our sovereign, have given aid or assistance to his enemies in any place whatever; and by the same authority it has been repeatedly decided, that it is not necessary that such aid or assistance should actually be given, but that an intention to aid or assist the king's enemies, where the party has done what lay in his power to effect that intention, was clearly treason. /270/

sewell went on to state that, unlike other crimes, the mere intent to commit the particular categories of treason that McLane was charged with was a crime in and of itself and was sufficient to support a conviction. However, because one's intentions can only be proven by their acts, Sewell indicated that the indictment against McLane charged specific overt acts from which the jury can infer McLane's intent; he then presented, like caron before, a summary of the indictment, /271/ concluding that if the overt acts mentioned in the document were "substantiated by evidence clear and satisfactory to your minds," then the jury must convict McLane. /272/

270 Ibid., 751.

27126 State Trials 721, 751-754.

272 Opening Remarks of Attorney General Sewell, July 7, 1797, in 26 state Trials $721,754$. 
Sewell then went on to describe the terror that would

have followed had Mclane carried on with his plot:

If a rebellion had been raised or an invasion attempted without success, the horrors of war, a suspension of all civil rights, a daily and miserable apprehension of something yet worse to come, were nevertheless unavoidable consequences. But if the attempt had succeeded, what a scene of misery must have been opened - our properties, our lives, and, what is still more valuable than either, the happy constitution of our country, all that man can value in civil society, all that attaches us to existence, ourselves, our nearest and best connections, our government, our religion, our rational liberty, which we boast as British subjects, all must have been laid at the mercy of the French republic. What that mercy is, the black annals of the republic can best tell - . the horror and execration of posterity, in the blood of their lawful sovereign, in the blood of their nobility, in the blood of their clergy, in the blood of thousands of the best and most innocent of their citizens. /273/

The Attorney General explained to the jury that it was immaterial whether McLane was a British subject or an alien because, if the latter, he still owed a temporary allegiance to the king while in Lower Canada. From this point, sewell reviewed at great length the anticipated testimony of the prosecution's witnesses and, after a brief discussion about the role of overt acts in proving treason, concluded by stating that the charges against Mclane would be proved and that it was the jury's duty to find him 
guilty. /274/ There is no indication in the transcript that either defense lawyer gave any opening remarks but, instead, the testimony of the prosecution's first witness immediately followed sewell's comments.

There were seven witnesses against McLane; six were individuals who had been approached by the defendant during his travels of the previous year (Barnard, Cushing, Chandonet, Butterfield, Frichet, and Black) and the seventh was Herman Ryland, the man who arrested McLane. Each of the six testified in detail as to how and when they met McLane, how he tried to entice them into his plot, and of McLane's comments regarding his intentions and those of the French to seize Lower Canada; Ryland testified as to the events immediately surrounding McLane's arrest and his use of an alias. /275/

At the time of the trial, both Butterfield and Frichet were still in custody as admitted accomplices, but Butterfield was promised his freedom if he turned state's evidence; what promises, if any, were made to Frichet in exchange for his testimony are not known, but he was never

26 State Trials 721, 755-763. 
tried for treason. /276/ At the beginning of Butterfield's testimony, the defense objected to his examination on the grounds that he was an accomplice; relying on legal precedent, the Attorney General countered that the fact Butterfield was an accomplice went only to the credibility of his testimony and not to Butterfield's competency to testify. /277/ Chief Justice Osgoode ruled that "where previous testimony has been given, the evidence of an accomplice can certainly be received." /278/

The defense team also objected to testimony about conversations that occurred in Vermont on the grounds that they were spoken outside the county in which Quebec city is located. Again relying on precedent, sewell responded that the prosecution was entitled to present evidence (such as testimony of past conversations) of the overt acts underlying a charge of treason, wherever the acts were committed, so long as one of those acts occurred within the county of Quebec. /279/ Osgoode overruled the objection,

276 Greenwood, Legacies of Fear, 146, 154.

27726 State Trials $721,771$.

278 Ruling of Chief Justice William osgoode to an Objection on July 7, 1797, in 26 state Trials 721 , 771 . 
but warned sewell that "whatever overt acts you prove, committed out of the county of Quebec, cannot avail you, if you do not prove an overt act within that county." /280/ Both of the objections were made by Pyke. In addition, during his cross-examination of Barnard and Cushing, Pyke inquired about whether they had been promised anything (such as their townships) in return for their testimony, but both perjured themselves and denied that they were expecting any reward for their evidence. The defense team did not call any witnesses and, aside from the above, did little during the cross-examination of the prosecution's witnesses than emphasize that Mclane was an American citizen. /281/

There was one interesting bit of information that Mclane would later try to explain away. Cushing testified that McLane took out of his saddle bags a pair of shoes and pulled out, from a hole in one of them, a letter that was written in English and allegedly signed by Adet which

280 Ruling of Chief Justice William Osgoode to an Objection on July 7, 1797, in 26 State Trials 721, 763 . 
purported an interest on Adet's behalf in McLane's family affairs. Cushing also said that McLane claimed to have written the letter himself and to have had Adet sign it as proof, should the need arise, that he was employed by the French. Finally, according to McLane, the letter was written in such an obscure style so that, if he was arrested, the document could not be used against him. $1282 /$

After the close of the Crown's case, Mclane asked, and was given permission, to make a statement on his own behalf before his lawyers presented their arguments to the jury. /283/ His address did not specifically deny any of the evidence against him; indeed, he admitted virtually the Crown's entire case except for the compromising remarks that the prosecution's witnesses testified to. However, Mclane said that they:

may all be honest men, for aught I know; I have nothing in particular to object against them. But all are liable to mistake; and it is now

Ibid., 767.

At the time, it was the practice in British treason trials to invite the defendant to speak after his lawyers had made their statements. However, Chief Justice Osgoode agreed to "hear both him [Mclane] and you [his defense attorneys] in the order you may think proper to adopt." Wallis, "Treason and Treason Felony," 263; Ruling of Chief Justice William Osgoode on Defense Request on July 7, 1797 in 26 State Trials $721,779$. 
evident how much they have been mistaken. They have grossly mistaken my views, which were only views of trade, and not at all political. /284/

In his testimony, Mclane stated that he once ran a store with his brother-in-law, Jacob Felt, in Providence, Rhode Island, but that it was a highly unsuccessful affair. In the fall of 1795, Felt mentioned that a living might be made in Canada and, later, Mclane sent Felt there with some goods from their store to see what could be done while he stayed behind. Afterward, the store's finances got worse and McLane left for the Lake Champlain area to find Felt, eventually coming to st. Johns and later Montreal, meeting Butterfield and Barnard along the way and staying overnight at cushing's tavern. According to Mclane, he visited the mountain at Montreal merely as a matter of curiosity and, when questioned about the trip by cushing and told that he was "much suspected," showed Cushing the letter from Adet to show that he had proof of who he was. /285/ Mclane further stated that Adet's clerk had signed Adet's signature on the letter and that the document was the

Testimony of David McLane on July 7,1797 , in 26 State Trials $721,783$.

Mclane did not deny Cushing's testimony that the two had known each other for ten or eleven years. However, it is not clear from Mclane's testimony whether, when he was showing cushing the letter from Adet, if McLane was trying to prove to Cushing who he 
result of seeking, from the French Minister, a certificate allowing him to go to France to collect some property owned by his wife and her sister that had been left there by a now-deceased brother-in-law. In addition, McLane maintained that he had put the letter into his saddle bags and that it just happened to slip into the hole in his shoe. /286/

Mclane also testified that, after meeting with Cushing, he returned to the United states in the hope of catching a ship to France, but was unable to find one because:

I found the French, as the English had done before, took all our vessels they could

285 (continued)

was or if he was just showing Cushing that he had proof as to his identity should the need arise:

I thought it would be a good time to visit the mountain; I did so, and when I came back, I told Mr. Cushing where I had been; he said you should not mention that: I asked, why so; he said, because you are much suspected here; I asked why I was suspected, I would give good proof of who I was. (At which point, according to the testimony, McLane retrieved the letter from his saddle bags.) Testimony of David McLane on July 7, 1797, in 26 State Trials $721,781$.

See, also, footnote 111 . 
lay hold of, not only those bound to an enemy's port, but also those bound to their own ports. $/ 287 /$

Therefore, to avoid his creditors, McLane returned to Lake Champlain intending to buy timber on credit which he would, in Canada, exchange for horses that could be sold in the United States. McLane again met Butterfield and asked if he knew anyone who could take him into canada; Butterfield replied that he knew Frichet and agreed to fetch him. Not wanting to be found by his creditors, Mclane decided to use an alias and told Frichet that his name was "Jacob Felt." Frichet agreed to take Mclane to Quebec city to show him where to get the best horses; on the way, they even bought one. Once near the city, Mclane feared that his creditors may have gotten there ahead of them and, to avoid them, sent Frichet into town to find and return John Black. During McLane's conversation with $\mathrm{Black}$, the latter indicated that he was interested in purchasing some timber from McLane, but would not buy

Testimony of David Mclane on July 7, 1797, in 26 state Trials $721,782$.

The seizure of American merchantmen that were heading for the French West Indies was practiced by the British in 1794 as a tool in their war against France. In July, 1796, in response to the United States' ratification of Jay's Treaty with England, France began to seize cargo destined for British ports that were carried on American ships. Paterson, American Foreign Policy, 46, 52 . 
any until he had seen it. Also during their conversation, McLane presented two letters from Captain Hundsen of Vermont, one addressed to $\mathrm{Black}$ and the other to John Blackwood, stating that McLane had timber to sell. /288/ Black apparently knew Hundsen and, after seeing the correspondence, invited McLane to come to his home; however, Mclane still feared his creditors and communicated that to Black. When asked if any strangers from the United States had recently arrived in the area, Black said "no" and pressed Mclane to come to his home, but also recommended that McLane continue using the name "Jacob Felt." Also, because Hundsen's letters mentioned McLane by $h$ is real name, Black suggested that the letters be destroyed. Mclane eventually decided to come to Black's house, but since his creditors were unknown to Black and could be in the area without Black's knowledge, he consented to do so only after it was dark. McLane arrived at Black's residence about half past eight and was arrested two and a half hours later. Throughout all of this, Mclane did not account for the $\$ 140$ that he was carrying when he was arrested; he also did not explain why he had done so little business in Canada while looking for horses nor why 
he chose his business partner's name as an alias when his creditors, who would surely know his partner's identity, were so persistent as to follow him into another country. /289/

Pyke spoke to the jury immediately after McLane's address. After spending a large portion of his presentation praising the "pure and uncorrupt" nature of the English legal system "where justice is mingled with mercy, and where accusation and suspicion alone are not grounds for conviction," Pyke attacked the allegations against McLane. /290/ First, Pyke argued that the prosecution had failed to prove that McLane intended to cause the king's physical death and that there was, in fact, no evidence that his client had any such intention. 1291/ Furthermore, even if the Attorney General was correct and the law contemplated the compassing of the monarch's political demise, the idea that the dethronement of the sovereign could lead to the his physical death was inapplicable to Canada. Specifically:

it is absurd to suppose the act of any individual in this distant part of his majesty's dominions, could in the smallest

28926 State Trials 721, 780-783; Greenwood, Legacies of Fear, 161.

290 Closing Arguments of George Pyke on July 7, 1797, in 26 State Trials 721, 784.

29126 State Trials $721,785$. 
degree affect the sacred person of his majesty; nor indeed could it possibly have that tendency, should it even extend so far as to effect the separation of Canada from the dominion of the crown of Great Britain. /292/

As to the allegations of adhering and giving aid to the enemy, Pyke maintained that intent alone was not enough for a conviction and that it was necessary for the prosecution to prove that McLane had actually given "aid and information" to the French. Pyke concluded his remarks with a summary of McLane's testimony. /293/

Francklin then spoke. He, too, supported McLane's version of the facts and, like Pyke, argued that sewell's interpretation of the laws regarding the compassing of the king's death could not apply in Canada:

and it must strike you as monstrous to suppose, that the subversion of the government of this province would endanger his majesty's natural ife.

In England the case is different; it is there usual to charge persons, concerned in plots against the government, with compassing the king's death, and the reason... is, that experience has shown that between the dethronement and the grave of princes, the distance is very small. The same reasoning will not apply here. /294/

292 Closing Arguments of George Pyke on July 7, 1797, in 26 state Trials 721, 785.

29326 State Trials 721, 785-786.

294 Closing Arguments of George Francklin on July 7, 1797, in 26 state Trials 721, 787-788. 
Francklin hardly dealt with the charge of adhering to the king's enemies, simply trusting that the jury believed McLane's account of the events, but he did point out the inconsistency in Barnard's account of McLane continuing to convey secrets after being told by Barnard that he had spoken with the authorities. He also dismissed Butterfield and Frichet as "persons charged as accomplices, who . . being implicated themselves, endeavour to shift the burthen [sic] of guilt. . . in order to save themselves." In conclusion, Francklin spoke of "how scrupulouly juries in England have in modern times weighed the proof in trials of the present nature" and then left his client's fate to the jury "with confidence [because] gentlemen of your integrity and discernment will doubtless consider his case without bias or prejudice." /295/

Both Pyke and Francklin mentioned that McLane was an American citizen, but one defense that they did not raise was that he was not an alien friend who owed a temporary allegiance to the king, but an enemy alien who owed none and, therefore, could not be guilty of treason. At the time of the trial, there was little in British law on the George Francklin on July 7, 1797, in 26 state Trials $721,788-789$. 
subject of what allegiance an enemy alien owed to the Crown. However, what authority there was was explicit: an enemy alien who invaded the country, as well as one who was sent as a spy by a hostile power, owed no allegiance and, thus, could not be indicted for treason. And Mclane probably could have claimed to be such an enemy alien even though the United states was not at war with Britain. In a trial that was held one hundred years before, a British court ruled that a group of Hollanders who were among the crew of a French vessel (while France was at war with England) were enemy aliens so long as they were in the service of France. Indeed, in a civil case in Britain that was held just a few months after McLane's trial, a court reached the same conclusion regarding a German who was engaged in hostilites while serving in the military forces of the French Republic. Mclane was certainly a spy for the French government and he may have held a military commission; he told Cushing that he would personally lead the French attack on Montreal, he had a plan for the military seizure of Quebec City, and Black testified that Frichet not only identified Mclane as a French general, but that McLane himself had said as much. /296/ One can only surmise why McLane's lawyers did not follow this line of

296 Greenwood, Legacies of Fear, 168-169; Greenwood, "The Treason Trial," 10-11; 26 state Trials $721,768,775-778$. 
defense. As noted earlier, they were inexperienced and unlikely to do anything to challenge the elite of the colony. Similarly, they may have feared for their careers and professional advancement, especially in light of Francklin's long relationship with the Attorney General and Pyke's recently coming under the wing of Chief Justice Monk. It is also possible that they realized the enormous inconsistency of arguing that McLane was an enemy alien by virtue of being a spy or a military officer when their own client denied these very allegations and insisted that he was in Canada merely on business; indeed, they may have been obligated, professionally or otherwise, to support his version of the facts. Whatever happened, a strong defense that might have saved McLane was not made by his lawyers. After Francklin completed his arguments, the Attorney General gave his final presentation to the jury, pointing out the inconsistencies in McLane's testimony and his admissions. He also restated the prosecution's position that Mclane sought the political death of the monarch and that such an offense was included in the legal definition of "compassing the king's death" as well as the argument that the intention to give assistance to the king's enemies, without proof that one did actually aid or assist those enemies, is sufficient for a conviction. Sewell also spoke about McLane's accomplices, Butterfield and Frichet, and while advising the jury that it remained 
for them to determine how much weight to give to their testimony, observed that their stories were substantiated by the other witnesses. /297/ Finally, in a direct response to Francklin's comment of how recent juries in England had "weighed the proof" in treason trials, sewell quoted Edmund Burke in saying that those very trials were:

little better than schools for treason, of no use but to improve the dexterity of criminals in the mystery of evasion, or to show with what impunity men may conspire against the government and constitution of their country. /298/

Immediately after the Attorney General completed his remarks, Chief Justice Osgoode reviewed the case for the jury. Initially, he summarized the two charges and fourteen overt acts of treason that McLane was accused of committing and then proceeded with a detailed legal analysis of how intent alone, in treason cases, was sufficient for a conviction. /299/ While doing so, he made it clear that if the jury thought:

it unreasonable to impute to the prisoner the crime which constitutes the first charge brought against him, namely that of compassing the king's death . . . you may, if you think proper, direct your attention to the evidence July 7, 1797, in 26 state Trials 721, 792-793. 
given as tending to prove the second count in the indictment, which contains the charge of a declared treason and is therefore sufficient, if found, to support a conviction. /300/

osgoode then went over, in intricate detail, the testimony of each of the prosecution's witnesses, paraphrasing, and often quoting, everything that was said, but as he surveyed Mclane's testimony, all that he said was that "he [McLane] admits a number of the leading facts alleged against him by the witnesses; but attempts to put a different colour upon some, and to explain away others." /301/ The Chief Justice also explained in great depth why he felt eleven of the fourteen overt acts that McLane was charged with had been proven by the prosecution and stated that:

Should you believe the witnesses that have been produced, and no attempt has been made to impeach their credit (on the contrary, the prisoner, with a becoming spirit of candour, admits, for aught he knows, they may be all honest men), it is my duty to tell you, they have [been] proved sufficient, and more than sufficient to maintain the indictment. /302/

Summation of Chief Justice William Osgoode on July 7, 1797, in 26 state Trials 721, 794.

30126 State Trials 721, 798-808; summation of Chief Justice William Osgoode on July 7, 1797, in 26 State Trials 721,809 .

302 Summation of Chief Justice William Osgoode on July 7, 1797, in 26 state Trials 721, 810.

When outlining to the jury the overt acts that he thought had been proven, osgoode did not mention the allegations of 1 ) conspiring to solicit and incite the 
Osgoode concluded by informing the jury that:
Having thus endeavoured, gentlemen, to explain the law in this case, and having repeated the evidence, it remains for you to determine upon that evidence; for, the verdict must be yours. If you have any reasonable ground of doubt, I need not observe to you that it is the invariable direction of an English court of justice to lean to the side of mercy. If you disbelieve the evidence in all its parts you cannot convict the prisoner; on the other hand, if you believe the witnesses, and that the treasons charged against him, or either of them, have been clearly and satisfactorily proved, you will find him guilty: the whole is left to you to determine this issue according to your oath. /303/

\section{2 (continued)}

French government to invade Lower Canada, 2) actually soliciting and inciting the French to invade, and 3) conspiring to incite an insurrection in Lower canada and to persuade the colony's inhabitants to aid the French government in an invasion of the colony. While no evidence was introduced to support the first two allegations, osgoode's failure to mention the third was probably an oversight. See, 26 state Trials 721, 809-810.

While Osgoode's analysis of the evidence may have been correct, such a statement could hardly be impartial. However, at the time of McLane's trial, Canadian jurists played a very different role than they do today. Perhaps because of their fear of the French revolutionaires and the overwhelming Canadian population, most of the judges of the Lower Canadian Bench throughout the Revolutionary and Napoleonic Wars and until after the rebellions of 1837-1838, adhered to the philosophy of Sir Francis Bacon that the impartial application of the law was secondary to the duty of supporting the government. Greenwood, "The Treason Trial," 11-13; Greenwood, Legacies of Fear, 166-167.

303 Summation of Chief Justice William Osgoode on July 7, 1797, in 26 state Trials 721, 810-811. 
The jury then withdrew and deliberated for only twenty minutes. Upon its return, the clerk of the court asked if the jurors were all in agreement as to a verdict and, when they answered "yes," he then inquired "how say you - Is he [McLane] Guilty of the felony and high treason whereof he stands indicted, or Not Guilty?" The response was "Guilty." The Attorney General immediately moved for a judgment of death, but the defense objected and asked for four days to prepare a motion "to arrest the judgment" (i.e., to prevent McLane's execution as according to the law). The motion was denied after Attorney General sewell and Chief Justice Osgoode pointed out that while granting the request was the usual practice in a regular court, the practice under commissions of oyer and Terminer was to pronounce sentence instantly. With no other alternative, Pyke and Francklin then made their motions to arrest the judgment, arguing first that the applicability of the statute under which McLane was indicted was geographically limited to England and, second, that the indictment did not allege that McLane was a British subject nor a friendly alien when the acts of treason were committed. After a lengthy debate between the defense and prosecution, both motions were overruled. /304/

304 Inquiry of the clerk of the Arraigns on the Foreman of the Jury on July 7,1797 , in 26 State Trials 721,$811 ; 26$ state Trials 721, 811-824. 
McLane was asked if he had anything to say as to why the court should not proceed to pass the judgment of death upon him, but he indicated that he had nothing to add. The court clerk then demanded silence in the courtroom as chief Justice osgoode, at nine o'clock in the evening and wearing the traditional black hood, addressed the prisoner. After advising the defendant that he had received a fair trial, the judge exhorted Mclane to "employ the short time you have to live, in submitting yourself with humiliation and repentance to the supreme Ruler" and then pronounced the sentence of death. Mclane then "behaved as became his unhappy situation" and confessed that he was employed by Adet to deliver letters to "some disaffected gentlemen" and to hand out military commissions to those who would lead a rebelition in Lower Canada. As pursuant to a ruling of the court, the execution was carried out two weeks later on July 2lst. /305/

26 State Trials 721, 824-828; Pronouncement of Sentence of Death by Chief Justice William Osgoode on July 7, 1797, in 26 state Trials 721, 826; Greenwood, Legacies of Fear, 164; [Anonymous], The Trial, Condemnation and Horrid Execution of David M'Lean, 10-11.

The letters that Mclane admitted to carrying for Adet may have been those addressed to John Black and John Blackwood. See footnotes 139, 164, and 288 and accompanying text. 
CHAPTER XIII

CONCLUSION

In one sense, McLane's cause was not lost until the jury pronounced its verdict of guilty, but the fears amongst the British in Lower Canada of a French invasion of England itself, of an attack upon the colony, and of the vast Canadian population rising up in arms eliminated any chance that Mclane had to a fair trial. From the beginning, the colonial authorities were going to make an example of McLane to deter the activities of potential traitors and spies and the government and the court manipulated the legal system to guarantee a conviction. They bought incriminating testimony with promises of townships. They created a special court to try McLane. They placed individuals on the bench, the grand jury, and the jury who had a deep distrust (and even dislike or hatred) of Americans along with an uncompromising sense of loyalty and patriotism and a vested interest in maintaining the status quo in the colony. The laws regarding treason (at least as to the compassing of the monarch's death) were interpreted in an extremely broad fashion. They appointed as defense counsel two young and inexperienced attorneys who had strong connections with the senior prosecuting 
attorney and one of the judges on the bench and who were unlikely to buck the colonial establishment. They virtually instructed the jury to find a guilty verdict and they did not allow the defense lawyers the time they needed to prepare a motion to arrest the verdict. To use a cliche, Mclane was a "dead man" from the moment he was arrested.

But Mclane was not innocent. Not only are there the four receipts that he signed indicating payment for his services, but the testimony and pre-trial depositions give a consistent and logical story of espionage. Furthermore, McLane may not have been acting alone; Butterfield and Frichet were admitted accomplices, but from the "loose ends" found in the testimony and the despositions, there are strong indications that their involvement was much more extensive than they would have us believe and there is a possibility that Black may have had some involvement with McLane before that fateful day of May 10, 1797. But McLane was doomed once Ira Allen and the olive Branch were seized the previous october because, when that occurred, the French Directory decided to halt their plans for an invasion of Lower Canada, but they did not advise Adet of the decision. If the account of McLane's plan to seize the garrison at Quebec City, as testified to by Black, is accurate, then he surely would have been taken when the expected French fleet failed to appear. 
There are many questions that remain to be answered. For example, when did Mclane actually start working for the French? Was his trip into Montreal in August, 1796 his first visit to the city? Why did McLane approach the individuals that he did and who recommended Barnard and Chandonet to him? Where there others that McLane tried to enlist into his plans? What did McLane do in Montreal in August and september, 1796? Who was the French officer that, according to Frichet, was suppose to go to Quebec City instead of Mclane and who did Frichet guide into Lower Canada in 1796? What, if any, contact did Black have with McLane and Adet before May, 1797? But even if these questions are never answered, the times and trial of David McLane exemplify the French threat to Lower Canada in the 1790's as well as the extent of the fears of the British in the colony and the lengths to which they were willing to go to calm those fears. Mclane's trial is also a perfect example of how a government can manipulate a criminal trial under the English legal system, despite all of its perceived protections of the rights of the defendant, to ensure a conviction. And, finally, Mclane's story is one of irony because he was a guilty man who was hanged as a result of a rigged trial. 
[Anonymous]. The Trial, condemnation and Horrid Execution of David M'Lean, Formerly of Pennsylvania, for High Treason Against the British Government, at the city of Quebec, on the 21st day of July last, Who was hanged, drawn, quartered, and beheaded on the above day, with all the attendant circumstances of cruelty and barbarity. Windham, CT: No publisher Iisted, 1797.

[Anonymous, probably John Gilmary Shea]. "Trial and Execution of David McLane, an American, for High Treason, at Quebec in 1797." The Historical Magazine and Notes and Queries concerning the Antiquities, History and Biography of America $7: 5$ (May, 1863): 137-141.

Arnold, James N. Vital Records of Rhode Island, 1636-1850. First Series. Births, Marriages and Deaths: A Family Register for the People, 21 vols. Providence: Narragansett Historical Publishing Company, 1891-1912.

B[artlett], J.R.B. "An Account of the Trial, Conviction and Execution of David M'Lane, of Providence, Rhode Island, at Quebec in 1797 for the Alleged Crime of High Treason." in the Evening Bulletin (Providence, RI) 26 April 1873 (Supp.)

Baxter, Marion. Application for Membership to the National Society of the Daughters of the American Revolution. Application Accepted and Approved February 8, 1922. Copy in Possession of Claire Weidemier McKarns, Encinitas, California.

Black, Henry Campbell, Joseph R. Nolan, and M.J. Connolly. Black's Law Dictionary: Definitions of the Terms and Phrases of American and English Jurisprudence, Ancient and Modern. Fifth Edition. St. Paul: West Publishing Company, 1979.

Black, Henry Campbell, and others. Black's Law Dictionary: Definitions of the Terms and phrases of American and English Jurisprudence, Ancient and Modern. Sixth Edition. St. Paul: West Publishing Company, 1990. 
Braud, Pierre. "DeMiliiere: Vendee et Canada." February 2, 1991. Working Notes. In Possession of the state and Military Archives Programme, Manuscript Division, Historical Resources Branch, National Archives of Canada. Ottawa.

Brown, George W., and others, eds. Dictionary of Canadian Biography. Vols. 4-8. Toronto: University of Toronto Press, 1979-1985.

Brymner, Douglas. Report on Canadian Archives 1891 Being an Appendix to Report of the Minister of Agriculture (aka Public Archives of Canada 1891) ottawa:

S.E. Dawson, 1892 .

Buchanan, A. W. Patrick. The Bench and Bar of Lower Canada Down to 1850. Montreal: Burton's Limited, 1925.

Caron, Ivanhoe. Ia colonisation de la Province de Quebec: Les Cantons de L'Est, 1791-1815. Quebec: L'Action Sociale, 1927.

Chamberlain, Mildred M., ed. The Rhode Island 1777 Military Census. Baltimore: Genealogical Publishing Company, 1985.

Christie, Robert. A History of the late Province of Lower Canada, Parliamentary and Political, From the Commencement to the close of Its Existence as a Separate Province. Vol. 1. Montreal: Richard Worthington, 1866 .

Church of Jesus Christ of Latter Day Saints. Baptisms for the Dead, Book $H$, 1896-1897. Salt Lake Temple Records, Salt Lake City. Filmed by the Genealogical Society, salt Lake City: Microfilm Reel 183417.

- Baptisms for the Dead, Book 5K, 1934. Salt Lake Temple Records, Salt Lake city. Filmed by the Genealogical society, salt Lake city: Microfilm Reel 183551 .

- Baptisms for the Dead, Book 5N, 1935. Salt Lake Temple Records, Salt Lake City. Filmed by the Genealogical society, Salt Lake City: Microfilm Reel 183554 .

- Baptisms for the Dead, Book 6E, 1937-1938. Salt Lake Temple Records, Salt Lake City. Filmed by the Genealogical society, Salt Lake City: Microfilm Reel 183571 . 
- "Massachusetts: Dana, Catherine - Davis, Edmund." International Genealogical Index 1992. Microfiche 0-0559.

- "Massachusetts: Faunce, Elmina - Fest, Catherine." International Genealogical Index 1992. Microfiche 0-0572.

- "Massachusetts: McKenna, May - Merrick, Charles." International Genealogical Index 1992. Microfiche $0-0628$.

- "Rhode Island: Madsen, George - McAndrew, Ann." International Genealogical Index 1992. Microfiche $0-1417$.

City of Providence, Rhode Island. Index to Deeds, 16771872: Mortgages to 1845 In Possession of the Division of Archives and History, City Hall, Providence, Rhode Island.

- "Re: David McLane, \#A1673." Probate Proceedings. Book One. In Possession of the Division of Archives and History, City Hall, Providence, Rhode Island.

- Vital statistics. Book Five. In Possession of the Division of Archives and History, City Hall, Providence, Rhode Island.

Collections of the New York Historical Society for the year 1914: Revolutionary Muster Rol1s, 1775-1783. The John watts DePeyster Publication Fund Series. Vol. 47. New York: Privately Printed, 1916.

Cushing, Elmer. An Appeal Addressed to a Candid Publici And to the Feelings of Those Whose Upright Sentiment and Discerning Minds, Enable Them to "Weigh It in the Balance of the Santuary". Stanstead, Lower Canada (now Quebec): S. H. Dickerson, 1826.

Danforth, walter R. "Pictures of Providence in the Past, 1790-1820: The Reminiscences of Walter R. Danforth." Edited by Clarkson A. Collins, 3rd. Rhode Island History 10:3 (July, 1951): 85-96.

de Salaberry, col. Rene. "The First state Trial in Lower Canada." Women's Canadian Historical Society of ottawa: Transactions. 10 (1928): 136-146. 
Deschenes, Gaston, ed. Dictionnaire des parlementaires du Quebec: 1792-1992. Sainte-Foy, Quebec: Les Presses de L'Universite Laval, 1993.

Doughty, Arthur G., and Duncan A. McArthur, eds. Public Archives: Documents Relating to the Constitutional History of Canada, 1791-1818. Ottawa: C.H. Parmelee, Printer to the King's Most Excellent Majesty, 1914.

Flenley, R. "The French Revolution and French Canada." Chap. in Essays in Canadian History Presented to George Mackinnon Wrong for His Eightieth Birthday. Toronto: The Macmilian Company of Canada, Ltd., 1939.

Garrett, wilbur E., ed. Atlas of North America: Space Age portrait of a continent. Washington: National Geographic, 1985.

Goodrich, John E., ed. The state of Vermont: Rolls of the Soldiers in the Revolutionary War, 1775 to 1783 .

Rutland, VT: The Tuttle Company, 1904.

Greenwood, F. Murray. "The Development of a Garrison Mentality Among the English in Lower Canada, 17931811." Ph.D. diss., University of British Columbia, 1970 .

- "The Treason Trial and Execution of David McLane." Chap. in Glimpses of Canadian Legal History, eds. Dale Gibson and $W$. Wesley Pue, 1-13. Winnipeg: Legal Research Institute of the University of Manitoba, 1991.

- Legacies of Fear: Law, Politics and Ideology in Quebec/Lower Canada During the Period of the French Revolution (1784-1811). TMs [photocopy]. Original in possession of F. Murray Greenwood, white Rock, British Columbia. Published: October, 1993, by the Osgoode Society, Toronto: pg. 139-170, 300-306.

Heads of Families at the First census of the United states Taken in the Year 1790: Massachusetts. Washington: Government Printing officer, 1908: reprint, Baltimore: Genealogical Publishing Company, 1966.

Heads of Families at the First Census of the United states Taken in the Year 1790: Rhode Island. Washington: Government printing office, 1908; reprint, Baltimore: Genealogical Publishing Company, 1966. 
Heads of Families at the First Census of the United states Taken in the Year 1790: Vermont. Washington: Government Printing office, 1907; reprint, Baltimore: Genealogical Publishing Company, 1966.

Heads of Families at the Second Census of the United states Taken in the Year 1800: Vermont. Montpelier: Vermont Historical Society, 1938.

Heitman, Francis B. Historical Register of officers of the Continential Army during the war of the Revolution: April, 1775, to December, 1783. New, Revised, and Enlarged Edition. Washington: Rare Book shop Publishing Company, 1914.

Hemenway, Abby Maria. Vermont Historical Gazetteer, A Local History of All the Towns in the state: Civil Educational, Biographical, Religious, and Military. Vol. 4. Montpelier: Vermont Watchman and state Journal Press, 1882 .

Holbrook, Jay Mark. Vermont's First Settlers. Oxford, MA: Holbrook Research Institute, 1976.

- Rhode Island 1782 Census. Oxford, MA: Holbrook Research Institute, 1979.

- Vermont 1771 Census. Oxford, MA: Holbrook Research Institute, 1982.

Jeffers, J. Frith. History of Canada. History Primers. New and Enlarged Edition. Toronto: Canada Publishing Company, 1894.

Kennedy, Patricia. State and Military Archives Programme. Manuscript Division. Historical Resources Branch. National Archives of Canada. Ottawa, Ontario. August 11, 1993. Unrecorded Telephone Interview by Mark Thorburn.

Kingsford, W. The History of Canada. Vol. 7. Toronto: Rowsell and Hutchinson, 1894.

Landmann, George R. Adventures and Recollections of Colonel Iandmann, Late of the corps of Royal Engineers. Vol. I. London: Colburn and Company, 1852. 
Lavender, David. "Point of Genesis." In Fort Vancouver. David Lavender and Archie Satterfield. National Park Handbook Series. Washington: Division of Publications, National Park Service, U.S. Department of the Interior, 1981.

Le Jeune, Le R.P.I. Dictionnaire General de Biographie, Histoire, Litterature, Agriculture, Commerce, Industrie et des Arts, sciences, Moeurs, coutumes, Institutions politiques et Religieuses du Canada. Vol. 2. Ottawa: Universite D'ottawa, 1931.

Link, Eugene Perry. Democratic-Republican Societies, 17901800. Columbia studies in American Culture series. New York: Octagon Books, 1973.

Massachusetts soldiers and Sailors of the Revolutionary War. Vol. 10. Boston: Wright and Potter Printing Company, 1902 .

Maunsell, David, Lawton V. Crocker, and Dorman B.E. Kent. Gazetteer of Vermont Heritage. Chester, VT: The National Survey, 1966.

Mccorison, Marcus A., ed. Vermont Imprints, 1778-1820. Worcester, MA: American Antiquarian Society, 1963.

McGlenen, Edward W., ed. Boston Marriages from 1700 to 1809 (for 1752-1809). Baltimore, Genealogical Publishing Company, 1977 .

McKarns, Claire Weidemier. Personal Notes Regarding Her Ancestor, Thomas Butterfield. In Possession of Claire Weidemier McKarns, Encinitas, California.

Minnigerode, Meade. Jefferson, Friend of France, 1793: The career of Edmond Charles Genet, Minister plenopotentiary from the French Republic to the United States, as Revealed by His Private Papers, 1763-1834. New York: G.P. Putnam's Sons, 1928.

Nasatir, Abraham P. and Gary Elwyn Monell. French Consuls in the United States: A Calendar of Their Correspondence in the Archives Nationales. Washington: Library of Congress, 1967.

Neilson, J. The Trial of David M'Lane for High Treason before a special court of oyer and Terminer at Quebec on the 7th July 1797. Quebec: By the author, 1797. 
Ojala, Jeanne A. "Ira AIlen and the French Directory, 1796: Plans for the creation of the Republic of

United Colunbia." William and Mary Quarterly 36:3 (July, 1979): 436-448.

Ott, Joseph K. "Rhode Island Housewrights, Shipwrights, and Related Craftsmen." Rhode Island History 31:2-3

(May and August, 1972): 65-79.

Ouellet, Fernand. Lower Canada, 1791-1840: Social Change and Nationalism. Trans. by Patricia Claxton. Toronto: McClelland and stewart Itd., 1980.

Paterson, Thomas G, J. Gary Clifford, and Kenneth J. Hagan. American Foreign Policy: A History to 1914.

Third Edition. Lexington, MA: D.C. Heath and Company, 1988 .

Potter, Chandler E. The Military History of the state of New Hampshire, 1623-1861: Two Parts in one Volume. 1866-1868, Original Publisher Not Known; reprint, Baltimore: Genealogical Company, 1972.

Providence Gazette. 25 April 1795 - 12 March 1796.

Providence Gazette and Country Journal. 13 November 1790 19 July 1794 .

The Provincial statutes of Lower Canada, Enacted by the King's Most Excellent Majesty, by and with the Advice and consent of the Legislative council and Assembly of the said province, constituted and Assembled by Virtue of and under the Authority of an Act of the Parliament of Great Britain, Passed in the Thirty-First year of the Reign of our sovereign Lord George the Third by the Grace of God, of Great Britain, France and Ireland, King, Defender of the Faith, \&. Vols, 1-2. Quebec: William Vondenvelden, Printer to the King's Most Excellent Majesty, 1795-1797.

Quebec Gazette. 17 May 1785 - 25 september 1823.

Riddell, William Renwick. "Canadian state Trials: The King v. David McLane." Royal Society of Canada: Transactions, 3rd ser., 10 (May, 1916), sect. II: $321-337$.

Seltzer, Leon E., ed. The Columbia Iippincott Gazetteer of the World. Morningside Heights, NY: Columbia University Press, 1952. 
scott, walter s. The Canadian constitution Historically Explained. Toronto: The Carswell Company, Ltd., 1918.

Shea, John Gilmary. "David McLane, An American Executed for High Treason at Quebec in 1797." The New England Historical and Genealogical Register for the Year 186216 (October, 1862): 321-323.

Shortt, Adam, and Arthur G. Doughty, eds. Canadian Archives: Documents Relating to the constitutional History of Canada, 1759-1791. Parts 1 and 2 . Second and Revised Edition. Ottawa: J. de I. Tache, Printer to the King's Most Excellent Majesty, 1918.

Smith, Joseph Jencks, ed. Civil and Military List of Rhode Island, 1647-1800: A List of AII officers Elected by the General Assembly from the organization of the Legislative Government of the Colony to 1800. Providence: Preston and Rounds, Co., 1900.

Smith, Ronald D. "Agent McLane: Lone Revolutionary in Canada." The Rocky Mountain Social science Journal $12: 2$ (October, 1970): 73-82.

Stiness, John H. "A Century of Lotteries in Rhode Island, 1744-1844." Rhode Island Historical Tracts 2nd ser., 3 (1896): $1-123$.

Supplemental Information Card on Elmer Cushing. Received from "rt" on 24 janvier 1983. In Possession of the Dictionary of Canadian Biography, University of Toronto Press, Toronto, Ontario.

Tetu, Michel. "Quebec and the French Revolution." Canadian Parliamentary Review. 12:3 (Autumn, 1989): 2-6.

Tremaine, Marie. A Bibliography of Canadian Imprints: 17511800. Toronto: University of Toronto Press, 1952.

Vondenvelden, William. The Trial of David M'Lane for High Treason at the city of Quebec, in the Province of Lower-Canada on Friday, the Seventh day of July, A.D. 1797. Taken in Short-Hand, at the Trial. Quebec: BY the author ( $w$. Vondenvelden, Law Printer to the King's Most Excellent Majesty), 1797. 
"Trial of DAVID MACLANE for High Treason; before the court holden under a special Commission of Oyer and Terminer, at the city of quebec in the Province of Lower Canada, on Friday the 7th day of July: 37 GEORGE III. A.D. 1797." In Vol. 26 of A Complete Collection of state Trials and proceedings for High Treason and other Crimes and Misdemeanors from the Earliest Period to the Year 1783 , with Notes and other Illustrations: Complied by T.B. Howell, Esa. F.R.S. F.S.A. and Continued from the Year 1783 to the Present Time, by Thomas Jones Howell, 721-828. London: T.C. Hansard, 1819.

Wade, Mason. "Quebec and the French Revolution of 1789: The Missions of Henry Meziere." The Canadian Historical Review 16:4 (December, 1950): 345-368.

The French Canadians, 1760-1967.

Revised edition. Vol. 1. Toronto: Macmillan of Canada, Ltd., 1968.

Wallis, J.P. "Treason and Treason Felony." In Encyclopaedia of the Laws of England. Vol. 12. ed. A. Wood Renton. London: Sweet and Maxwell, 1898: 254-264.

Webster, T.S. "A New Yorker in the Era of the French Revolution: Stephen Thorn, Conspirator for a Canadian Revolution." New York Historical Society Quarterly $53: 3$ (1969): $251-272$.

Wilber, James Benjamin. Ira Allen, Founder of Vermont: 1751-1814. 2 vols. Boston and New York: Houghton Mifflin Company, 1928.

Williamson, Chilton. Vermont in euandary: 1763-1825. Montpelier: Vermont Historical Society, 1949. 